Aus dem Department für Nutztierwissenschaften

Abteilung Produktionssysteme der Nutztiere

\title{
Zusammenhang zwischen Bestands-, Gruppengröße und Indikatoren des \\ Tierwohls in der konventionellen Schweinemast
}

\author{
Dissertation \\ zur Erlangung des Doktorgrades \\ der Fakultät für \\ Agrarwissenschaften \\ der Georg-August-Universität Göttingen \\ vorgelegt von \\ Sophie Elise Katharina Meyer-Hamme \\ geboren in Sulingen, Niedersachsen
}

Göttingen, im Dezember 2015 
D 7

1. Referent: Prof. Dr. Dr. Matthias Gauly

2. Korreferent: Prof. Dr. Achim Spiller

Tag der mündlichen Prüfung: 11.02.2016 
Meinen Eltern 



\section{Inhaltsverzeichnis}

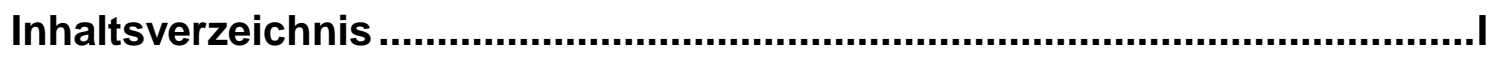

Verzeichnis der Abbildungen...............................................................II

Verzeichnis der Tabellen ........................................................................... IV

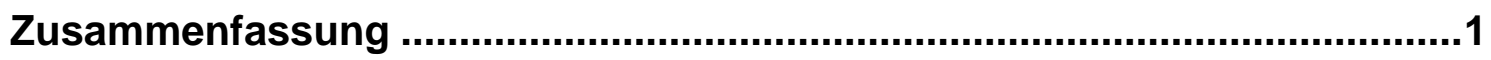

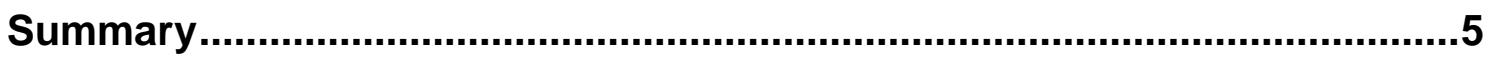

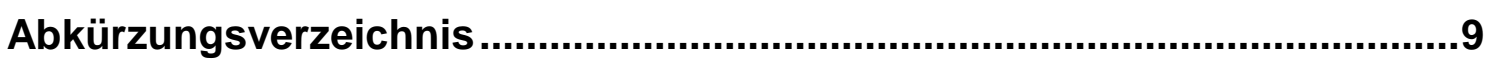

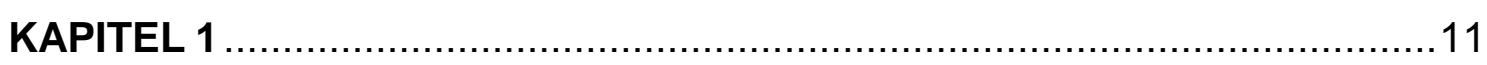

Allgemeine Einleitung

KAPITEL 2 .

\section{Literaturübersicht}

2.1 Entwicklung der Schweineproduktion in Deutschland

2.2 Problemfelder der konventionellen Schweinemast in Bezug zum

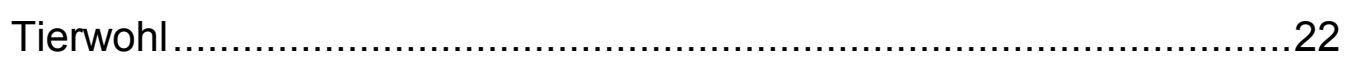

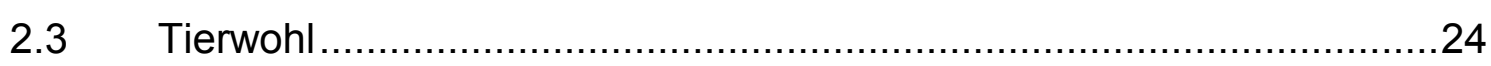

2.3.1 Gebräuchliche Begriffe und deren Definitionen ...................................24

2.3.2 Methoden zur Tierwohlbewertung - das Welfare Quality $®$ Protokoll

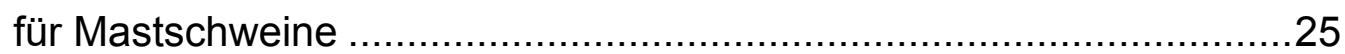

2.3.3 Zusammenhang zwischen Bestandsgröße und Tierwohl ....................32

2.3.4 Zusammenhang zwischen Gruppengröße und Tierwohl ......................38

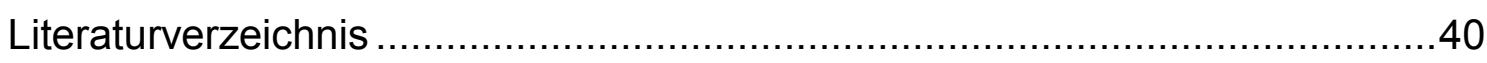

KAPITEL 3

Welfare Quality ${ }^{\circledR}$ assessment in intensive fattening pig farms in

Germany: Does herd size have an impact?

KAPITEL 4

Behavioural indicators of welfare in fattening pigs: Does herd size matter? KAPITEL 5 .

Does group size have an impact on welfare indicators in fattening pigs? KAPITEL 6

\section{Allgemeine Diskussion}

6.1 Einleitung. 
6.2 Zusammenhang zwischen Bestandsgröße und Tierwohl .................137

6.3 Zusammenhang zwischen Gruppengröße und Tierwohl ..................146

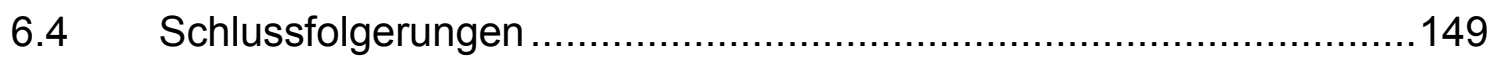

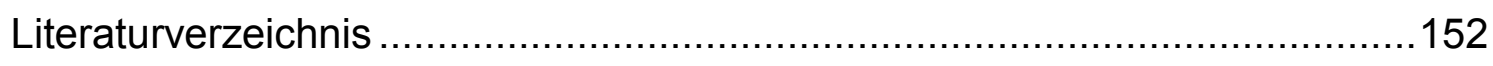




\section{Verzeichnis der Abbildungen}

\section{KAPITEL 2}

Abbildung 1: Entwicklung der Schweineproduktion in Deutschland (Eigene Darstellung nach Statistisches Bundesamt (2014)) 19

Abbildung 2: Entwicklung der Schweinebestände in Deutschland (Eigene Darstellung nach Statistisches Bundesamt (2014)) ............................... 20

Abbildung 3: Der Aggregierungsprozess von der Ebene der Indikatoren zum Gesamtscore (Welfare Quality®, 2009) 30

Abbildung 4: Theorien zum Zusammenhang Bestandsgröße und Tierwohl (WBA, 2015) 34

\section{KAPITEL 3}

Figure 1: Word chart presenting loadings on factor 1 and 2 of the Principal Component Analysis for the twelve different criteria scores for small (black), medium (dark grey) and large (light grey) farms. 69

\section{KAPITEL 4}

Figure 1: Word chart presenting loadings on factor 1 and 2 of the Principal Component Analysis for the twelve different criteria scores for small (black), medium (dark grey) and large (light grey) farms (ac = active, re = relaxed, fe = fearful, ag = agitated, $\mathrm{ca}=$ calm, $\mathrm{co}=$ content, te $=$ tense, en = enjoying, $\mathrm{fr}=$ frustrated, so $=$ sociable, bo $=$ bored, $\mathrm{pl}=$ playful, po = positively occupied, Is = listless, IV = lively, in = indifferent, ir = irritable, ai = aimless, ha = happy, di = distressed) 


\section{Verzeichnis der Tabellen}

\section{KAPITEL 2}

Tabelle 1: Einteilung verschiedener Methoden zur Erfassung des Tierwohls

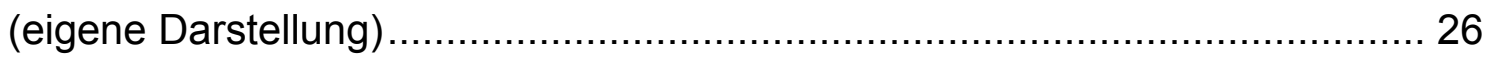

Tabelle 2: Aufbau des Welfare Quality® Protokolls für Mastschweine (verändert nach Temple et al. (2011))

Tabelle 3: Zusammenhang zwischen dem Vorkommen von Salmonellosen, Pneumonie, Influenza sowie der Prävalenz bestimmter Verhaltensweisen und der Bestandsgröße (eigene Darstellung)

\section{KAPITEL 3}

Table 1: Principles, criteria and indicators of the Welfare Quality ${ }^{\circledR}$ assessment protocol

Table 2: Indicators of the Welfare Quality ${ }^{\circledR}$ assessment protocol and their scoring

Table 3: Scores (least square means (LSM), standard error (SE), range) of the principles (bold) and criteria of the Welfare Quality ${ }^{\circledR}$ protocol, separated by farm size (small: $<1,500$ pigs/farm, medium: 1,500 to 3,000 pigs/farm and large: $>$ 3,000 pigs/farm)

\section{KAPITEL 4}

Table 1: Qualitative behaviour assessment of the Welfare Quality ${ }^{\circledR}$ assessment protocol for growing pigs expressed in $\mathrm{mm}$ and the standard division of the scale $(0-125 \mathrm{~mm}$ ) separated by farm size (small: $<1,500$ pigs/farm, medium: 1,500 to $3,000 \mathrm{pigs/farm}$ and large: $>3,000 \mathrm{pigs} /$ farm)

Table 2: Spearman Rank Correlation Coefficients for Principle Component 1 (Factor 1 ) and 2 (Factor 2) between the three different farm size categories .. 94 Table 3: Effect of farm size (small: $<1,500$ pigs/farm, medium: 1,500 to 3,000 pigs/farm and large: $>3,000$ pigs/farm) on the variables of the social and exploratory behaviour (LSMeans $\pm \mathrm{SE}$ ) 95 


\section{KAPITEL 5}

Table 1: Distribution (in \% of pens) of floor type (fully-slatted and partly slatted), space allowance (legally justified and not legally justified) and live weight group $(1,2$ and 3$)$ in dependence of three different group sizes (small, medium and large) evaluated in 600 pens for growing pigs.

Table 2: Prevalence (\%) of the animal-based measures of the Welfare Quality $®$ assessment protocol for growing pigs evaluated in 600 pens 119

Table 3: Prevalence (\%) (standard error) of selected animal-based measures of the Welfare Quality ${ }^{\circledR}$ protocol for growing pigs separated by group size (small, medium and large) and live weight group (1,2 and 3) evaluated in 600 pens.120 Table 4: Prevalence (\%) (standard error) of the social and exploratory behaviour separated by group size (small, medium and large) and live weight group (1,2 and 3) evaluated in 600 pens. 122

Table 5: Probability of occurrence of a panic response to the observer depending on group size (small, medium and large) evaluated in 600 pens.. 123 


\section{Zusammenfassung}

In der Vergangenheit hat der Tierschutzgedanke in der Gesellschaft zunehmend an Bedeutung gewonnen. Viele Verbraucher verbinden moderne landwirtschaftliche Nutztierhaltung primär mit hohen Tierzahlen auf engem Raum und daraus vermeintlich resultierenden Defiziten im Tierschutz. Der Begriff „Massentierhaltung“ wurde zum Synonym für wenig tiergerechte Haltungssysteme. Er wird vor allem in den Medien stark diskutiert und ist eindeutig negativ besetzt. Neben der Bestandsgröße steht besonders die Gruppengröße in der Kritik. Die Kenntnisse über die kausalen Beziehungen zwischen Tierwohl/Tierverhalten und konventioneller Tierhaltung bzw. Bestands- und Gruppengrößen sind dabei ausgesprochen gering, und zwar sowohl auf theoretischer wie auf empirischer Ebene. In der Literatur vorhandene Studien beziehen lediglich einzelne Teilaspekte des Tierschutzes und nur bestimmte Tierarten in ihre Auswertungen mit ein. Insbesondere für die Mastschweinehaltung, die in der aktuellen Tierschutzdebatte besonders im Fokus steht, gibt es nur wenige wissenschaftliche Untersuchungen, die sich mit dem Einfluss der Bestands- bzw. Gruppengröße auf das Tierwohl beschäftigen. Aus diesem Grund sollten im Rahmen der vorliegenden Studie belastbare Aussagen über den Zusammenhang von Tierwohlindikatoren und der Bestands- sowie Gruppengröße abgeleitet werden. Die Bestandsgröße wurde definiert als die gesamte Anzahl Tiere einer Nutzungsrichtung an einem Standort. Die Gruppengröße beschreibt die Anzahl Schweine pro Bucht bei konstantem Platzangebot pro Tier. Darüber hinaus sollte Auskunft über die Tiergerechtheit konventioneller Schweinemastbetriebe gegeben werden. Dies könnte zu einer wesentlichen Versachlichung der gesellschaftlichen Diskussion beitragen.

Insgesamt wurden 60 Schweinmastbetriebe mit Hilfe des Welfare Quality®Protokolls für Schweine bewertet. Unter Berücksichtigung der Betriebsgrößenentwicklung in der deutschen Schweineproduktion und in Anlehnung an die Einteilung der Betriebe nach dem BundesImmissionsschutzgesetz (BImSchG, 2013) wurden die untersuchten Betriebe in 
drei Bestandsgrößen-Kategorien (jeweils 20 Betriebe/Kategorie) eingeteilt: 1) klein $=<1.500$ Mastplätze, 2) mittel $=1.500$ bis 3.000 Mastplätze und 3) groß $=$ 3.000 Mastplätze. Es wurden nur konventionell arbeitende Betriebe mit den am weitesten verbreiteten Haltungsverfahren (Planbefestigter Boden, Zwangsbelüftung, Automatische Fütterung) in die Untersuchungen einbezogen. Die teilnehmenden Betriebe hielten durchschnittlich 2.641 Schweine, wobei die Zahl der Mastplätze zwischen 260 und 11.000 variierte. Die Mehrheit der Betriebe $(92 \%)$ hielt die Tiere auf Voll- und $8 \%$ auf Teilspaltenböden. Die Gruppengröße variierte von 10 bis 350 Schweinen pro Bucht (Mittelwert: 20 Schweine/Bucht, Median 16 Schweine/Bucht). Um den Einfluss der Gruppengröße auf das Tierwohl betrachten zu können, wurden drei Gruppengrößen-Kategorien definiert: klein: $<15$ Schweine/Bucht, $\mathrm{n}=207$ Buchten; mittel: 15 bis 30 Schweine/Bucht, $\mathrm{n}=257$; groß: $>30$ Schweine/Bucht, $\mathrm{n}=136$. Im Durchschnitt betrug das Platzangebot 0,83 $\mathrm{m}^{2} /$ Schwein $\left(0,31 \mathrm{~m}^{2}\right.$ bis $\left.2,5 \mathrm{~m}^{2} / \mathrm{Sch} w e i n\right)$.

Das Welfare Quality ${ }^{\circledR}$ Protokoll ist ein vornehmlich tierorientiertes Indikatorensystem, das der umfassenden Beurteilung des Wohlergehens von Nutztieren auf Betriebsebene dient. Es beinhaltet vier verschiedene Stufen, über die aus den ursprünglich 34 Indikatoren in einem hierarchischen Aggregierungsprozess 12 Kriterien, 4 Grundsätzen und schließlich ein einziger Gesamtscore gebildet wird. Die Betriebe wurden auf dieser Basis als „ausgezeichnet“, „verbessert“, „akzeptabel“ oder „,nicht klassifiziert“ eingestuft. Die drei Bestandsgrößen- sowie Gruppengrößen-Kategorien wurden anhand der Mittelwerte aus der Tierwohl-Bewertung des Protokolls miteinander vergleichen. Der Betrieb wurde als zufälliger Effekt berücksichtigt.

Annähernd $80 \%$ der Betriebe wurden als "verbessert" klassifiziert; alle anderen Betriebe als „akzeptabel“. Grundsätzlich ist das Tierwohl-Niveau damit als eher niedrig einzustufen. Die Bestandsgröße hatte keinen signifikanten Effekt auf die Ausprägung des Gesamtscores. Auf der Grundsatz- und auf der Kriterienebene konnten keine signifikanten Unterschiede zwischen den BestandsgrößenKategorien abgesichert werden. Der Grundsatz "Gute Fütterung" erzielte mit Abstand die höchste Punktzahl, obwohl das dazugehörige Kriterium 
„Abwesenheit von Durst", aufgrund teilweise erheblicher Mängel bei der Wasserversorgung nicht die volle Punktzahl erreichte. Das Kriterium "Liegekomfort" des Grundsatzes "Gute Haltung" wird mit Hilfe des Verschmutzungsgrades und dem Vorkommen von Bursitis bewertet. Im Mittel waren auf den 60 Betrieben, unabhängig von der Bestandgröße, 34,7\% der Schweine von moderater Bursitis betroffen. Damit war Bursitis der am häufigsten vorkommende Indikator. Der Verschmutzungsgrad der Tiere nahm dagegen signifikant mit steigender Bestandsgroße zu $(P<0,05)$ : in kleinen Betrieben betrug der Anteil moderat verschmutzter Tiere 10,7\%, in mittleren $14,7 \%$ und in großen Beständen 20,6\%. Hierbei ist das Fütterungssystem als möglicher Einflussfaktor zu diskutieren. Der Score für das Kriterium „Bewegungsfreiheit" betrug im Durchschnitt 72 von 100 erreichbaren Punkten. Unter Berücksichtigung der Tierschutz-Nutztierhaltungsverordnung (2006) wurde festgestellt, dass etwa $40 \%$ der Buchten überbelegt waren.

Der Grundsatz "Gute Gesundheit" erzielte mit durchschnittlich 29,1 von 100 Punkten den schlechtesten Wert aller Grundsätze. Das dazugehörige Kriterium "Abwesenheit von Verletzungen“ bezieht unter anderem den Indikator Wunden ein. Mit einem Durchschnitt von 10,5\% moderat verwundeten Schweinen über alle 60 Betriebe ist der Anteil vergleichsweise hoch. Die Schlachtbefunde fließen in das Kriterium „Abwesenheit von Krankheiten“ ein. Der Anteil Tiere mit veränderten Lungen war in kleinen Betrieben $(4,2 \%)$ tendenziell geringer als in mittleren (11,6\%) und größeren Betrieben (10,7\%). Bei dem Schwänzekupieren und Kastrieren der Ferkel wurde kein Anästhetikum verwendet. Dadurch erzielte das Kriterium „Abwesenheit von Schmerzen“ eine geringe Punktzahl.

Der Grundsatz „Artgemäßes Verhalten“ erreichte im Schnitt ebenfalls nur einen geringen Score von knapp über 30 von 100 Punkten. Ursächlich hierfür waren Defizite beim Erkundungsverhalten (Kriterium "Sonstiges Verhalten“) und die schlechte Bewertung des "emotionalen“ Zustandes der Tiere. Intensive Haltungssysteme werden oft hinsichtlich der mangelnden Ausübung von arttypischen Normalverhalten kritisiert.

Aus den Ergebnissen lässt sich schlussfolgern, dass die Bestandsgröße als Indikator für unzureichendes Wohlergehen nicht geeignet ist. Eine hohe Anzahl 
an Mastschweinen pro Bestand deutet nicht automatisch auf eine niedrige Tierwohlbewertung hin.

Hinsichtlich des Zusammenhangs zwischen den drei GruppengrößenKategorien und ausgewählten Indikatoren des Welfare Quality ${ }^{\circledR}$ Protokolls wurde festgestellt, dass die Gruppengröße einen signifikanten Effekt auf den Verschmutzungsgrad der Schweine $(P<0,05)$ hat. In der größten Gruppengrößen-Kategorie (15,8\%) waren signifikant mehr Tiere moderat verschmutzt als in der kleinen Gruppengrößen-Kategorie (10,4\%). Der Anteil moderat verwundeter Schweine nahm ebenfalls mit steigender Gruppengröße signifikant zu. In der größten Gruppengrößen-Kategorie (16,3\%) war der Anteil signifikant höher als in der mittleren (11,3\%) sowie der kleinen GruppengrößenKategorie (8,5\%). Sowohl die Indikatoren Verschmutzungsgrad und Verwundung stellen wichtige Parameter bezüglich tiergerechter Haltungssysteme da. Das Vorkommen von Schweinen mit moderater Bursitis wurde dagegen nicht von der Gruppengröße beeinflusst $(P>0,5)$. Allerdings wurde in großen Gruppen signifikant häufiger eine gute Mensch-Tier-Beziehung beobachtet. Damit war keine der untersuchten Gruppengrößen-Kategorien bezüglich der Indikatoren des Welfare Quality® Protokolls konsistent überlegen. Vielmehr scheint die Bedeutung der Gruppengröße, ebenso wie die der Bestandsgröße, hinsichtlich des Wohls der Tiere überschätzt zu sein. Gleichzeitig muss allerdings festgestellt werden, dass die Gesamtsituation u.a. auf Grundlage der erfassten Prävalenzen der Technopathien als unbefriedigend bezeichnet werden muss. Die Diskussion um Tierschutz und Tierwohl muss weiter geführt werden. Es müssen andere Faktoren wie z.B. das Management oder das Haltungssystem in den Fokus der Untersuchungen genommen werden, um das Tierwohl auf den Betrieben nachhaltig zu verbessern. 


\section{Summary}

Animal welfare became a significant issue in the society throughout the past decades. Many consumers tend to combine modern agricultural livestock farming primarily with a high number of animals on a confined space and consequently shortcomings when it comes to animal welfare. The term "intensive livestock farming" became a synonym for less animal-friendly husbandry and is discussed in the media under a rather negative light. In addition to the herd size, it is the size of the group that stands particularly under pressure. At the same time, the knowledge about the causal relationships between animal welfare and conventional livestock farming or the size of a herd or group is low, on a theoretical level as well as on the empirical one. Moreover, studies based on available literature do only include partial aspects of animal welfare and only certain animal species in their analyses. The current debate also focusses on fattening pig farms but only a few scientific studies cover the influence of herd- and group sizes on animal welfare.

Therefore, the present study should derive a reliable statement about the connection of animal welfare indicators and the herd- and group size. The herd size was defined as the total number of animals of one field of usage at one location. The group size describes the number of pigs per pen at constant space supply per animal. Furthermore, animal welfare in conventional fattening pig farms need to be considered. This may lead to a general objectification throughout discussions in the society.

Overall, 60 pig fattening farms were evaluated with the support of the Welfare Quality $\circledast$ Protocol for pigs. In due consideration of the development of farms in the German pig production and in accordance with the classification of pig farms by the German Federal Pollution Protection Act (2013), the assessed farms were categorized in the three farms size categories (20 farms/category): small $=<1.500$ pigs $/$ farm, 2) medium $=1.500$ to 3.000 pigs $/$ farm and 3$)$ large $=$ 3.000 pigs/farm. Only conventional fattening pig farms with the most prevalent husbandry system (concrete floors, forced ventilation systems, automatic feeding systems) were included in this study. The participating farms hold an 
average amount of 2.641 pigs, although the number of fattening places varies between 260 and 11.000. The majority of farms (92\%) keeps animals on fulland $8 \%$ on partly slatted floors. The group size varies between 10 to 350 pigs per pen (average value: 20 pigs/pen, median: 16 pigs/pen). To analyse the influence of the group size on animal welfare, three group size categories were defined: small: 15 pigs/pen, $n=207$ pens, medium: 15 to 30 pigs/pen, $n=257$; large $=>30$ pigs/pen, $n=136$. The average pen size capacity covers $0.83 \mathrm{~m}^{2}$ per pig (range 0.31 to $2.5 \mathrm{~m}^{2}$ per pig).

The Welfare Quality ${ }^{\circledR}$ Protocol is an animal orientated indicator system that serves the comprehensive evaluation of animal welfare on livestock on the farm level. It includes four different steps that form out of the original 34 indicators, in a hierarchical aggregation process 12 criteria, 4 principles and finally one single overall assessment. The farms were classified on this fundament as "excellent", "enhanced", "acceptable" or "not classified". The tree herd size-categories as well as group size- categories were compared to each other with reference to the averages in animal welfare evaluation from the protocol. The farm served as random effect.

Almost $80 \%$ of the evaluated farms were classified as "enhanced", all others as "acceptable". Generally speaking, the overall welfare level of the evaluated farms hast to be considered as low. The herd size had no significant effect on the characteristics of the overall assessment. Principle- and criteria level could not prove significant differences between the herd size categories. The principle "good feeding" reached by far the highest score, even though the appropriate criteria "absence of thirst", due to partly deficiencies in water supply, did not reach the highest achievable points. The criteria "comfort around resting" of the principle "good housing" was assessed with the help of the indicators manure on the body and bursitis. On average, $34.7 \%$ of the pigs on 60 farms, independent of the herd size, were affected with moderate bursitis. Thereby bursitis was the most common measure on the farms. The prevalence of manure on the pigs increased according the herd size $(P<0.05)$ : the proportion of moderate soiled animals came up to $10.7 \%$ at smaller farms, in the middle $14.7 \%$ and in larger farms $20.6 \%$. Moreover, the feeding system can be 
discussed as a potential factor of influence. The criteria "ease of movement" reached a score of 72 out of 100 possible points in average. Considering the German Farm Animal Welfare Regulations (2006), 40\% of the pens were overcrowded.

Among all principles, "good health" was scored worst with an average of 29.1 of 100 points. The associated criteria "absence of injuries" included among others the indicator wounds on the body. With an average of $11 \%$ wounded pigs on all 60 farms, the proportion is comparable high. The results of the slaughterhouse belong to the criteria "absence of diseases". The incidence of pneumonia was in tendency lower in small herds (4.2\%) than in medium (11.6\%) and large herds $(10.7 \%)$. Tail-docking and castration of the piglets no anaesthetic was used. Thus the criteria "absence of pain" was scored worse.

The principle "appropriate behaviour" reached also a low score with 30 out of 100 points. This was mainly due to deficits for exploratory behaviour (criteria "expression of other behaviours") and the worse evaluation of the emotional state of the animals. Intensive systems are often criticised with respect to species-specific behaviour.

The results confirm that the herd size is not adequate as an indicator for insufficient well-being. A high number of pigs per farm are not correlated to a worse assessment of animal welfare.

Regarding the relationship between the group size-categories and selected indicators of the Welfare Quality ${ }^{\circledR}$ Protocol, it was determined, that the group size has a significant effect on the indicator soiled pigs $(P<0.05)$. In the largest group size-category $(15.8 \%)$ more pigs were significantly soiled as in the smallest group size-category (10.4\%). The prevalence of moderate wounded pigs also increased significantly with a growing group size. In the largest group size-category $(16.3 \%)$ the proportion was significantly higher than in the middle $(11.3 \%)$ and in the smallest group size-category (8.5\%). The indicator manure on the body as well as the indicator wounded pigs represent important indicators concerning animal-friendly husbandry systems. The prevalence of bursitis was not affected by the group size $(P<0.05)$. On the contrary, in large group sizes a better human-animal relationship was more often observed. In 
conclusion, none of the evaluated group sizes with respect to the indicators of the Welfare Quality® Protocol proved to be superior to others. It is more appropriate that the importance of the group size, as well as the herd size, with regard to animal welfare seems to be overestimated. At the same time, the overall situation has to be considered as unsatisfying, based on the detected prevalence's of technopathies. The discussion about animal protection and animal welfare has to be continued. Other factors like the management or husbandry system should be taken into the focus of further studies to improve sustainable animal welfare on farms 


\section{Abkürzungsverzeichnis}

BHZP German federal hybrid breeding program

BImSchG Bundesimmissionsschutzgesetz

Bspw. Beispielweise

bzgl. bezüglich

bzw. beziehungsweise

ca. circa

$\mathrm{cm} \quad$ Centimetre/Zentimeter

EFSA European Food Safety Authority

e.g. For example, abbreviation of Latin 'exempli gratia'

et al. and others/und andere, abbreviation of Latin 'et alii'

etc. and the rest, abbreviation of Latin 'et cetera'

EU Europäische Union

e.V. Eingetragener Verein

evtl. eventuell

FAO Food and Agriculture Organization of the United Nations

FAWC Farm Animal Welfare Committee

g Gram

i.e. that is to say/das heißt, abbreviation of Latin 'id est'

ISN Interessengemeinschaft Norddeutscher Schweinhalter

e.V.IAssociation of Pig Farmers in Germany

$\mathrm{kg} \quad$ Kilogram

LSM least square means

$\mathrm{m}^{2} \quad$ square metre(s)/Quadratmeter

Max Maximum

$\min \quad$ minute(s)

Min Minimum

$\mathrm{mm} \quad$ Millimeter

MS Mastschwein

n Anzahl

No./Nr. Number/Nummer 
P/p Probability/Wahrscheinlichkeit

PCA Principle Component Analysis

PIC Pig Improvement Company

QBA Qualitative Behaviour Assessment

RS Rank Correlation Coefficients

S. siehe

SAS Statistical Analysis System

SE standard error

TierSchG Tierschutzgesetz

TierschNutztV Tierschutz-Nutztierhaltungsverordnung

u.a. unter anderem

v.a. vor allem

vgl. Vergleich

vs. versus

WBA Wissenschaftlicher Beirat für Agrarpolitik, Ernährung und gesundheitlichen Verbraucherschutz

WQP Welfare Quality ${ }^{\circledR}$ Assessment Protokoll für Mastschweine

z.B. zum Beispiel 


\section{KAPITEL 1}

Allgemeine Einleitung 


\section{$1 \quad$ Allgemeine Einleitung}

Seit einigen Jahrzehnten kann eine zunehmende Entfremdung der Bevölkerung von der Landwirtschaft im Allgemeinen und zur Nutztierhaltung im Speziellen beobachtet werden (Hirschfelder, 2005; Kayser et al., 2011). Gleichzeitig herrscht auf Seiten der Bürger eine wachsende Besorgnis über die veränderten Produktionsbedingungen in der landwirtschaftlichen Nutztierhaltung (Vanhonacker et al., 2010), Tierschutz und Tierwohl gewinnen an Bedeutung (Fraser, 2009). Viele Verbraucher verbinden moderne Tierhaltung primär mit hohen Tierzahlen auf engem Raum und daraus vermeintlich resultierenden Defiziten im Tierschutz (Von Alvensleben, 2003). Nicht nur die möglichst weitgehende Abwesenheit von Schmerzen, Leiden und Schäden, sondern auch andere Aspekte des Tierwohls werden verstärkt in den Fokus der gesellschaftlichen Diskussion gerückt. So wird die Sicherung des Wohlbefindens, das das Erleben positiver Emotionen und die Ausübung des Normalverhaltens einschließt, zunehmend wichtiger (Van de Weerd \& Day, 2009; WBA, 2015).

In der öffentlichen Diskussion wird außerdem vielfach ein enger Zusammenhang zwischen der Größe von Tierhaltungsbetrieben und dem Tierschutzniveau hergestellt. Der Begriff "Massentierhaltung" wurde in dieser Debatte zum Synonym für wenig tiergerechte Haltungssysteme. Er wird vor allem in den Medien stark diskutiert und ist eindeutig negativ konnotiert (McCarty, 2005). Eine klare Definition dieses Begriffes existiert bisher jedoch nicht. Die Kenntnisse über die kausalen Beziehungen zwischen Tierschutz und konventioneller Tierhaltung bzw. Bestandsgrößen sind sowohl auf theoretischer als auch auf empirischer Ebene ausgesprochen verbesserungswürdig. Wissenschaftlich belastbare Ergebnisse zu möglichen Zusammenhängen zwischen Bestandsgrößen in der Tierhaltung und dem Tierwohl sowie dem Tierverhalten gibt es kaum. In der Literatur vorhandene Studien beziehen lediglich einzelne Teilaspekte und nur bestimmten Tierarten (z.B. Legehennen, Milchkühe) in ihre Auswertungen mit ein. Insbesondere für die Mastschweinehaltung, die in der aktuellen Tierschutzdebatte besonders im 
Fokus steht, gibt es nur wenige wissenschaftliche Untersuchungen zum Einfluss der Bestandsgröße auf das Tierwohl.

Neben der Bestandsgröße steht auch die Gruppengröße in der Kritik (Schröder \& McEachern, 2004; Vanhonacker et al., 2009; Velarde et al., 2015). Weitestgehend unklar ist in der öffentlichen Diskussion, ob Gruppen-, Buchten-, Abteil-, Stall-, Bestands- oder Unternehmensgröße betrachtet werden, wobei die Begrifflichkeiten nicht klar benannt bzw. definiert werden. Umfassende Studien wurden auch hier noch nicht angegangen. Während Wolter et al. (2001) und DeDecker (2003) Untersuchungen zum Zusammenhang von Gruppengröße/Besatzdichte und Produktivität durchführten, ist der Zusammenhang zwischen Gruppengröße und Tierwohl kaum untersucht. Die wenigen Studien (McGlone \& Newby, 1994; Samarakone \& Gonyou, 2008; Averós et al., 2010) betrachten auch in dieser Debatte vorwiegend nur einzelne Teilaspekte (z.B. Mortalität, Morbidität, Schwanzbeißen).

Voraussetzung einer umfassenden Bewertung des Tierwohls auf den Betrieben ist eine gültige, praktikable und zuverlässige Beurteilungsmethode. In der Vergangenheit wurden zahlreiche Systeme zur Bewertung der Tiergerechtheit auf Betriebsebene vorgeschlagen. Sie lassen sich in umweltbezogene, tierbezogene und integrative Konzepte einteilen. Bisher konnte sich jedoch kein einziges dieser Beurteilungssysteme dauerhaft als anerkannter Standard etablieren. Eine vergleichsweise neue Methode zur Beurteilung des Tierwohls auf Betriebsebene ist das Welfare Quality® Protokoll (Welfare Quality®, 2009). Das Welfare Quality® Projekt war ein von der Europäischen Union im Zeitraum von 2004 bis 2009 gefördertes Projekt, das sich zum Ziel gesetzt hatte, die Tiergerechtheit innerhalb der Lebensmittelkette nachhaltig zu verbessern (Canali \& Keeling, 2009) und einen einheitlichen europäischen Standard zu etablieren (Blokhuis, 2008). Vor dem Hintergrund eines wachsenden gesellschaftlichen Interesses an tiergerechten Haltungssystemen wurde diese Maßnahme von der EU initiiert, um den Wünschen der Bevölkerung nach verbesserten Haltungssystemen für Nutztiere entgegen zu kommen (Miele et al., 2011). Das Welfare Quality ${ }^{\circledR}$ Protokoll ist ein vornehmlich tierorientiertes Indikatorensystem, das der umfassenden Beurteilung des Wohlergehens von 
Nutztieren auf Betriebsebene dient. Es findet gegenwärtig in der Wissenschaft in allen an der Tierhaltung interessierten Abteilungen die größte Aufmerksamkeit (Blokhuis et al., 2013).

Anhand der vorliegenden Studie

1) sollen Aussagen zur Tiergerechtigkeit konventioneller Schweinemastbetriebe in Abhängigkeit von der Bestandsgröße gegeben werden und eine Einstufung der Betriebe hinsichtlich ihres Tierwohlniveaus ermöglicht werden (Kapitel 3),

2) soll neben dem Einfluss der Bestandsgröße auf das Tierwohl außerdem deren Effekt auf das Tierverhalten (Erleben positiver Emotionen) untersucht werden (Kapitel 4),

3) soll der Zusammenhang zwischen Gruppengröße und ausgewählten Tierwohlindikatoren des Welfare Quality ${ }^{\circledR}$ Protokolls beschrieben werden (Kapitel 5).

In der abschließenden Diskussion werden die Effekte und Zusammenhänge von Bestands- und Gruppengröße auf Tierwohl gemeinsam diskutiert und Schlussfolgerungen abgeleitet (Kapitel 6). 


\section{Literaturverzeichnis}

Averós X., Brossard L., Dourmad J.-Y., de Greef K.H., Edge H.L., Edwards S.A. \& Meunier-Salaün M.-C. 2010. A meta-analysis of the combined effect of housing and environmental enrichment characteristics on the behaviour and performance of pigs. Applied Animal Behaviour Science 127: 73-85

Blokhuis H. 2008. International cooperation in animal welfare: the Welfare Quality $\AA^{8}$ project. Acta Veterinaria Scandinavica 50: 10-18

Blokhuis H., Jones B., Veissier I. \& Miele M. 2013. Assessing and improving farm animal welfare: the way forward. In Improving farm animal welfare Science and society working together: the Welfare Quality approach, Wageningen Academic Publishers Gelderland, Netherlands, 215-222

Canali E. \& Keeling L. 2009. Welfare Quality® project: from scientific research to on farm assessment of animal welfare. Italian Journal of Animal Science 8: 900-903

DeDecker J.M.E., Bradley F. Wolter, Brendan P. Corrigan, Stanley E. Curtis, Gilbert R. Hollis 2003. The effect of group size/floor-space allowance on pig performance in a wean-to-finish production system. Swine Research Reports - 2003

Fraser D. 2009. Assessing animal welfare: different philosophies, different scientific approaches. Zoo Biology 28: 507-518

Hirschfelder G. 2005. Europäische Esskultur - Geschichte der Ernährung von der Steinzeit bis heute. Campus Verlag, Frankfurt a. M., 1-328

Kayser M., Böhm J. \& Spiller A. 2011. Zwischen Markt und Moral - Wie wird die deutsche Land- und Ernährungswirtschaft in der Gesellschaft wahrgenommen. In Schriften der Gesellschaft für Wirtschafts- und Sozialwissenschaften des Landbaues e.V., 329-341 
McCarty R. 2005. Consumers aware of factory farming; term creates negative impression Research Briefs: 51-52

McGlone J. \& Newby B. 1994. Space requirements for finishing pigs in confinement: behavior and performance while group size and space vary. Applied Animal Behaviour Science 39: 331-338

Miele M., Veissier I., Evans A. \& Botreau R. 2011. Animal welfare: establishing a dialogue between science and society. Animal Welfare 20: 103-117

Samarakone T.S. \& Gonyou H.W. 2008. Productivity and aggression at grouping of grower-finisher pigs in large groups. Canadian Journal of Animal Science 88: 9-17

Schröder M.J.A. \& McEachern M.G. 2004. Consumer value conflicts surrounding ethical food purchase decisions: a focus on animal welfare. International Journal of Consumer Studies 28: 168-177

Van de Weerd H.A. \& Day J.E.L. 2009. A review of environmental enrichment for pigs housed in intensive housing systems. Applied Animal Behaviour Science 116: 1-20

Vanhonacker F., Verbeke W., Van Poucke E., Buijs S. \& Tuyttens F.A.M. 2009. Societal concern related to stocking density, pen size and group size in farm animal production. Livestock Science 123: 16-22

Vanhonacker F., Van Poucke E., Tuyttens F. \& Verbeke W. 2010. Citizens' Views on Farm Animal Welfare and Related Information Provision: Exploratory Insights from Flanders, Belgium. Journal of Agricultural and Environmental Ethics 23: 551-569

Velarde A., Fabrega E., Blanco-Penedo I. \& Dalmau A. 2015. Animal welfare towards sustainability in pork meat production. Meat Science 109: 13-17 
Von Alvensleben R. 2003. Gesellschaft und Tierproduktion. In: Perspektiven in der Tierproduktion. Landbauforschung Völkenrode Sonderheft 263: 1521

WBA 2015. Wissenschaftlicher Beirat für Agrarpolitik: Wege zu einer gesellschaftlich akzeptierten Nutztierhaltung - Gutachten des Wissenschaftlicher Beirats für Agrarpolitik beim BMEL. Grethe $H$., Christen O., Balmann A., Baushus J., Birner R., Bokelmann W., Gauly M., Knierim U., Latacz-Lohmann U., Nieberg H., Quaim M., Spiller A., Taube F., Weingarten P., Martinez J., Tenhagen B. U. Entenmann S., Berlin: 89-119

Welfare Quality® 2009. Welfare Quality ${ }^{\circledR}$ assessment protocol for pigs (sow and piglets, growing and finishing pigs). Welfare Quality ${ }^{\circledR}$ Consortium, Lelystad, The Netherlands

Wolter B.F., Ellis M., Curtis S.E., Augspurger N.R., Hamilton D.N., Parr E.N. \& Webel D.M. 2001. Effect of group size on pig performance in a wean-tofinish production system. Journal of Animal Science 79: 1067-1073 
KAPITEL 2

Literaturübersicht 


\section{$2 \quad$ Literaturübersicht}

\subsection{Entwicklung der Schweineproduktion in Deutschland}

In Deutschland wurden im Jahr 2014 etwa 28,1 Millionen Schweinen gehalten (Statistisches Bundesamt, 2014). Damit nimmt Deutschland im Rahmen der europäischen und globalen Fleischwirtschaft eine bedeutende Stellung ein. Dies gilt nicht nur für die Produktion, sondern auch für den Handel (Windhorst, 2008). Während der Schweinebestand seit Jahren leicht wächst, sinkt gleichzeitig die Anzahl der schweinehaltenden Betriebe kontinuierlich. Im vergangenen Jahr gaben etwa 2.000 Betriebe (knapp 4\%) ihre Schweinehaltung auf. Damit hat sich die Anzahl der Betriebe auf ca. 27.100 reduziert. Demzufolge ist eine strukturelle Entwicklung zu immer größeren Beständen und einer zunehmenden Anzahl Schweine pro Halter zu beobachten. Im Jahr 2014 stieg die Anzahl gehaltener Schweine pro Landwirt auf durchschnittlich 1.037 an (Abbildung 1).

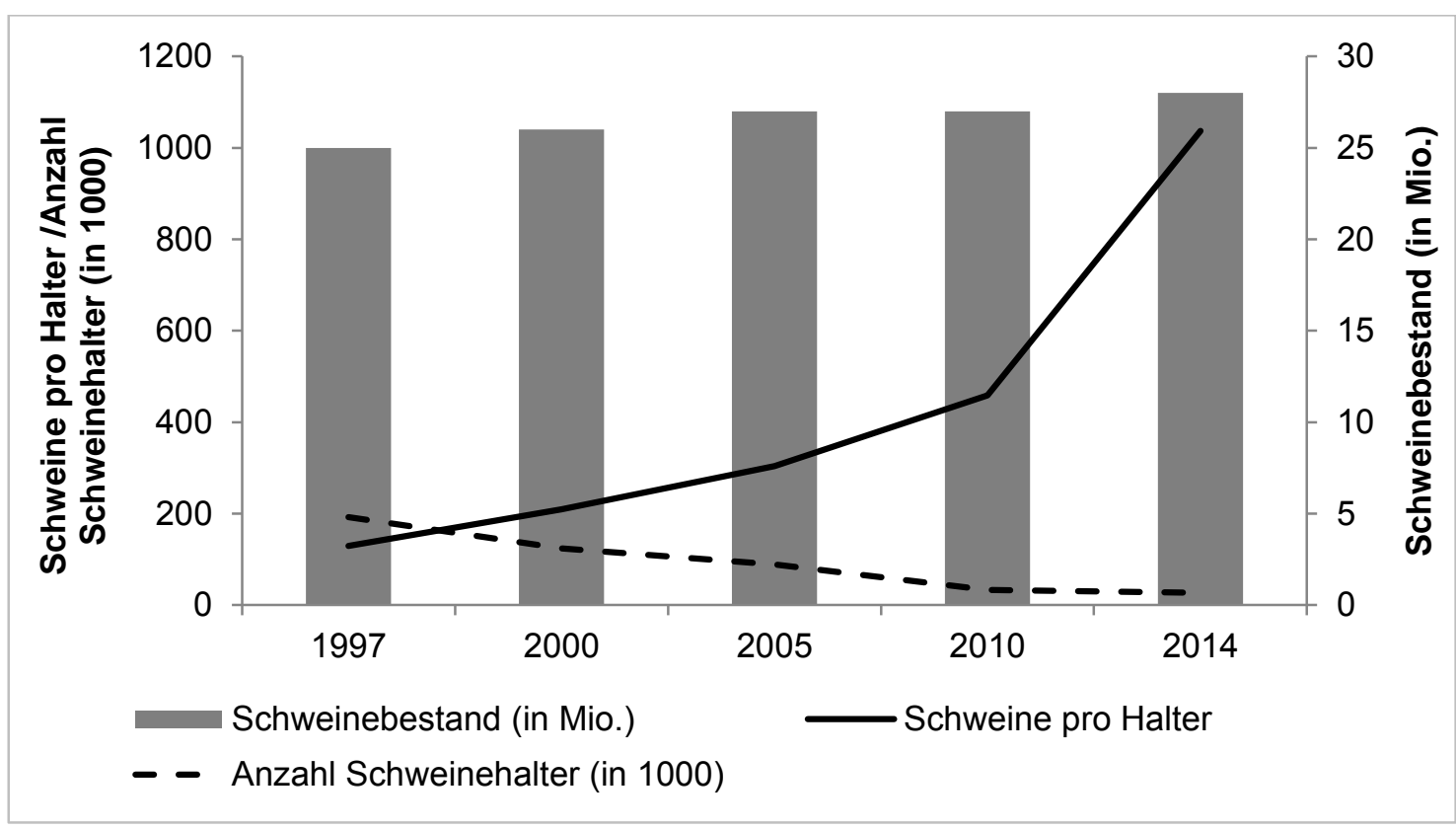

Abbildung 1: Entwicklung der Schweineproduktion in Deutschland (Eigene Darstellung nach Statistisches Bundesamt (2014)) 


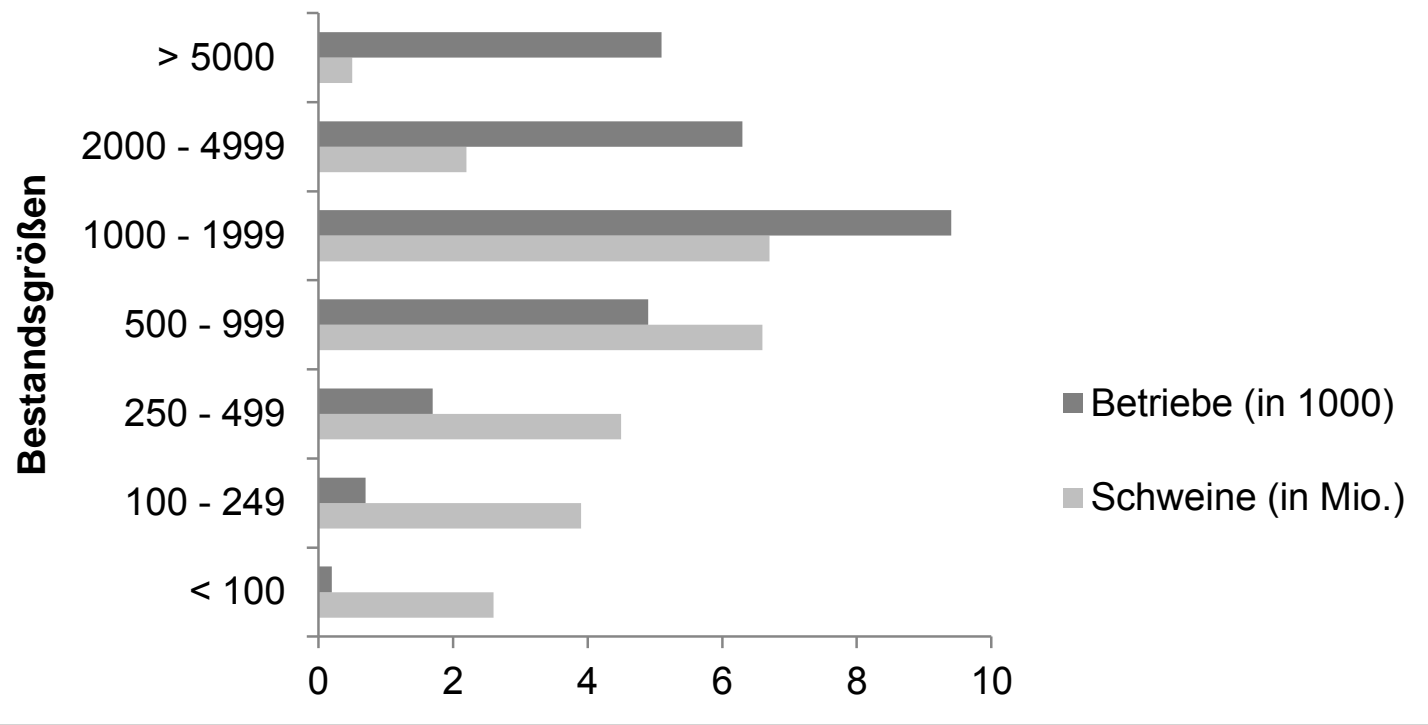

Abbildung 2: Entwicklung der Schweinebestände in Deutschland (Eigene Darstellung nach Statistisches Bundesamt (2014))

In Abbildung 2 sind einerseits die Anzahl Betriebe und andererseits die Anzahl Schweine in Abhängigkeit verschiedener Bestandsgrößenkategorien dargestellt. Etwa $75 \%$ aller in Deutschland gehaltenen Schweine (hellgraue Balken) werden in Betrieben mit 1.000 und mehr Schweinen gehalten. Gleichzeitig haben etwa 50\% der Betriebe Bestände zwischen 500 und 2.000 Mastplätze (dunkelgraue Balken) (Abbildung 2).

Darüber hinaus lässt sich innerhalb Deutschlands eine hohe regionale Konzentration feststellen. In den Bundesländern Nordrhein-Westfalen und Niedersachsen wird über die Hälfte des gesamten deutschen Schweinebestandes gehalten, in den ostdeutschen Bundesländern zusammen nur knapp 15\% (Windhorst \& Bräule, 2011). Bezüglich der Bestandsgrößenstrukturen lässt sich erkennen, dass die Anzahl der in einem Bestand gehaltenen Schweine von Ost nach West und Nord nach Süd deutlich kleiner wird. Die Bestände in den neuen Bundesländern sind teilweise mehr als doppelt so groß (z.B. durchschnittlich 1.581 Schweine pro Betrieb in Sachsen) im Vergleich zu Betrieben in Niedersachsen (durchschnittlich 767 Schweine pro Betrieb) oder Nordrhein-Westfalen (durchschnittlich 648 Schweine pro Betrieb). In Süddeutschland werden deutlich weniger Schweine pro Bestand gehalten: 
2010 betrug die durchschnittliche Bestandsgröße in Bayern 273 Schweine und in Baden-Württemberg 245 Schweine (Windhorst \& Bräule, 2011).

Durch eine deutliche Produktionssteigerung von Schweinefleisch ist der Selbstversorgungsgrad in Deutschland zwischen 2000 und 2014 von 87\% auf 117\% angestiegen (Statista, 2015). Der überschüssig produzierte Anteil wird auf dem Weltmarkt angeboten und verkauft. Unter anderem kann diese Abhängigkeit vom Weltmarkt zu großen Schwankungen des Schweinefleischpreises führen (Windhorst, 2002). Bricht kurzfristig die Nachfrage großer Importeure ein, entsteht ein Überangebot mit der Folge sinkender Preise. Da die meisten Erzeuger aber produktionsbedingt in sehr engen Zeitfenstern große Partien abgeben müssen/wollen, ist der gerade geltende Marktpreis anzunehmen. Um im nationalen und internationalen Markt wettbewerbsfähig zu bleiben, müssen Schweinefleischerzeuger effizient und günstig produzieren (Beckhove, 2008).

Gleichzeitig ist das Interesse der Verbraucher und der Bevölkerung im Allgemeinen an der Erzeugung tierischer Produkte gestiegen (Von Alvensleben, 2003; Vanhonacker et al., 2010). Die Politik versucht zwischen den steigenden Ansprüchen der Gesellschaft (Blokhuis et al., 2003) und den wirtschaftlichen Gegebenheiten der Erzeuger zu vermitteln (WBA, 2015). Die Anforderungen an die Haltung landwirtschaftlicher Nutztiere werden stetig überarbeitet. Für die Schweinehaltung wird u.a. der Verzicht auf das betäubungslose Kastrieren von männlichen Ferkeln und deren Alternativen (Ebermast, Immunokastration) diskutiert. Insbesondere in der Schweinemast hat die Einführung neuer Spaltenweiten (Tierschutz-Nutztierhaltungsverordnung, 2006) sowie die Novellierung des Baugesetzbuches (Baugesetzbuch, 2015) inklusive des Filtererlasses (Bundes-Immissionsschutzgesetz, 2013) in Veredlungsregionen den Strukturwandel verstärkt. Der 2011 erstmals diskutierte Tierschutzplan des Ministeriums für Ernährung, Landwirtschaft und Verbraucherschutz des Landes Niedersachsen befasst sich mit Tierschutzproblemen in der Nutztierhaltung. In Arbeitsgruppen werden Maßnahmen zur Umsetzung der Tierschutzanforderungen in der Praxis erarbeitet. Für die Schweinehalter sind hier weitere Vorgaben im Sinne des Tier- und Umweltschutzes zu erwarten, 
welche auch finanzielle Auswirkungen haben können. Mit einem Effekt auf die künftige Strukturentwicklung in der Schweineproduktion ist zu rechnen (Windhorst, 2002).

\subsection{Problemfelder der konventionellen Schweinemast in Bezug zum Tierwohl}

In Deutschland werden Schweine, die unter konventionellen Haltungsbedingungen gemästet werden, größtenteils in vollklimatisierten und mit automatischen Fütterungssystemen ausgestatteten Ställen gehalten (Hoy et al., 2006). Mehr als 90\% aller Schweine stehen auf perforierten Böden ohne Einstreu (EFSA, 2005). Gruppengrößen variieren zwischen 10 und 30 Tieren pro Bucht, wobei auch Großgruppen (> 50 Tiere/Bucht) (Turner \& Edwards, 2004) und Megagruppen (> 100 Tiere/Bucht) (Samarakone \& Gonyou, 2008) aus Gründen des Managements und aus ökonomischen Gesichtspunkten zunehmend etabliert werden (Schmolke et al., 2003). Abhängig vom Durchschnittsgewicht der Tiere hat jedem Zuchtläufer und Mastschwein eine bestimmte uneingeschränkt nutzbare Mindestbodenfläche zur Verfügung zu stehen. Die entsprechenden gesetzlichen Vorgaben finden sich in der Tierschutz-Nutztierhaltungsverordnung (Tierschutz-Nutztierhaltungsverordnung, 2006). Anforderungen zur Haltung von Schweinen sind detailliert im Abschnitt 5 der Verordnung beschrieben. Als Beschäftigungsmaterial muss gesundheitlich unbedenkliches, bewegliches und veränderbares Material in ausreichender Menge zur Verfügung stehen. Die Tierschutz-Nutztierhaltungsverordnung soll explizit dem „Schutz landwirtschaftlicher Nutztiere und anderer zur Erzeugung tierischer Produkte gehaltener Tiere bei ihrer Haltung" dienen. Dennoch treten in der Schweinemast u.a. folgende tierschutzrelevante Probleme auf (WBA, 2015):

- Haut-, Gelenk-, und Klauenverletzungen (Turner et al., 2006; Gillman et al., 2008; Busch \& Wachmann, 2011)

- Lahmheiten und Fundamentprobleme (Mouttotou et al., 1998; Busch \& Wachmann, 2011) 
- Schwanzbeißen und Kannibalismus (Schrøder-Petersen \& Simonsen, 2001; Moinard et al., 2003; EFSA, 2007b; Taylor et al., 2012; Thays Sonoda et al., 2013; D'Eath et al., 2014)

- Infektionserkrankungen (Mousing et al., 1997; Lo Fo Wong et al., 2004; Zheng et al., 2007; Maes et al., 2008; Baptista et al., 2010; Nathues et al., 2012; Grøntvedt et al., 2013).

- Vermehrt Auseinandersetzungen unter den Schweinen (McGlone \& Newby, 1994; Velarde \& Geers, 2007)

- Stressbedingte Todesfalle von Mastschweinen (Lebret et al., 2015)

- Schmerzen durch Eingriffe wie Kastration und Schwanzkürzen (EFSA, 2007b; Sutherland et al., 2008)

- Verhaltenseinschränkung, Verhaltensstörungen und Stereotypien (Van de Weerd \& Day, 2009; Tönepöhl et al., 2012)

Wichtige Einflussfaktoren auf deren Auftreten sind (WBA, 2015):

- Liegeplatz- und Bodenbeschaffenheit

- Platzangebot, Gruppengrößen

- Fütterungssysteme und Qualität des Futters

- Beschäftigungs- und Abkühlungsmöglichkeiten

- Wahlmöglichkeit zwischen verschiedenen Funktions- und Klimabereichen

- Stallklima (Luftqualität, Temperatur)

- Quantität und Qualität der Wasserversorgung

- Sachkunde der betreuenden Personen und damit Qualität des Managements

- Einhaltung und Umsetzung vorhandener Vorschriften

Die aufgeführten Erkrankungen bzw. Verhaltensstörungen sind größtenteils multifaktoriell bedingt (EFSA, 2005; 2007a). Eine Verbesserung der Tiersituation ist nur durch umfassende Maßnahmen auf der Ebene der Haltung, des (Gesundheits-) Managements und der Zucht sowie unter Einbeziehung aller Produktionsstufen zu erreichen (WBA, 2015). Darüber hinaus haben die 
Kenntnisse und Fähigkeiten der betreuenden Personen einen erheblichen Einfluss (Waiblinger et al., 2006).

Des Weiteren werden insbesondere die nicht-kurativen Eingriffe am Tier zunehmend kontrovers diskutiert. Nicht-kurative Eingriffe sind operative und in der Regel schmerzhafte Amputationen von Körperteilen, die das Management erleichtern sowie die Fleischqualität sichern sollen (EFSA, 2007b). Nach dem Tierschutzgesetz sind routinemäßige Amputationen und das Vornehmen eines mit Schmerzen verbundenen Eingriffes grundsätzlich verboten (Tierschutzgesetz, 2006). Für das Kastrieren von bis zu acht Tage alten Ferkeln, das Kürzen von Schwanzspitzen bei bis zu vier Tage alten Ferkeln und dem Abschleifen von Eckzähnen wurden Ausnahmetatbestände geschaffen. Die beiden erstgenannten Eingriffe werden routinemäßig durchgeführt: Nach einem Bericht der EFSA (2007b) werden bei 90 - 95\% aller Mastschweine die Schwänze kupiert.

\section{$2.3 \quad$ Tierwohl}

\subsubsection{Gebräuchliche Begriffe und deren Definitionen}

Der Begriff „Tierwohl“ wird erst in jüngster Zeit zunehmend verwendet. Er ist vergleichbar mit den Bezeichnungen „Wohlergehen“ und "Wohlbefinden“ (Broom \& Fraser, 2007). Knierim (2010), zitiert nach dem Gutachten des wissenschaftlichen Beirates (WBA, 2015), fasst unter dem Begriff „Tierwohl“ die vier Zielgrößen des Tierschutzgesetzes d.h. die Abwesenheit von Schmerzen, Leiden und Schäden sowie die Sicherung von Wohlbefinden zusammen. Das Tier mit all seinen körperlichen und psychischen Ansprüchen steht im Vordergrund. Die Bezeichnung "Tierwohl“ löst in Teilen den ursprünglich gebräuchlichen Begriff der "Tiergerechtheit“ ab (Ingenbleek et al., 2012). Nach Duncan \& Fraser (1997) umfasst der Begriff der "Tiergerechtheit“ die Aspekte Tiergesundheit, die Ausführbarkeit von natürlichen Verhaltensweisen und das Wohlbefinden eines Tieres. Für Sundrum (1998) stehen bei Beurteilung der "Tiergerechtheit" die Umweltbedingungen im Vordergrund. Es wird bewertet, ob das Tier in der Lage ist, unter den vorhandenen Haltungsbedingungen 
Schmerzen, Leiden und Schäden zu vermeiden sowie ein gutes Wohlbefinden (psychischer Zustand) zu erreichen. Der Begriff „Tierschutz“ beschreibt, was veranlasst werden muss, damit ein hohes Tierwohl bzw. eine hohe Tiergerechtheit erreicht werden kann. Im englischen Sprachgebrauch wird üblicherweise der Begriff „animal welfare“ zur Beschreibung des physischen und psychischen Zustands von Tieren verwendet. Er schließt sowohl die Abwesenheit von körperlichen und seelischen Leiden als auch das Erleben positiver Erfahrungen ein (Scott et al., 2001; Broom \& Fraser, 2007; Miele et al., 2011).

Die genannten Begriffe lassen gewisse Interpretationsspielräume zu und können oft nicht ohne Bedeutungsverlust in den jeweiligen Sprachgebrauch übersetzt werden. So wird der Begriff "Wohlbefinden“ eher mit "well-being“ übersetzt und nicht mit „animal welfare“. „Animal welfare“ wird durchaus mit Tierwohl übersetzt, das fast gleichbedeutend zu dem Begriff „Wohlbefinden“ verwendet wird (Knierim, 1998; 2002).

Es lässt sich zusammenfassen, dass die Begriffe Tierschutz, Tierwohl, Wohlergehen und Tiergerechtheit letztlich alle auf die möglichst weitgehende Abwesenheit von Schmerzen, Leiden und Schaden sowie die Sicherung von Wohlbefinden beim Tier abzielen (WBA, 2015).

\subsubsection{Methoden zur Tierwohlbewertung - das Welfare Quality® Protokoll für Mastschweine}

In den 1980er Jahren wurde vom britischen Farm Animal Welfare Council (FAWC) das Konzept der „5 Freiheiten“ entwickelt (FAWC, 1992). Es stellt die Basis für einen Großteil der Methoden zur Bewertung des Tierwohls in der Nutztierhaltung dar. Zu den 5 Freiheiten gehören:

- Freiheit von Hunger und Durst

- Freiheit von haltungsbedingten Beschwerden

- Freiheit von Schmerz, Verletzungen und Krankheiten

- Freiheit von Angst und Stress

- Freiheit zum Ausleben normaler Verhaltensmuster 
Die Bestimmung des Ist-Zustandes (Problemfelder) auf den Betrieben ist Voraussetzung zur Verbesserung des Tierwohls. Hierfür ist eine valide, praktikable und zuverlässige Methode erforderlich, die Tierwohl mit Hilfe messbarer Indikatoren erfassbar macht. Nur so ist eine Bewertung der Resultate hinsichtlich ihrer Bedeutung für das Tier möglich (Knierim, 1998). In der nachfolgenden Tabelle wird eine Auswahl verschiedener Beurteilungssystem dargestellt.

Tabelle 1: Einteilung verschiedener Methoden zur Erfassung des Tierwohls (eigene Darstellung)

\begin{tabular}{l|l|l|l}
\hline & $\begin{array}{l}\text { Umweltbezogene } \\
\text { Methoden }\end{array}$ & $\begin{array}{l}\text { Tierbezogene } \\
\text { Methoden }\end{array}$ & $\begin{array}{l}\text { Integrative } \\
\text { Methoden }\end{array}$ \\
\hline Schwerpunkt & $\begin{array}{l}\text { Management und } \\
\text { Haltung }\end{array}$ & $\begin{array}{l}\text { Gesundheit und } \\
\text { Verhalten }\end{array}$ & $\begin{array}{l}\text { Management, } \\
\text { Haltung, } \\
\text { Gesundheit und } \\
\text { Verhalten }\end{array}$ \\
Beispiele & $\begin{array}{l}\text { Platzangebot, Boden, } \\
\text { Stallklima, Fütterung } \\
\text { usw. }\end{array}$ & $\begin{array}{l}\text { Verwundungsgrad, } \\
\text { Schwanzbeißen, } \\
\text { Stereotypen usw. }\end{array}$ & $\begin{array}{l}\text { Fütterungs- und } \\
\text { Lüftungstechnik, } \\
\text { Verhaltensstörung, }\end{array}$ \\
Nachteile & $\begin{array}{l}\text { Gute Praktikabilität } \\
\text { und Wiederholbarkeit, } \\
\text { Mittlere Validität }\end{array}$ & $\begin{array}{l}\text { Mittlere Praktikabilität } \\
\text { und Wiederholbarkeit, } \\
\text { Gute Validität }\end{array}$ & $\begin{array}{l}\text { Mittlere bis gute } \\
\text { Praktikabilität, } \\
\text { Wiederholbarkeit } \\
\text { und Validität }\end{array}$ \\
Methoden & $\begin{array}{l}\text { Tiergerechtheits- } \\
\text { index 35 } \\
\text { Tiergerechtheits- } \\
\text { index 200 } \\
\text { Kritische } \\
\text { Kontrollpunkte }\end{array}$ & $\begin{array}{l}\text { Bedarfsdeckung- } \\
\text { und } \\
\text { Schadensvermei- } \\
\text { dung }\end{array}$ & $\begin{array}{l}\text { DLG-Prüfung } \\
\text { WQßP }\end{array}$ \\
\hline
\end{tabular}


Ursprünglich wurde für die Beurteilung des Tierwohls ausschließlich die Haltungsumwelt wie Flächenangebot, Bodengestaltung oder auch Wasserverfügbarkeit herangezogen (umweltbezogene Methoden vgl. Tabelle 1). Sogenannte ressourcen- und managementbezogene Indikatoren lassen sich vergleichsweise leicht und unabhängig von den Fähigkeiten des Beobachters erfassen. Darüber hinaus weisen sie eine hohe Übereinstimmung zwischen verschiedenen Personen und zwischen verschiedenen Beurteilungen auf (Johnsen et al., 2001). Viele dieser anfänglichen Ansätze (Checklisten, Ampelsysteme) zur Beurteilung der Tiergerechtheit waren allerdings nur auf einzelne Aspekte beschränkt. Ein System, das auf Checklisten basierte, wurde von Bartussek (1996) vorgestellt. Es handelte sich um die erste Version des Tiergerechtheitsindexes (Tiergerechtheitsindex 35), der mehrfach weiterentwickelt wurde (Tiergerechtheitsindex 200) und heute noch Anwendung bei der Bewertung von Haltungsverfahren findet. Die Bereiche Bewegungsmöglichkeit, Sozialkontakt, Bodenbeschaffenheit, Licht, Luft und Lärm sowie die Betreuungsintensität wurden mit Punkten bewertet. Ein weiteres umweltbezogenes Konzept zur Tierwohlbewertung sind die kritischen Kontrollpunkte nach Sanftleben et al. (2007). Dabei wird dem Management neben den baulich-technischen Voraussetzungen eine sehr hohe Bedeutung zugeschrieben. Kontrollpunkte wurden u.a. definiert für den Bereich der Fütterung und Tränkwasserbereitstellung sowie für die Tier- und Gesundheitskontrolle. Die grundsätzliche Kritik an diesen Bewertungssystemen ist, dass sie zu wenig auf die direkten Tierindikatoren eingehen. In diesen Systemen wird davon ausgegangen, dass sich die Tiere wohl fühlen, wenn die Haltungsumwelt ihren Ansprüchen genügt. Dieser Zusammenhang ist in vielen Fällen wissenschaftlich nur grob oder gar nicht belegt (Knierim, 1998).

Nach Knierim (2002) und Sundrum (1998) sind eine Vielzahl von Faktoren für die umfassende Beurteilung des Tierwohls notwendig, wobei v.a. auch direkte tierbezogene Indikatoren herangezogen werden sollten. Sie weisen einen höheren Erklärungswert für das Wohlergehen der Tiere auf und führen damit zu gültigeren Aussagen bezüglich des Tierwohls (Blokhuis et al., 2003). Einer der ersten Ansätze zur Beurteilung der Tiergerechtheit, der sich an direkten 
tierbezogenen Indikatoren orientierte, war das Bedarfsdeckungs- und Schadensvermeidungskonzept von Tschanz (1985). In diesem Ansatz wird davon ausgegangen, dass Lebewesen zum Selbstaufbau, zur Selbsterhaltung und zur Fortpflanzung fähig sind. Allerdings müssen hierfür bestimmte Stoffe und Reize vorhanden sein. Tschanz (1985) geht davon aus, dass nur der Schaden am Lebewesen direkt zu erfassen ist, während Bedarf, Bedarfsdeckung und Schadensvermeidung nicht direkt $\mathrm{zu}$ ermitteln sind. Jedoch sind derartige direkte tierbezogene Indikatoren zur Beurteilung der Gesundheit und des Verhaltens aufwendiger zu messen, da die erhebende Person gewisse Kenntnisse und Fähigkeiten mitbringen muss. Darüber hinaus ist die Beurteilung zeitintensiver und bringt erhebliche Herausforderungen bezüglich der Praktikabilität, der standardisierten Erfassung und der Verallgemeinbarkeit von einzelnen Beurteilungen mit sich (Knierim \& Winckler, 2009; WBA, 2015).

Die Praktikabilität eines Beurteilungssystems ist die Grundvoraussetzung für eine Anerkennung in der Praxis. Die Indikatoren müssen routinemäßig auf den Betrieben erhoben werden können und die Durchführbarkeit muss auch bei großen Tierzahlen möglich sein. Voraussetzung für eine standardisierte Erfassung mit einer hohen Wiederholbarkeit ist die klare Definition der Indikatoren. So muss z.B. bei dem Indikator Verschmutzungsgrad jedem Prüfer eine klare Beschreibung der Scores (keine Verschmutzung, mittlere Verschmutzung, starke Verschmutzung) vorliegen. Allerdings kann keine der beschriebenen Indikatorengruppen für sich genommen das Tierwohl in seiner Gesamtheit erfassen (Botreau et al., 2007a; Botreau et al., 2007b).

Um eine umfassende Betrachtung des Tierwohls zu erhalten, müssen die verschiedenen Indikatorengruppen kombiniert werden. Dies bedeutet, dass sowohl das Haltungssystem bzw. die Haltungsumwelt als auch das Management und das Tier selbst in die Bewertung einbezogen werden müssen (Johnsen et al., 2001; Knierim, 2002). Solch eine integrative Methode ist z.B. das DLG-Prüfverfahren (Von Borell et al., 2012). Ein vergleichsweise neues und international weitestgehend anerkanntes Konzept zur Beurteilung des Tierwohls auf Betriebsebene ist das Welfare Quality ${ }^{\circledR}$ Protokoll (Welfare Quality ${ }^{\circledR}, 2009$ ). 
Das Welfare Quality® Protokoll soll praktikable Indikatoren für die drei Bereiche Haltung, Management und das Tier selbst beinhalten, die den bisherigen gesellschaftlichen und wissenschaftlichen Anforderungen entsprechen (Blokhuis, 2008). Im folgenden Abschnitt wird der Aufbau des Welfare Quality® Assessment Protokolls für Schweine dargestellt. Es ist die dieser Arbeit zugrundeliegende Methode zur Bewertung des Tierwohls auf den Betrieben.

\section{Das Welfare Quality® Assessment Protokoll für Mastschweine}

Das Welfare Quality ${ }^{\circledR}$ Assessment Protokoll (WQP) entstand aus der Zusammenarbeit von 40 Instituten und Universitäten aus 13 EU-Ländern im Jahr 2004. Später folgten vier Lateinamerikanische Länder, die sich an der Weiterentwicklung des Protokolls beteiligten. Das WQP findet gegenwärtig in der Wissenschaft die größte Beachtung. Es ist ein vornehmlich tierorientiertes Indikatorensystem, dass der umfassenden Beurteilung des Tierwohls von Nutztieren auf Betriebsebene dient. Hauptaugenmerk liegt auf den Bedürfnissen der Tiere und der Art, wie sie mit ihrer Umwelt agieren. Haltungsbedingungen und Managementangelegenheiten werden mit in die Beurteilung einbezogen, jedoch weniger gewichtet. Entsprechend werden vergleichsweise wenige Kennziffern bezüglich des Managements (Kastration, Kupieren der Schwänze) und der Haltung (Wasserversorgung, Platzangebot) erhoben. Bedeutsamer sind direkte (z.B. Bursitis, Verschmutzungsgrad etc.) und indirekte tierbezogene Indikatoren (z.B. Mortalität), die bei einer umfassenden Tierbeobachtung ermittelt werden. Das WQP beinhaltet vier verschiedene Stufen. Aus den Indikatoren (Measures) werden in einem Aggregierungsprozess 12 Kriterien (Criteria), 4 Grundsätze (Principles) und schließlich ein einziger Gesamtscore (Overall assessment) gebildet (Abbildung 3) (Welfare Quality $\AA$, 2009). 


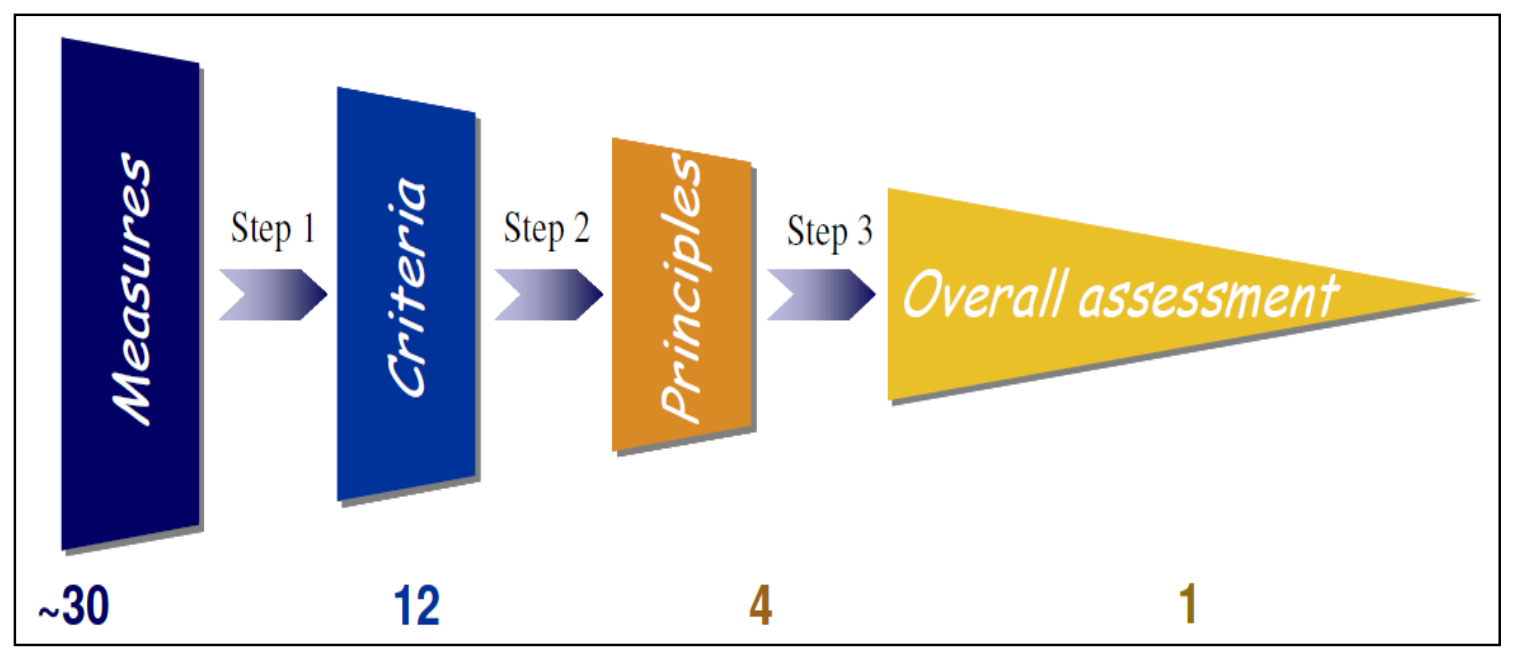

Abbildung 3: Der Aggregierungsprozess von der Ebene der Indikatoren zum Gesamtscore (Welfare Quality®, 2009)

Die einzelnen Grundsätze, Kriterien und Indikatoren sind in Tabelle 2 in einer Übersicht dargestellt und geben den Aufbau des Welfare Quality® Protokolls wieder. Die erhobenen Indikatoren wurden hinsichtlich ihrer Bedeutung für das Wohlergehen der Schweine gewichtet: Je nach Stärke ihres Einflusses wirken sich die erhobenen Resultate auf die nachfolgende Stufe des Protokolls aus und beeinflussen die Punktevergabe innerhalb der zwölf Kriterien. Die Überführung der Daten in das von dem WQP vorgesehene Punkteschema (0 100 Punkten) erfolgt dabei über verschiedene mathematische Verfahren. Einige Kriterien werden über Entscheidungsbäume gebildet (z.B. Wasserverfügbarkeit, Kastration). Andere Indikatoren (z.B. Körperkondition) werden gewichtet oder zunächst innerhalb festgelegter Warn - oder Alarmschwellen eingeordnet (z.B. Schlachtbefunde, Husten und Niesen) und anschließend in einer sogenannten I-Spline-Funktion in das entsprechende Punkteschema transformiert.

Die einzelnen Kriterien werden im Verlauf des Protokolls zu den vier Grundsätzen Fütterung, Haltung, Gesundheit und Verhalten zusammengefasst und müssen hinsichtlich ihrer Bedeutung für das Tierwohl gewichtet werden. Dies geschieht über die Verwendung von Choquet-Integralen. Dazu werden die in dem jeweiligen Grundsatz enthaltenen Kriterien zunächst aufsteigend nach ihrer erreichten Punktzahl sortiert. Danach erfolgt die Berechnung des entsprechenden Grundsatzes. Die erzielten Punkte der vier Grundsätze werden 
abschließend in einem Gesamturteil kombiniert. Dieses besteht jedoch nicht aus einer Gesamtpunktzahl oder einem Durchschnittsscore aller vier Grundsätze, sondern wird lediglich im Rahmen einer Klassifizierung des Betriebes hinsichtlich des Tierwohls dargestellt, um eine mögliche Kompensation zwischen den Grundsätzen zu verhindern. Die Betriebe müssen verschiedene Schwellenwerte überschreiten, um als "ausgezeichnet", „verbessert" oder „akzeptabel“ bewertet zu werden. Erfüllt ein Betrieb diese Anforderungen nicht, wird er als "nicht klassifiziert" eingestuft. Um für den Gesamtbetrieb ein „ausgezeichnet“ zu bekommen, müssen in allen vier Grundsätzen mindestens 55 Punkte erreicht werden und in zwei der vier Grundsätze zusätzlich mehr als 80 Punkte. Ein Gesamturteil „verbessert" wird erzielt, wenn in allen Grundsätzen mindestens 20 Punkte und in zwei Grundsätzen 55 Punkte erreicht werden. Ein „akzeptabel“ wird erreicht, wenn bei drei Grundsätzen mehr als 20 Punkte erzielt werden und der vierte Grundsatz nicht weniger als 10 Punkte erreichte. 
Tabelle 2: Aufbau des Welfare Quality $®$ Protokolls für Mastschweine (verändert nach Temple et al. (2011))

\begin{tabular}{|c|c|c|c|}
\hline Bewertung & Grundsätze & Kriterien & Indikatoren \\
\hline \multirow[t]{24}{*}{ Gesamtscore } & Fütterung & 01 Hunger & Körperkondition \\
\hline & & 02 Durst & Wasserangebot \\
\hline & Haltung & 03 Liegekomfort & Bursitis, \\
\hline & & & Verschmutzungsgrad \\
\hline & & 04 Klimakomfort & Zittern, Hecheln, \\
\hline & & & Haufenlage \\
\hline & & 05 Bewegungsfreiheit & Platzangebot \\
\hline & Gesundheit & 06 Verletzungen & Lahmheit, Wunden, \\
\hline & & & Schwanzbeißen \\
\hline & & 07 Krankheiten & Mortalität, Husten, \\
\hline & & & Niesen, Schwere \\
\hline & & & Atmung, verdrehte \\
\hline & & & Schnauze, rektaler \\
\hline & & & Prolaps, \\
\hline & & & Hautkondition, \\
\hline & & & Brüche, Hernien, \\
\hline & & & Schlachtbefunde \\
\hline & & 08 Schmerzen & Kastration, \\
\hline & & & Schwanzkupieren \\
\hline & Verhalten & 09 Sozialverhalten & Sozialverhalten \\
\hline & & 10 Sonstiges Verhalten & Erkundungsverhalten \\
\hline & & 11 Mensch-Tier-Beziehung & Angst vor Menschen \\
\hline & & 12 Emotionaler Zustand & Qualitative \\
\hline & & & Verhaltensbeurteilung \\
\hline
\end{tabular}

\subsubsection{Zusammenhang zwischen Bestandsgröße und Tierwohl}

Im Rahmen des Gutachtens des wissenschaftlichen Beirates wurden untersuchungsleitende Thesen formuliert, die die Beziehung zwischen der Größe eines tierhaltenden Betriebes und dem Tierschutz beschreiben. Die 
verschiedenen Thesen werden in Abbildung 4 graphisch dargestellt (WBA, 2015):

- Professionalisierungsthese: Mit dem Wachstum und der Spezialisierung der Betriebe sind meistens ökonomische Vorteile verbunden, die größer sind als mögliche größenbedingte Nachteile für das Tierwohl. Demnach sind größere Betriebe auch im Tierschutz führend. Dagegen spricht, dass größere Betriebe zwar oft professioneller wirtschaften, aber aus Kostengründen vielfach angelernte Arbeitskräfte anstelle von Fachkräften beschäftigen, wodurch Defizite in der Tierbetreuung entstehen können. Das Ziel einer strikten Kostensenkung kann dazu führen, dass Aufwendungen für mehr Tierwohl unterlassen werden.

- Small is beautiful - These: Kleinere Familienbetriebe mit mehreren Betriebszweigen, ohne Fremdarbeitskräfte und mit der Motivation und Kompetenz des Betriebsleiters können Vorteile haben. Allerdings können gerade die wenig spezialisierten Betriebe Kompetenzdefizite in bestimmten Bereichen aufweisen und haben oft wenig ökonomischen Spielraum, was sich negativ auf bestimmte tierwohlsteigende Maßnahmen auswirken kann.

- U-Kurven - Hypothese: Kleinere Betriebe können Vorteile im Tierwohl aufweisen (s. Small is beautiful - These: intensivere Tierbetreuung), die mit steigender Betriebsgröße verloren gehen. Ab einer gewissen Betriebsgröße steigt das Tierwohl jedoch möglicherweise wieder an, da eine zunehmende Professionalisierung stattfindet (s. Professionalisierungsthese).

- Umgekehrte U-Kurven - Hypothese: Während kleinere Betriebe aufgrund der starken multifaktoriellen Ausrichtung und möglicher damit einhergehender Wissensdefizite im Speziellen Nachteile aufweisen können, haben große Betriebe häufig nicht entsprechend ausgebildetes bzw. motiviertes Personal, sodass mittlere Betriebsgrößen Vorteile im Hinblick auf das Tierwohl haben können. 
- Indifferenzthese: Es gibt keinen Zusammenhang zwischen der Größe eines tierhaltenden Betriebes und dem Tierwohl. Vielmehr wird das Tierwohl durch Managementmaßnahmen und das Haltungssystem beeinflusst.

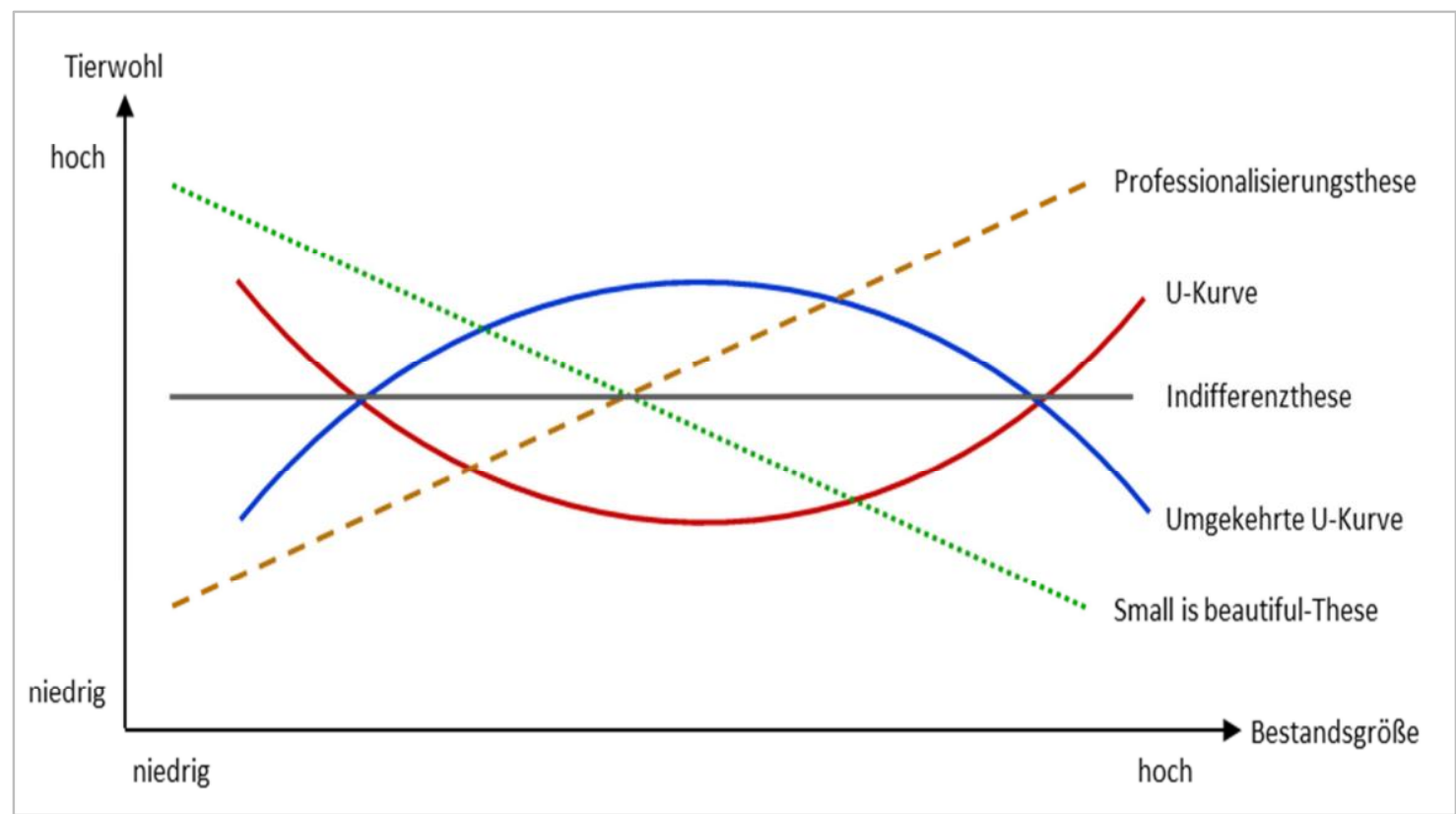

Abbildung 4: Theorien zum Zusammenhang Bestandsgröße und Tierwohl (WBA, 2015)

Bereits auf theoretischer Ebene wird die Komplexität des Zusammenhangs zwischen Bestandsgröße und Tierwohl deutlich. Darüber hinaus sind wissenschaftliche Untersuchungen zu möglichen Zusammenhängen zwischen Tierwohl und Bestandsgröße kaum vorhanden. Die wenigen Studien betrachten nur einzelne Teilaspekte des Tierwohls und lassen keine präzise Aussage bezüglich des Zusammenhangs zwischen Bestandsgröße und Tierwohl zu. Bemerkenswert ist, dass z.B. auch der Zusammenhang zwischen Bestandsgröße und dem Vorkommen von Erkrankungen nicht eindeutig hergestellt werden kann, obwohl es auf theoretischer Ebene durchaus Argumente für einen positiven Zusammenhang zwischen der Bestandsgröße und dem Auftreten von Krankheiten gibt. Hierbei werden folgende Risiken für größere Betriebe diskutiert: 
- Das Risiko der Eintragung von Pathogenen von außen in die Herde ist größer (durch vermehrten Zukauf) (Gardner et al., 2002)

- Das Risiko der Übertragung von Pathogenen innerhalb und zwischen Herden auf Grund einer höheren Anzahl potentiell empfänglicher Tiere ist größer (Gardner et al., 2002)

- Es gibt eine Kumulation von verschieden Risikofaktoren (Broens et al., 2011)

- Es besteht evtl. eine höhere Stressanfälligkeit beim Tier, die zu einer Schwächung des Immunsystems führen und die Schweine damit empfänglicher für Infektionskrankheiten machen kann (Maes et al., 2008)

Andererseits sind Hygienevorrichtungen, die das Risiko einer Infektion und deren Verbreitung herabsetzen, in großen Betrieben häufiger vorhanden. Zudem sind die Einhaltung der Hygienepraxis sowie andere Managementmaßnahmen besser durchzuführen als in kleineren Betrieben (Gardner et al., 2002). Demnach kann angenommen werden, dass durch ein vermeintlich besseres Management in größeren Betrieben das zunächst höher angenommene Infektionsrisiko sowie die Verbreitung von Erregern reduziert werden kann.

Belastbare Studien, die einen möglichen Zusammenhang zwischen der Bestandsgröße und der Prävalenz von Krankheiten untersucht haben, sind nur für wenige Schweinekrankheiten bekannt. Bezüglich des Einflusses der Bestandgröße auf das Vorkommen von Salmonellose sind die Studienergebnisse nicht eindeutig. So fanden Carstensen \& Christensen (1998) in ihren Untersuchungen ein erhöhtes Vorkommen bei steigender Bestandgröße. Van der Wolf (2001) stellte dagegen ein geringeres Risiko für eine Salmonellose mit zunehmender Bestandsgröße fest. Andere Autoren (Mousing et al., 1997; Lo Fo Wong et al., 2004; Zheng et al., 2007; Baptista et al., 2010) fanden keine Zusammenhänge. Bei den Atemwegserkrankungen „Enzootische Pneumonie“ sowie „Influenza“ konnte ebenfalls kein direkter Effekt der Bestandsgröße beobachtet werden (Maes et al., 2008; Nathues et al., 2012; Grøntvedt et al., 2013). 
Bezüglich des Einflusses der Bestandgröße auf das Tierwohl gibt es ebenfalls nur wenige Studien, die auch nur Teilaspekte betrachten. So konnte Lawrence (2013) keinen Zusammenhang zwischen der Bestandsgröße und dem Ausüben von Normalverhalten beobachten. Knage-Rasmussen et al. (2013) stellten keinen Zusammenhang zwischen der Anzahl Mastschweine pro Betrieb (120 bis 7.825 Schweine/Betrieb) und einem Welfare Index bestehend aus Verhaltens- und Gesundheitsindikatoren fest. Das Vorkommen von Schwanzbeißen, eines der bedeutendsten Tierschutzprobleme in der Schweinhaltung (Thays Sonoda et al., 2013), wird ebenfalls nicht von der Bestandsgröße beeinflusst (Moinard et al., 2003). In Tabelle 3 werden die zugrunde gelegten Bezugsgrößen (Anzahl Herden bzw. Anzahl Sauen oder Mastschweine) sowie die jeweiligen Länder, in der die Studien durchgeführt wurden, aufgeführt. Bei allen dargestellten Studien ist zu beachten, dass die Datenerhebung, die Einteilung in die Bestandsgrößen-Kategorien, das Leistungsniveau der Schweine, das Haltungssystem und die Genetiken sehr unterschiedlich sein können. Somit sind die Ergebnisse nur bedingt vergleichbar. Insgesamt sind sowohl positive, negative als auch gar keine Effekte festzustellen. 
Tabelle 3: Zusammenhang zwischen dem Vorkommen von Salmonellosen, Pneumonie, Influenza sowie der Prävalenz bestimmter Verhaltensweisen und der Bestandsgröße (eigene Darstellung)

\begin{tabular}{|c|c|c|c|}
\hline Studie & Land & $\begin{array}{l}\text { Bezugsgröße: } \\
\text { Herden(n) oder } \\
\text { MS(n)/Herde }\end{array}$ & $\begin{array}{l}\text { Einfluss } \\
\text { Bestands- } \\
\text { größe } \\
(+/-/ 0)\end{array}$ \\
\hline
\end{tabular}

\section{Salmonellose}

\begin{tabular}{|c|c|c|c|}
\hline Mousing et al. (1997) & DK & 100 bis $>5.000 \mathrm{MS} / \mathrm{Herde}$ & $\begin{array}{l}<3.000 \mathrm{MS}+ \\
>3.000 \mathrm{MS}-\end{array}$ \\
\hline Zheng et al. (2007) & DK & 300 bis $5.000 \mathrm{MS} / \mathrm{Herde}$ & $\begin{array}{l}<1.000 \mathrm{MS}+ \\
>1.000 \mathrm{MS}-\end{array}$ \\
\hline Van der Wolf (2001) & $\mathrm{NL}$ & 353 Herden & - \\
\hline $\begin{array}{l}\text { Carstensen \& } \\
\text { Christensen (1998) }\end{array}$ & DK & 14.593 Herden & + \\
\hline $\begin{array}{l}\text { Lo Fo Wong et al. } \\
\text { (2004) }\end{array}$ & $\begin{array}{l}\mathrm{D}, \mathrm{DK}, \\
\mathrm{G}, \mathrm{NL}, \\
\mathrm{S}\end{array}$ & 359 Herden & 0 \\
\hline Baptista et al. (2010) & $\mathrm{P}$ & 108 Herden & 0 \\
\hline
\end{tabular}

\section{Pneumonie}

(Grosse Beilage et al., 2009)

Nathues et al. (2012)

Maes et al. (2000)

Enoe et al. (2002)
D

67 Sauenherden

D

B

DK

\section{Influenza}

$\mathrm{N}$
118 Sauenherden
100 bis 900 Sauen/Herde

112 Sauenherden

0

114 bis 2700 Sauen/Herde

0

50 bis $>200$ Sauen/Herde $\quad 0$

500 bis $>2.000 \mathrm{MS} /$ Herde - 
Maes et al. (2000)

B

50 bis 250 Sauen/Herde

0

Normalverhalten/

Welfare Index

Lawrence, 2013

UK

0

Knage-Rasmussen et

DK

37 Herden

0

al. (2013)

120 bis $7.825 \mathrm{MS} / \mathrm{Herde}$

\section{Schwanzbeißen}

Moinard et al. (2003)

UK

92 Herden

MS = Mastschweine; $\mathrm{n}=$ Anzahl Tiere bzw. Herden; Salmonellosen, Pneumonie, Influenza sowie die Prävalenz bestimmter Verhaltensweisen nimmt zu (+), bleibt unbeeinflusst (0) oder nimmt ab (-) mit steigender Bestandsgröße; DK = Dänemark, NL $=$ Niederlande, $\mathrm{D}=$ Deutschland, $\mathrm{G}=$ Griechenland, $\mathrm{S}=$ Schweden, $\mathrm{P}=$ Portugal, $\mathrm{B}=$ Belgien, $\mathrm{N}=$ Norwegen

\subsubsection{Zusammenhang zwischen Gruppengröße und Tierwohl}

Schweine sind von Natur aus keine Einzelgänger, sondern sie leben in Sozialverbänden (Gonyou, 2001). Demnach ist die Gruppenhaltung der Einzelhaltung bei artgerechter Haltung der Tiere vorzuziehen. Sie ist gekennzeichnet durch mehr Bewegungsfreiheit und einer Vielzahl an Sozialkontakten. Gängige Gruppengrößen variieren zwischen 10 und 30 Tieren pro Bucht. Allerdings etablieren Landwirte aus ökonomischen Gründen größere Gruppengrößen. Durch ein optimiertes Management kann die eingesetzte Arbeitskraft effizienter genutzt werden (Schmolke et al., 2003). Entsprechend wurde die Kleingruppe mit 12 bis 15 Schweinen pro Bucht teilweise durch Großgruppen (> 50 Tiere/Bucht) (Turner \& Edwards, 2004) und sogar Megagruppen (> 100 Tiere/Bucht) (Samarakone \& Gonyou, 2008) verdrängt.

Die steigenden Gruppengrößen in der Tierhaltung stehen allerdings zunehmend in der gesellschaftlichen Kritik (Schröder \& McEachern, 2004; Vanhonacker et al., 2009; Velarde et al., 2015). Umfassende Studien bezüglich des Zusammenhangs zwischen Tierwohl und Gruppengrößen in der Schweinemast wurde bisher jedoch kaum angegangen. Untersuchungen $\mathrm{zu}$ den 
Zusammenhängen zwischen Gruppengröße/Besatzdichte und Produktivität sind dagegen vielfach vorhanden (Gehlbach et al., 1966; Randolph et al., 1981; Petherick et al., 1989; Beattie et al., 1995; Gonyou \& Stricklin, 1998; Turner et al., 2000; Wolter et al., 2000; Turner et al., 2001; Wolter et al., 2001; DeDecker, 2003). Die Resultate dieser Studien sind nicht konsistent. Während Petherick et al. (1989) und Wolter et al. (2001) verringerte tägliche Zunahmen in großen (> 50 Schweine/Bucht) im Vergleich zu kleinen Gruppengrößen beobachtet haben, stellten Randolph et al. (1981) keine Unterschiede zwischen unterschiedlichen Gruppengrößen fest.

Die wenigen Studien zum Zusammenhang zwischen Gruppengröße und Tierwohl betrachten vorwiegend nur einzelne Teilaspekte. So wurde der Zusammenhang zwischen Gruppengröße und Tierwohlindikatoren wie z.B. Kannibalismus oder agonistische Verhaltensweisen untersucht. Velarde \& Geers (2007) stellten fest, dass mit zunehmender Gruppengröße die Anzahl potentieller Rangkämpfe steigt und damit das Verletzungsrisiko um ein vielfaches höher ist. McGlone \& Newby (1994) beobachteten, dass die Verletzungs- und Erkrankungsrate für Schweine in Gruppen mit mehr als 40 Schweinen größer ist als in Gruppen mit 10 oder 20 Tieren pro Bucht. Im Gegensatz dazu konnten Samarakone \& Gonyou (2008) keine Unterschiede bezüglich der Mortalität, der Morbidität und dem Vorkommen von Verhaltensstörungen wie Schwanzbeißen, bei unterschiedlichen Gruppengrößen von 20 bis 100 Schweinen pro Bucht feststellen. Moinard et al. (2003) konnte die Gruppengröße nicht als Risikofaktor für das Auftreten von Schwanzbeißen identifizieren. Die Meta-Analyse von Averós et al. (2010) liefert ebenfalls keinen Beweis dafür, dass unterschiedliche Gruppengrößen einen Einfluss auf das Liegeverhalten von Schweinen haben. 


\section{Literaturverzeichnis}

Averós X., Brossard L., Dourmad J.Y., de Greef K.H., Edge H.L., Edwards S.A. \& Meunier-Salaün M.C. 2010. Quantitative assessment of the effects of space allowance, group size and floor characteristics on the lying behaviour of growing-finishing pigs. Animal 4: 777-783

Baptista F.M., Alban L., Nielsen L.R., Domingos I., Pomba C. \& Almeida V. 2010. Use of herd information for predicting salmonella status in pig herds. Zoonoses and Public Health 57: 49-59

Bartussek H. 1996. Tiergerechtheitsindex für Rinder TGI 35. Bayerische Anstalt für Landwirtschaft, Gumpenstein

Baugesetzbuch 2015. Baugesetzbuch in der Fassung der Bekanntmachung vom 23. September 2004 (BGBI. I S. 2414), das durch Artikel 6 des Gesetzes vom 20. Oktober 2015 (BGBI. I S. 1722) geändert worden ist.

Beattie V.E., Walker N. \& Sneddon I.A. 1995. Effects of Environmental Enrichment on Behaviour and Productivity of Growing Pigs. Animal Welfare 4: 207-220

Beckhove J. 2008. Zukunft der Veredlungswirtschaft: Perspektiven des Schweinemarktes: ISN - Schlachthofvergleich. In Zukunftsperspektiven der Fleischwirtschaft: Verbraucher, Märkte, Geschäftsbeziehungen, Universitätsverlag Göttingen, Göttingen, 61-73

Blokhuis H. 2008. International cooperation in animal welfare: the Welfare Quality® project. Acta Veterinaria Scandinavica 50: 10-18

Blokhuis H.J., Jones R.B., Geers R., Miele M. \& Veissier I. 2003. Measuring and monitoring animal welfare: transparency in the food product quality chain. Animal Welfare 12: 445-455 
Botreau R., Bonde M., Butterworth A., Perny P., Bracke M.B., Capdeville J. \& Veissier I. 2007a. Aggregation of measures to produce an overall assessment of animal welfare. Part 1: a review of existing methods. Animal 1: 1179-1187

Botreau R., Veissier I., Butterworth A., Bracke M.B.M. \& Keeling L.J. 2007b. Definition of criteria for overall assessment of animal welfare. Animal Welfare 16: 225-235

Broens E.M., Graat E.A.M., Van Der Wolf P.J., Van De Giessen A.W. \& De Jong M.C.M. 2011. Prevalence and risk factor analysis of livestock associated MRSA-positive pig herds in The Netherlands. Preventive Veterinary Medicine 102: 41-49

Broom D.M. \& Fraser A.F. 2007. Domestic animal behaviour and welfare Edition t. [Hrsg.]: Centre for Agricultural Bioscience International. Wallimgford, United Kingdom.

Bundes-Immissionsschutzgesetz 2013. Gesetz zum Schutz vor schädlichen Umwelteinwirkungen durch Luftverunreinigungen, Geräusche, Erschütterungen und ähnliche Vorgänge (BundesImmissionsschutzgesetz-BImSchG) in der Fassung der Bekanntmachung vom 17. Mai 2013 (BGBI. I S. 1274).

Busch M.E. \& Wachmann H. 2011. Osteochondrosis of the elbow joint in finishing pigs from three herds: Associations among different types of joint changes and between osteochondrosis and growth rate. The Veterinary Journal 188: 197-203

Carstensen B. \& Christensen J. 1998. Herd size and sero-prevalence of Salmonella enterica in Danish swine herds: a random-effects model for register data. Preventive Veterinary Medicine 34: 191-203 
D'Eath R.B., Arnott G., Turner S.P., Jensen T., Lahrmann H.P., Busch M.E., Niemi J.K., Lawrence A.B. \& Sandoe P. 2014. Injurious tail biting in pigs: how can it be controlled in existing systems without tail docking? Animal 8: $1479-1497$

DeDecker J.M.E., Bradley F. Wolter, Brendan P. Corrigan, Stanley E. Curtis, Gilbert R. Hollis 2003. The effect of group size/floor-space allowance on pig performance in a wean-to-finish production system. Swine Research Reports - 2003

Duncan I.J.H. \& Fraser D. 1997. Understanding animal welfare. In Animal Welfare, Wallimgford, United Kingdom, 19-31

EFSA 2005. The welfare of weaners and rearing pigs: effects of different space allowances and floor types. The EFSA Journal 268: 1-19

EFSA 2007a. Animal health and welfare in fattening pigs in relation to housing and husbandry. The EFSA Journal 564: 1-14

EFSA 2007b. The risks associated with tail biting in pigs and possible means to reduce the need for tail docking considering the different housing and husbandry systems. The EFSA Journal 611: 1-13

Enoe C., Mousing J., Schirmer A.L. \& Willeberg P. 2002. Infectious and rearingsystem related risk factors for chronic pleuritis in slaughter pigs. Preventive Veterinary Medicine 30: 337-349

FAWC 1992. Farm Animal Welfare Council updates the Five Freedoms. Veterinary Record 131: 357

Gardner I.A., Willeberg P. \& Mousing J. 2002. Empirical and theoretical evidence for herd size as a risk factor for swine diseases. Animal Health Research Reviews 3: 43-55 
Gehlbach G.D., Becker D.E., Cox J.L., Harmon B.G. \& Jensen A.H. 1966. Effects of Floor Space Allowance and Number per Group on Performance of Growing-Finishing Swine. Journal of Animal Science 25: 386-391

Gillman C.E., KilBride A.L., Ossent P. \& Green L.E. 2008. A cross-sectional study of the prevalence and associated risk factors for bursitis in weaner, grower and finisher pigs from 93 commercial farms in England. Preventive Veterinary Medicine 83: 308-322

Gonyou H.W. \& Stricklin W.R. 1998. Effects of floor area allowance and group size on the productivity of growing/finishing pigs. Journal of Animal Science 76: 1326-1330

Gonyou H.W. 2001. The social behaviour of pigs. In Social behaviour in farm animals CABI Publishing, Wallingford, United Kingdom, 147-176

Grøntvedt C.A., Er C., Gjerset B., Hauge A.G., Brun E., Jørgensen A., Lium B. \& Framstad T. 2013. Influenza $A(H 1 N 1) p d m 09$ virus infection in Norwegian swine herds 2009/10: The risk of human to swine transmission. Preventive Veterinary Medicine 110: 429-434

Grosse Beilage E., Rohde N. \& Krieter J. 2009. Seroprevalence and risk factors associated with seropositivity in sows from 67 herds in north-west Germany infected with Mycoplasma hyopneumoniae. Preventive Veterinary Medicine 88: 255-263

Hoy S., Gauly M. \& Krieter J. 2006. Nutztierhaltung und -hygiene, Grundwissen Bachelor. Ulmer Eugen Verlag, Stuttgart, Germany, 125-133

Ingenbleek P.T.M., Immink V.M., Spoolder H.A.M., Bokma M.H. \& Keeling L.J. 2012. EU animal welfare policy: Developing a comprehensive policy framework. Food Policy 37: 690-699 
Johnsen P.F., Johannesson T. \& Sandøe P. 2001. Assessment of farm animal welfare at herd level: Many Goals, Many Methods. Acta Agriculturae Scandinavica 51: 26-33

Knage-Rasmussen K.M., Sørensen J.T., Rousing T. \& Houe H. 2013. No association between sow and slaughter pig herd size and animal welfare index based on on-farm welfare assessment. "Does big mean bad? The science behind large scale production". Roslin Institut, University Edinburgh United Kingdom.

Knierim U. 1998. Wissenschaftliche Untersuchungsmethoden zur Beurteilung der Tiergerechtheit. In Beurteilung der Tiergerechtheit von Haltungssystemen, Landwirtschaftsverlag, Münster- Hiltrup, 40-50

Knierim U. 2002. Grundsätzliche ethologische Überlegungen zur Beurteilung der Tiergerechtheit bei Nutztieren. Deutsche Tierärztliche Wochenschrift 109: $261-266$

Knierim U. \& Winckler C. 2009. On-farm welfare assessment in cattle: validity, reliability and feasibility issues and future perspectives with special regard to the Welfare Quality ${ }^{\circledR}$ approach. Animal Welfare 18: 451-458

Knierim U. 2010. Ansätze aus dem EU-Projekt Welfare Quality® zur Beurteilung des Wohlergehens landwirtschaftlicher Nutztiere. Vorträge und Kurzfassungen: Aktuelle Probleme des Tierschutzes. 30. Fortbildungsveranstaltung der ATF-Fachgruppe Tierschutz des Institutes für Tierhygiene, Tierschutz und Nutztierethologie. Tierärztliche Hochschule, Hannover, 7-12

Lawrence A. 2013. Can large intensive systems match the 5 Freedoms for pigs? Roslin Institut, University Edinburgh „Does big mean bad? The science behind large scale production" Edinburgh, United Kingdom. 
Lebret B., Ecolan P., Bonhomme N., Méteau K. \& Prunier A. 2015. Influence of production system in local and conventional pig breeds on stress indicators at slaughter, muscle and meat traits and pork eating quality. Animal 9: 1404-1413

Lo Fo Wong D.M.A., Dahl J., Stege H., van der Wolf P.J., Leontides L., von Altrock A. \& Thorberg B.M. 2004. Herd-level risk factors for subclinical Salmonella infection in European finishing-pig herds. Preventive Veterinary Medicine 62: 253-266

Maes D., Maes H., Deluyker M., Verdonck F., Castryck C., Miry B., Vrijens A. \& de K. 2000. Herd factors associated with the seroprevalencesof four major respiratory pathogens in slaughter pigs from farrow-to-finish pig herds. Veterinary research 31: 313-327

Maes D., Segales J., Meyns T., Sibila M., Pieters M. \& Haesebrouck F. 2008. Control of Mycoplasma hyopneumoniae infections in pigs. Veterinary Microbiology 126: 297-309

McGlone J. \& Newby B. 1994. Space requirements for finishing pigs in confinement: behavior and performance while group size and space vary. Applied Animal Behaviour Science 39: 331-338

Miele M., Veissier I., Evans A. \& Botreau R. 2011. Animal welfare: establishing a dialogue between science and society. Animal Welfare 20: 103-117

Moinard C., Mendl M., Nicol C.J. \& Green L.E. 2003. A case control study of onfarm risk factors for tail biting in pigs. Applied Animal Behaviour Science 81: 333-355

Mousing J., Jensen P.T., Halgaard C., Bager F., Feld N., Nielsen B., Nielsen J.P. \& Bech-Nielsen S. 1997. Nation-wide Salmonella enterica surveillance and control in Danish slaughter swine herds. Preventive Veterinary Medicine 29: 247-261 
Mouttotou N., Hatchell F. \& Green L. 1998. Adventitious bursitis of the hock in finishing pigs: prevalence, distribution and association with floor type and foot lesions. Vet Rec 142: 109-114

Nathues H., Chang Y.M., Wieland B., Rechter G., Spergser J., Rosengarten R., Kreienbrock L. \& Grosse Beilage E. 2012. Herd-Level Risk Factors for the Seropositivity to Mycoplasma hyopneumoniae and the Occurrence of Enzootic Pneumonia Among Fattening Pigs in Areas of Endemic Infection and High Pig Density. Transboundary and Emerging Diseases: 316-328

Petherick J.C., Beattie A.W. \& Bodero D.A.V. 1989. The effect of group size on the performance of growing pigs. Animal Science 49: 497-502

Randolph J.H., Cromwell G.L., Stahly T.S. \& Kratzer D.D. 1981. Effects of group size and space allowance on performance and behavior of swine. Journal of Animal Science 53: 922-927

Samarakone T.S. \& Gonyou H.W. 2008. Productivity and aggression at grouping of grower-finisher pigs in large groups. Canadian Journal of Animal Science 88: 9-17

Sanftleben P., Knierim U., Herrmann H.-J., Müller C. \& von Borell E. 2007. Kritische Kontrollpunkte (CCP) in der Milchrinderhaltung. Züchtungskunde 79: 339-362

Schmolke S.A., Li Y.Z. \& Gonyou H.W. 2003. Effect of group size on performance of growing-finishing pigs. Journal of Animal Science 81: 874-878

Schrøder-Petersen D.L. \& Simonsen H.B. 2001. Tail biting in pigs. The Veterinary Journal 162: 196-210 
Schröder M.J.A. \& McEachern M.G. 2004. Consumer value conflicts surrounding ethical food purchase decisions: a focus on animal welfare. International Journal of Consumer Studies 28: 168-177

Scott E.M., Nolan A.M. \& Fitzpatrick J.L. 2001. Conceptual and methodological issues related to welfare assessment: a framework for measurement. Acta Agriculturae Scandinavica, Section A, Animal Science 30: 5-10

Statista 2015. Selbstversorgungsgrad bei Schweinefleisch in Deutschland in den Jahren 2006 bis $2014 . \quad$ Internetauftritt: http://de.statista.com/statistik/daten/studie/76637/umfrage/selbstversorgu ngsgrad-bei-fleisch-in-deutschland/, Zugriff am 18.11.2015.

Statistisches Bundesamt 2014. Viehhaltung der Betriebe. Landwirtschaftszählung. Agrarstrukturerhebung. Fachserie 3 Reihe 2.1.3. Statistisches Bundesamt (Destatis), Wiesbaden.

Sundrum A. 1998. Zur Beurteilung der Tiergerechtheit von Haltungsbedingungen landwirtschaftlicher Nutztiere. Deutsche Tierärztliche Wochenschrift 105: 65-72

Sutherland M.A., Bryer P.J., Krebs N. \& McGlone J.J. 2008. Tail docking in pigs: acute physiological and behavioural responses. Animal 2: 292-297

Taylor N., Parker R., Mendl M., Edwards S.A. \& Main D.C.J. 2012. Prevalence of risk factors for tail biting on commercial farms and intervention strategies. The Veterinary Journal 194: 77-83

Temple D., Dalmau A., Ruiz de la Torre J., Manteca X. \& Velarde A. 2011. Application of the Welfare Quality $®$ protocol to assess growing pigs kept under intensive conditions in Spain. Journal of Veterinary Behaviour: Clinical Applications and Research 6: 138-149 
Thays Sonoda L., Fels M., Oczak M., Vranken E., Ismayilova G., Guarino M., Viazzi S., Bahr C., Berckmans D. \& Hartung J. 2013. Tail biting in pigs causes and management intervention strategies to reduce the behavioural disorder. A review. Berliner und Münchener Tierärztliche Wochenschrift 126: 104-112

Tierschutz-Nutztierhaltungsverordnung 2006. Verordnung zum Schutz landwirtschaftlicher Nutztiere und anderer zur Erzeugung tierischer Produkte gehaltener Tiere bei ihrer Haltung (TierschutzNutztierhaltungsverordnung - TierSchNutztV) in der Fassung der Bekanntmachung vom 22. August 2006, Bundesgesetzblatt Jahrgang 2006 Teil I Nr. 41, ausgegeben zu Bonn, Germany, am 31. August 2006, (BGBI. I S. 2053).

Tierschutzgesetz 2006. Tierschutzgesetz in der Fassung der Bekanntmachung vom 18. Mai 2006 (BGBI. I S. 1206, 1313), das durch Artikel 3 des Gesetzes vom 28. Juli 2014 (BGBI. I S. 1308) geändert worden ist.

Tönepöhl B., Appel A.K., Welp S., Voß B., König von Borstel U. \& Gauly M. 2012. Effect of marginal environmental and social enrichment during rearing on pigs' reactions to novelty, conspecifics and handling. Applied Animal Behaviour Science 140: 137-145

Tschanz B. 1985. Kriterien für die Beurteilung von Haltungssystemen für landwirtschaftliche Nutztiere aus ethologischer Sicht. Tierärztliche Umschau 40: 730-738

Turner S.P., Ewen M., Rooke J.A. \& Edwards S.A. 2000. The effect of space allowance on performance, aggression and immune competence of growing pigs housed on straw deep-litter at different group sizes. Livestock Production Science 66: 47-55 
Turner S.P., Horgan G.W. \& Edwards S.A. 2001. Effect of social group size on aggressive behaviour between unacquainted domestic pigs. Applied Animal Behaviour Science 74: 203-215

Turner S.P. \& Edwards S.A. 2004. Housing immature domestic pigs in large social groups: implications for social organisation in a hierarchical society. Applied Animal Behaviour Science 87: 239-253

Turner S.P., Farnworth M.J., White I.M.S., Brotherstone S., Mendl M., Knap P., Penny P. \& Lawrence A.B. 2006. The accumulation of skin lesions and their use as a predictor of individual aggressiveness in pigs. Applied Animal Behaviour Science 96: 245-259

Van de Weerd H.A. \& Day J.E.L. 2009. A review of environmental enrichment for pigs housed in intensive housing systems. Applied Animal Behaviour Science 116: 1-20

Van der Wolf P.J. 2001. Herd level husbandry factors associated with the serological Salmonella prevalence in finishing pig herds in The Netherlands. Veterinary Microbiology 78: 205-219

Vanhonacker F., Verbeke W., Van Poucke E., Buijs S. \& Tuyttens F.A.M. 2009. Societal concern related to stocking density, pen size and group size in farm animal production. Livestock Science 123: 16-22

Vanhonacker F., Van Poucke E., Tuyttens F. \& Verbeke W. 2010. Citizens' Views on Farm Animal Welfare and Related Information Provision: Exploratory Insights from Flanders, Belgium. Journal of Agricultural and Environmental Ethics 23: 551-569

Velarde A. \& Geers R. 2007. On farm monitoring of pig welfare. Wageningen Academic, Wageningen, Netherlands, 53-121

Velarde A., Fabrega E., Blanco-Penedo I. \& Dalmau A. 2015. Animal welfare towards sustainability in pork meat production. Meat Science 109: 13-17 
Von Alvensleben R. 2003. Gesellschaft und Tierproduktion. In: Perspektiven in der Tierproduktion. Landbauforschung Völkenrode Sonderheft 263: 1521

Von Borell E., Gauly M., Herrmann H.-J., Hesse D., Knierim U., Müller C., Pelzer A., Schrader L. \& Sürie C. 2012. Tiergerechtheit auf dem Prüfstand. Anforderungen an freiwillige Prüfverfahren gemäß §13a TierSchG (2. Auflage). 383 DLG-Merkblatt, Frankfurt am Main,

Waiblinger S., Boivin X., Pedersen V., Tosi M.-V., Janczak A.M., Visser E.K. \& Jones R.B. 2006. Assessing the human-animal relationship in farmed species: A critical review. Applied Animal Behaviour Science 101: 185242

WBA 2015. Wissenschaftlicher Beirat für Agrarpolitik: Wege zu einer gesellschaftlich akzeptierten Nutztierhaltung - Gutachten des Wissenschaftlicher Beirats für Agrarpolitik beim BMEL. Grethe $H$., Christen O., Balmann A., Baushus J., Birner R., Bokelmann W., Gauly M., Knierim U., Latacz-Lohmann U., Nieberg H., Quaim M., Spiller A., Taube F., Weingarten P., Martinez J., Tenhagen B. U. Entenmann S., Berlin: 89-119

Welfare Quality® 2009. Welfare Quality ${ }^{\circledR}$ assessment protocol for pigs (sow and piglets, growing and finishing pigs). Welfare Quality ${ }^{\circledR}$ Consortium, Lelystad, The Netherlands

Windhorst H.-W. 2002. Wettbewerbsfähigkeit der deutschen Schweinefleischproduzenten im europäischen und globalen Rahmen. In Perspektiven für die Erzeugung von Lebensmitteln tierischer Herkunft in Europa, 19. Hülsenberger Gespräche 2002, Travemünde, 80-88 
Windhorst H.-W. 2008. Die Stellung der deutschen Fleischwirtschaft im europäischen und globalen Rahmen. In Zukunftsperspektiven der Fleischwirtschaft: Verbraucher, Märkte, Geschäftsbeziehungen, Universitätsverlag Göttingen, Göttingen, 3-30

Windhorst H.-W. \& Bräule H. 2011. Analyse zu Strukturen und Entwicklungen in der Schweine- und Sauenhaltung in Deutschland. Universität Vechta, Mitteilungen 77: 10-22

Wolter B.F., Ellis M., Curtis S.E., Parr E.N. \& Webel D.M. 2000. Group size and floor-space allowance can affect weanling-pig performance. Journal of Animal Science 78: 2062-2067

Wolter B.F., Ellis M., Curtis S.E., Augspurger N.R., Hamilton D.N., Parr E.N. \& Webel D.M. 2001. Effect of group size on pig performance in a wean-tofinish production system. Journal of Animal Science 79: 1067-1073

Zheng D.M., Bonde M. \& Sørensen J.T. 2007. Associations between the proportion of Salmonella seropositive slaughter pigs and the presence of herd level risk factors for introduction and transmission of Salmonella in 34 Danish organic, outdoor (non-organic) and indoor finishing-pig farms. Livestock Science 106: 189-199 


\section{KAPITEL 3}

Welfare Quality ${ }^{\circledR}$ assessment in intensive fattening pig farms in Germany: Does herd size have an impact?

Livestock Science

Under Review 
WELFARE QUALITY® ASSESSMENT IN INTENSIVE FATTENING PIG FARMS IN GERMANY:

DOES HERD SIZE HAVE AN IMPACT?

Welfare Quality ${ }^{\circledR}$ assessment in intensive fattening pig farms in Germany: Does herd size have an impact?

S. E. K. Meyer-Hamme ${ }^{1}$, C. Lambertz ${ }^{2}$, M. Gauly²

${ }^{1}$ Department of Animal Sciences, Georg-August-University, Albrecht-Thaer-

Weg 3, 37075 Göttingen, Germany

${ }^{2}$ Faculty of Science and Technology, Free University of Bozen-Bolzano,

Universitätsplatz 5, 39100 Bolzano, Italy 


\section{Abstract}

The pig fattening industry has been recently under serious discussion mainly due to animal welfare concerns. Primarily, large production units have been often criticized, though scientifically-based knowledge on the animal welfare status in these systems is still lacking. Therefore, the aim of this study was to assess the relationship between different herd sizes and the welfare level of fattening pig farms in Germany. In total, 60 farms were assessed using the Welfare Quality $®$ protocol for pigs. Farms were classified according to their herd size into small $(<1,500$ pigs/farm), medium $(1,500-3,000$ pigs/farm) and large (> 3,000 pigs/farm) with 20 farms in each class. Multiple Generalized Linear Mixed Models were used to evaluate differences between herd sizes. While none of the farms were classified as "excellent" or "not classified", $80 \%$ of the farms achieved "enhanced" and the remaining 20\% "acceptable" independent of the herd size. Herd sizes did also not differ in terms of the four principles "good feeding", "good housing", "good health" and "appropriate behaviour". Among the 12 criteria of the Welfare Quality ${ }^{\circledR}$ protocol, a tendency for a superior score in small compared with medium and large herds was only found for "absence of diseases" caused by the fact that the incidence of pneumonia was lower in small $(4.2 \%)$ than in medium (11.6\%) and large herds (10.7\%). Overall, moderate bursitis $(35 \%)$ was found as the most prevalent indicator of welfarerelated problems without a difference between herd sizes $(P>0.05)$. Moderate manure $(15.5 \%)$ was the second most common indicator of poor welfare, while the prevalence increased with herd size. Moderate wounds were detected at a rate of $10.5 \%$ independently of herd size. Tail biting was observed at very low rates, given that all pigs were tail-docked. In conclusion, findings of this preliminary study showed that none of the herd sizes proved to be clearly superior to others in terms of animal welfare. Nevertheless, the overall welfare level of the studied farms has to be considered as low. Further studies should also focus on issues such as the management (e.g. care of animals, health 
check, hygiene regime and climate management), feeding system and floor type to substantiate the present findings.

Keywords: fattening pigs; herd size; Welfare Quality ${ }^{\circledR}$ assessment protocol

\section{Introduction}

Designed to optimize management and increase efficiency, modern pig fattening facilities are generally characterized as large production units (Turner et al., 2003; FAWC, 2012). Standard indoor barns are generally equipped with fully slatted floors, forced ventilation and an automatic feeding system (Hoy et al., 2006). Recently, these production conditions have been under serious discussion among farmers, consumers, media, animal-rights activists, veterinarians, and actors from the industry mainly due to animal welfare concerns (Kayser et al., 2012; Velarde et al., 2015). Apart from the fact that there is no clear definition of intensive or industrial farming, scientifically-based knowledge on the effects of varying herd sizes on the animal welfare status is still lacking (Winckler \& Leeb, 2010).

So far, studies mainly focused on the relationship between herd size and health parameters with contradictory results. As proposed by Gardner et al. (2002), animals in large units may on the one hand be at a greater risk of pathogens imported into the farm through purchased animals and transmitted as a high number of potentially susceptible animals is raised together, while on the other hand improved hygiene measures might be implemented on these farms. While Carstensen \& Christensen (1998) reported a higher salmonellosis incidence with increasing herd size, Van der Wolf (2001) found it vice versa. In contrast, no herd size effect was found for salmonellosis by Zheng et al. (2007) and Baptista et al. (2010) as well as for respiratory diseases, i.e. enzootic pneumonia and influenza, by Maes et al. (2008) and Grøntvedt et al. (2013). Studies investigating the effect of herd size on animal welfare are rare and only focused on a very limited number of welfare indicators. Knage-Rasmussen et al. 
(2013), for example, did not find any relationship between herd size (120 to $7,825 \mathrm{pigs} / \mathrm{farm}$ ) and the expression of normal behaviour and health parameters. Also, the occurrence of tail biting, one of the major welfare problems in pig fattening, did not differ between farm sizes (500 to 7,500 pigs/farm) (Moinard et al., 2003). Generally, comparisons between studies are difficult due to widely variable study designs, country-specific production and environmental conditions, and studied welfare indicators.

As an adequate assessment tool, the Welfare Quality ${ }^{\circledR}$ assessment protocol (Welfare Quality $®$, 2009) was developed. Because the welfare status of animals is multi-factorial, a combination of various parameters is necessary for its evaluation (Blokhuis et al., 2003). In the protocol, animal welfare is defined as a multidimensional concept consisting of the absence of thirst, hunger, discomfort, disease, pain and injuries, stress and the expression of normal behaviour (Veissier, 2007). It is widely accepted by stakeholders and researchers (Blokhuis et al., 2013). For growing pigs raised under intensive conditions only minor differences between farms were found (Temple et al., 2011a; Temple et al., 2012). But, effects of varying herd sizes on the animal well-being of fattening pigs were not assessed, yet.

Therefore, the aim of this study was to assess the relationship between different herd sizes and the welfare level of fattening pig farms. In total, 60 conventional fattening pig farms, with sizes ranging from 250 to 11,000 pigs per farm, were assessed using the WQP.

\section{Material and methods}

\section{Farms and animals}

A total of 60 conventional pig fattening farms, located in Northern Germany, were assessed using the WQP. The farm acquisition was organised with the help of the Association of Pig Farmers in Germany (ISN e.V.). Only conventional full-time farms with indoor barns, equipped with fully or partly slatted concrete floors, forced ventilation system, automatic feeding systems 
and "all in all out" management were included. Participation was voluntary, with all farms being members of the mentioned association.

Data collection was performed between September 2013 and June 2014 by one single assessor, who received intensive training on the correct application of the protocol beforehand. Assessment on all farms started in the morning. The assessor was trained in the theory and practice of the WQP by two persons, who participated in a training session held by experienced trainers of the Welfare Quality ${ }^{\circledR}$ Network group. Intensive on-farm training was done and agreement between observers was obtained during training until a consensus of at least $80 \%$ between the observer and the two trainers was reached.

The size of the farms ranged from 250 to 11,000 pigs. Farm size was defined as the number of pigs raised at the same location (Report of the agricultural policy advisory council, 2015). Three farm size categories were defined: 1) small: < 1,500 pigs/farm; 2) medium: 1,500 to 3,000 pigs/farm; and 3) large: $>3,000$ pigs/farm. Each category consisted of 20 farms. Categories were defined under consideration of the development of farm sizes in the pig production industry in Germany in recent years according to the federal statistical office (Statistisches Bundesamt, 2014) and in accordance with the classification of pig farms by the German Federal Pollution Protection Act (Bundes-Immissionsschutzgesetz, 2013). Eighty $\%$ of the farms only fattened pigs, while $20 \%$ had a closed system raising sows, piglets and fattening pigs. Animals were raised in pens of 10 to 350 animals. All animals were hybrid breeding pigs with the most common female line being of Danish origin called DanZucht (45\%). Other common lines were from the German federal hybrid breeding program (BHZP) (Ellringen, Germany), Topigs (Senden, Germany), Pig Improvement Company (PIC) (Schleswig, Germany), Hypor (Sittensen, Germany) or JSR Hybrid (Ahaus, Germany). Sows were bred by Al with Pietrain $(73 \%)$ or Duroc $(27 \%)$ semen. All barns were insulated and had different mechanical ventilation systems, namely doorway ventilation, channel ventilation, underfloor extraction, perforated steel plates or wood wool cement boards. Pigs were kept on fully- (92\% of the farms) or partly-slatted $(8 \%)$ concrete floors. Two different feeding systems were 
implemented on the farms (62\% automatic or sensor-controlled liquid feeders; $38 \%$ dry or pulp feeding automats). Pigs entered the fattening farms with a mean body weight of $29.9 \pm 2.8 \mathrm{~kg}$ and were slaughtered at $120.8 \pm 3.5 \mathrm{~kg}$. Boars and female pigs were kept on $15 \%$ of the farms, while two of these farms fattened boars as well as castrated pigs. All other farms raised castrates and females. Tail-docking was performed in all pigs.

\section{Assessment of growing pigs using the Welfare Quality $\AA^{\circledR}$ protocol}

An overview of the principles, criteria and measures that were assessed is presented in Table 1. Briefly, farm-related data (feeding and hygiene management, prevention of diseases, mortality rate, castration and tail docking practices) were gathered by farmer interviews prior to the further assessments. Data on the prevalence of pneumonia, pleurisy, ascites and pericarditis were collected from records of the slaughterhouse over a year. After the assessor completed a tour through all stables of the farm to get an overview of the design of the barns and the herd, 10 pens for the animal-based assessment and the observation points for the behavioural observations, which are described in more detail in the following, were randomly selected. In every pen up to 15 individuals were randomly selected for observation. If pigs of different ages were raised on a farm, pens of all age categories were included. Hospital pens were excluded. Both the pens and the pigs were chosen according to the random principle. Hospital pens not considered. In the majority of the studied pens $(60 \%)$ females and castrates were kept in mixed groups, while boars mixed with females $(6 \%)$ and boars alone $(4 \%)$ were only found exceptionally. In all other pens, males and females were raised separately. 
WELFARE QUALITY® ASSESSMENT IN INTENSIVE FATTENING PIG FARMS IN GERMANY:

DOES HERD SIZE HAVE AN IMPACT?

Table 1: Principles, criteria and indicators of the Welfare Quality $®$ assessment protocol

\begin{tabular}{|c|c|c|c|}
\hline Principle & Cri & & Indicator \\
\hline \multirow{4}{*}{ Good feeding } & 1 & Absence of prolonged hunger & Body condition score \\
\hline & \multirow{3}{*}{2} & \multirow{3}{*}{ Absence of prolonged thirst } & Number of drinking places \\
\hline & & & Functioning of drinkers \\
\hline & & & Cleanliness of drinkers \\
\hline \multirow{6}{*}{ Good housing } & \multirow{2}{*}{3} & \multirow{2}{*}{ Comfort around resting } & Bursitis \\
\hline & & & Manure on the body \\
\hline & & & Huddling \\
\hline & 4 & Thermal comfort & Shivering \\
\hline & & & Panting \\
\hline & 5 & Ease of movement & Space allowance \\
\hline \multirow{18}{*}{ Good health } & \multirow{3}{*}{6} & \multirow{3}{*}{ Absence of injuries } & Lameness \\
\hline & & & Wounds on the body \\
\hline & & & Tail biting \\
\hline & \multirow{13}{*}{7} & \multirow{13}{*}{ Absence of disease } & Mortality \\
\hline & & & Coughing \\
\hline & & & Sneezing \\
\hline & & & Pumping \\
\hline & & & Twisted snouts \\
\hline & & & Rectal prolapse \\
\hline & & & Scouring \\
\hline & & & Skin condition \\
\hline & & & Hernias \\
\hline & & & Pneumonia \\
\hline & & & Pleurisy \\
\hline & & & Pericarditis \\
\hline & & & White spots \\
\hline & \multirow{2}{*}{8} & Absence of pain induced by & Castration \\
\hline & & management procedures & Tail docking \\
\hline \multirow{5}{*}{$\begin{array}{l}\text { Appropriate } \\
\text { behaviour }\end{array}$} & 9 & Expression of social behaviours & Social behaviour \\
\hline & 10 & Expression of other behaviours & Exploratory behaviour \\
\hline & 11 & Good human-animal relationship & Fear of humans \\
\hline & \multirow{2}{*}{12} & \multirow{2}{*}{ Positive emotional state } & Qualitative Behaviour \\
\hline & & & Assessment \\
\hline
\end{tabular}


An overview of the different indicators and their scoring is given in table 2 . Measures were scored on a three point scale $(0=$ absent, $1=$ light affection, 2 = strong affection) or a two point scale $(0=$ absent, $2=$ present $)$. Pigs were individually scored from inside the pen for body condition, bursitis, manure on the body, wounds, tail biting, lameness, laboured breathing, twisted snouts, rectal prolapse, skin condition and hernias. Wounds and manure on the body, skin condition and bursitis were observed only on one side of the pig as there are no significant differences between the right and the left side of the animal with respect to these measures (Courboulay \& Foubert, 2007). Shivering, panting, and huddling were scored before the assessor entered the pen. Huddling was assessed only in resting animals.

Table 2: Indicators of the Welfare Quality ${ }^{\circledR}$ assessment protocol and their scoring

\begin{tabular}{|c|c|c|}
\hline Indicator & Score & Description \\
\hline \multirow[t]{2}{*}{ Body condition } & 0 & Good body condition \\
\hline & 2 & $\begin{array}{l}\text { Poor body condition; pigs with visible spine, hip and pin } \\
\text { bones }\end{array}$ \\
\hline \multirow[t]{2}{*}{ Water supply } & 0 & Function correctly and clean \\
\hline & 2 & Do not function properly/dirty \\
\hline \multirow[t]{3}{*}{ Bursitis } & 0 & No evidence of bursae/swelling \\
\hline & 1 & $\begin{array}{l}\text { Moderate bursitis: several small }(1.5-2.0 \mathrm{~cm}) \text { bursae on } \\
\text { the same leg or one large }(2.0-5.0 \mathrm{~cm}) \text { bursae }\end{array}$ \\
\hline & 2 & $\begin{array}{l}\text { Severe bursitis: several large bursae on the same leg or } \\
\text { one extremely large }(5.0-7.0 \mathrm{~cm}) \text { bursae or any eroded } \\
\text { bursae }\end{array}$ \\
\hline \multirow[t]{3}{*}{ Manure } & 0 & Less than $20 \%$ of the body surface is soiled \\
\hline & 1 & $\begin{array}{l}\text { Moderately soiled body: more than } 20 \% \text { but less than } \\
50 \% \text { of the body surface is soiled with faeces }\end{array}$ \\
\hline & 2 & $\begin{array}{l}\text { Severely soiled body: over } 50 \% \text { of the body surface is } \\
\text { soiled with faeces }\end{array}$ \\
\hline Huddling & 0 & $\begin{array}{l}\text { Pig lying with less than half of its body lying on top of } \\
\text { another pig (only assessed in resting animals and } \\
\text { visually from the corridor) }\end{array}$ \\
\hline
\end{tabular}




\begin{tabular}{|c|c|c|}
\hline & 2 & $\begin{array}{l}\text { Pig lying with more than half of its body lying on top of } \\
\text { another pig }\end{array}$ \\
\hline \multirow[t]{2}{*}{ Panting } & 0 & $\begin{array}{l}\text { Normal breathing (only assessed in resting animals and } \\
\text { visually from the corridor) }\end{array}$ \\
\hline & 2 & Rapid breath in short gasp \\
\hline \multirow[t]{2}{*}{ Shivering } & 0 & $\begin{array}{l}\text { No vibration of any body part (only assessed in resting } \\
\text { animals and visually from the corridor) }\end{array}$ \\
\hline & 2 & $\begin{array}{l}\text { Slow and irregular vibration of any body part, or the body } \\
\text { as whole }\end{array}$ \\
\hline \multirow[t]{3}{*}{ Wounds } & 0 & If all regions of the animal's body have up to four lesions \\
\hline & 1 & Moderately wounded: fife to 10 lesions visible \\
\hline & 2 & $\begin{array}{l}\text { Severely wounded: } 11 \text { lesions are observed on at least } \\
\text { two zones of the body or if any zone has more than } 15 \\
\text { lesions }\end{array}$ \\
\hline \multirow[t]{2}{*}{ Tail biting } & 0 & $\begin{array}{l}\text { No evidence of tail biting, superficial biting but no } \\
\text { evidence of fresh blood or of any swelling }\end{array}$ \\
\hline & 2 & $\begin{array}{l}\text { Bleeding tail and/or swollen infected tail lesion, and/or } \\
\text { part of tail tissue missing and presence of crust }\end{array}$ \\
\hline \multirow[t]{3}{*}{ Lameness } & 0 & Normal gait or difficulty in walking, but still using all legs \\
\hline & 1 & $\begin{array}{l}\text { Severely lame, minimum weight-bearing on the affected } \\
\operatorname{limb}\end{array}$ \\
\hline & 2 & $\begin{array}{l}\text { No weight bearing on the affected limb, or not able to } \\
\text { walk }\end{array}$ \\
\hline \multirow[t]{2}{*}{ Pumping } & 0 & No evidence of laboured breathing \\
\hline & 2 & Evidence of laboured breathing \\
\hline \multirow[t]{3}{*}{ Scouring } & 0 & No liquid manure visible in the pen \\
\hline & 1 & Areas in the pen with some liquid manure visible \\
\hline & 2 & All faeces visible inside the pen is liquid manure \\
\hline \multirow[t]{3}{*}{ Skin condition } & 0 & No evidence of skin inflammation or discoloration \\
\hline & 1 & $\begin{array}{l}\text { Localized skin condition: more than zero, but less than } \\
10 \% \text { of the skin is inflamed, discoloured or spotted }\end{array}$ \\
\hline & 2 & $\begin{array}{l}\text { Widespread skin condition: more than } 10 \% \text { of the skin } \\
\text { has an abnormal colour or texture }\end{array}$ \\
\hline \multirow[t]{3}{*}{ Hernias } & 0 & No hernia/rupture \\
\hline & 1 & $\begin{array}{l}\text { Hernias/ruptures without bleeding lesion or touching the } \\
\text { floor }\end{array}$ \\
\hline & 2 & Hernias/ruptures with bleeding lesion or touching the \\
\hline
\end{tabular}


WELFARE QUALITYß ASSESSMENT IN INTENSIVE FATTENING PIG FARMS IN GERMANY:

DOES HERD SIZE HAVE AN IMPACT?

\begin{tabular}{|c|c|c|}
\hline & & floor \\
\hline \multirow{2}{*}{ Twisted snout } & 0 & No evidence of twisted snouts \\
\hline & 2 & Evidence of twisted snouts \\
\hline \multirow[t]{2}{*}{ Rectal prolapse } & 0 & No evidence of rectal prolapse \\
\hline & 2 & Evidence of rectal prolapse \\
\hline Coughing & $\mathrm{n}$ & Number of coughs per 5 min \\
\hline Sneezing & $\mathrm{n}$ & Number of sneezes per 5 min \\
\hline Human-animal & 0 & No panic response to human presence \\
\hline relationship & 2 & $\begin{array}{l}\text { Panic response: more than } 60 \% \text { of the animal fleeing, } \\
\text { facing away from the observer or huddled in the corner } \\
\text { of the pen }\end{array}$ \\
\hline $\begin{array}{l}\text { Negative social } \\
\text { behaviour }\end{array}$ & $\%$ & $\begin{array}{l}\text { Aggressive behaviour/any behaviour with a response } \\
\text { from the disturbed animal/any tail in mouth behaviour }\end{array}$ \\
\hline $\begin{array}{l}\text { Positive social } \\
\text { behaviour }\end{array}$ & $\%$ & $\begin{array}{l}\text { Sniffing, nosing, licking and moving gently away from the } \\
\text { animal without an aggressive or flight reaction from this } \\
\text { individual }\end{array}$ \\
\hline Pen investigation & $\%$ & Sniffing, nosing, licking all parts of pen \\
\hline $\begin{array}{l}\text { Use of enrichment } \\
\text { material }\end{array}$ & $\%$ & $\begin{array}{l}\text { Exploration of straw and other suitable enrichment } \\
\text { material }\end{array}$ \\
\hline
\end{tabular}

Appropriate behaviour was assessed by means of social and exploratory behaviour, qualitative behaviour assessment (QBA) and human-animal relationship test. In all farms, QBA was carried out at four randomly chosen observation points. At each point, animals were observed for $5 \mathrm{~min}$ after which they were rated on a $125 \mathrm{~mm}$ visual analogue scale with the following 20 adjectives: active, relaxed, fearful, agitated, calm, content, tense, enjoying, frustrated, bored, playful, positively occupied, listless, lively, indifferent, irritable, aimless, happy, distressed and sociable.

Following QBA, social and explanatory behaviour were assessed using the scan sampling method at three randomly chosen observation points of the farm different from the QBA points. For the assessment of the social and exploratory behaviour, all pigs in the pens had to stand up. If necessary, hands were clapped before starting with the observation 5 minutes later. During this time, 
coughing and sneezing was counted and scouring assessed. Afterwards, 40-60 animals were scan-sampled with 2-min intervals for a total of $10 \mathrm{~min}$ at each observation point. Positive social, negative social, pen investigation, use of enrichment material and other active behaviour or resting were differentiated as explained in detail in table 2 .

The human-animal relationship test was performed after entering the pen and walking around it in one direction. Then, the observer waited in the middle of the pen for $30 \mathrm{sec}$, before walking around the pen in the other direction and scoring the animals as given in table 2 .

Furthermore, resource-based parameters such as the number, functioning and cleanliness of the drinkers were recorded. The pen size was measured and the average weight of the animals was calculated using the weight at the start of the fattening period, the length of the fattening period at the assessment and assuming an average weight gain of $800 \mathrm{~g} /$ day to determine the space allowance.

The evaluation of the data was done using the algorithm of the WQP. The overall evaluation on the $0-100$ (range of scores $=0-100$ ) of a farm is rated as "excellent", "enhanced", "acceptable" or "not classified". On the given scale, 0 presents the worst and 100 the best welfare state. In the overall evaluation, the individual criteria within a particular principle do not compensate for each other, thus a high score in one will not compensate for a low score in another. A farm is considered to be "excellent" if it scores more than 55 in all principles and more than 80 in two of them, "enhanced" if it scores more than 20 in all principles and more than 55 in two of them, "acceptable" if it scores more than 10 in all principles and more than 20 in three of them and is "not classified" if this minimum standard is not reached (Welfare Quality ${ }^{\circledR}, 2009$ ). Given that all farms performed tail docking and most of them castration, a maximum score of 8 in farms conducting both handling procedures and 38 in boar farms could have been reached for the criteria "absence of pain induced by management practice". 


\section{Statistical analyses}

The SAS statistical package version 9.3 (SAS Institute Inc., Cary, NC, 2010) was used. The individual animal-based measures were expressed as the number of pigs in the pen having a score of 1 or 2 indicating poor welfare in relation to the total number of pigs evaluated in each pen. The assessed parameters were aggregated to the 12 criteria, four welfare principles and overall assessment as given by the WQP.

Pen was defined as the statistical unit and results were considered statistically significant at $P<0.05$. Multiple Generalized Linear Mixed Models using the GLIMMIX procedure were performed separately for the animal-based parameters, criteria, principles and the overall assessment. A Poisson distribution and a logarithmic link function were assumed. As fixed effect the farm category (small, medium and large) was included. The farm served as random effect to account for the possible dependence between observations of pens from the same farm. Scores are presented as Least Square Means (LSM) and standard error.

Additionally, a Principle Component Analysis (PCA) applying the FACTOR procedure without rotation was performed at the level of the 12 different WQPcriteria in order to highlight the relationship among them. The constitutional theory of this method is that there are underlying principles in the indicators and criteria, respectively, which might influence each other (O'Rourke \& Hatcher, 2013). Single PCAs were applied for each farm size category.

The first two Principle Components (Factor 1 and Factor 2) identified with an Eigenvector of greater than 1.0 were applied. Each criterion achieved a certain factor loading on Factor 1 and Factor 2, which is a dimensionless number between -1 and 1 . The factor loadings quantified the weight each adjective had on the two main axes (Rencher, 2002). Factor loadings greater than or equal to 0.40 were interpreted as highly positive and factor loadings less than or equal to -0.40 as highly negative (O'Rourke \& Hatcher, 2013). The values obtained were plotted in a two dimensional interpretative word chart. 


\section{Results}

Without any of the farms being classified as "excellent" or "not classified", 17, 16 and 15 of the small, medium and large farms achieved the overall WQP evaluation "enhanced", while the remaining farms were classified as "acceptable". The scores for the different criteria and principles separated by herd size are shown in table 3 . Highest values were achieved for the principle "good feeding". This was mainly due to the fact, that only a very limited number of pigs was found with a poor body condition. The criterion "absence of prolonged thirst" was scored more than 10 points lower due to an insufficient number and poor functionality of the drinkers. The number of animals per drinker ranged from 2 to 43 . On $22 \%$ of the farms more than 10 pigs had to share one drinker. Furthermore, in $6.7 \%$ of pens only one drinker for seven to 22 pigs was available. On $38 \%$ of the farms at least one drinker did not function correctly. There were farms with a liquid feeding systems $(n=3)$, which had either no drinkers or turned them off after a certain period of the fattening period, which does not fulfil the legal requirements.

For "good housing", differences between the herd sizes were not significant ( $P$ $>0.05)$. Among the animal-based measures the highest prevalence rate was determined for moderate bursitis (35\%), independent of the herd size $(P>$ $0.05)$. Moderate manure $(16 \%)$ was the second most common measure on the farms. Medium and large herd sizes had a significantly higher occurrence of moderate soiled pigs than small $(P<0.05)$. The mean space allowance was $0.83 \mathrm{~m}^{2} / \mathrm{pig}$ ranging from 0.3 to $2.5 \mathrm{~m}^{2}$. Actually, the space allowance of more than $40 \%$ of the pens was below the German Farm Animal Welfare Regulations (Tierschutz-Nutztierhaltungsverordnung, 2006) and over-crowded pens were found on $92 \%$ of the farms.

Among all principles, "good health" was scored worst. Without differences between herd sizes, moderate wounds $(11 \%)$ were the third most common indicator of poor welfare. Tail biting was only observed at very low rates. The incidence of pneumonia was in tendency lower in small herds $(4.2 \% \pm 2.8)$ than 
WELFARE QUALITY® ASSESSMENT IN INTENSIVE FATTENING PIG FARMS IN GERMANY:

in medium $(11.6 \% \pm 2.8)$ and large herds $(10.7 \% \pm 2.8)(P=0.081)$. The mortality rate averaged $2.5 \%$, ranging between 0.9 and $5.2 \%(P>0.05)$.

Within the principle "appropriate behaviour", low scores for all herd sizes were recorded for the criterion "expression of other behaviours" mainly due to the low investigative behaviour shown by the pigs. 
Table 3: Scores (least square means (LSM), standard error (SE), range) of the principles (bold) and criteria of the Welfare Quality ${ }^{\circledR}$ protocol, separated by farm size (small: < 1,500 pigs/farm, medium: 1,500 to 3,000 pigs/farm and large: > 3,000 pigs/farm)

\begin{tabular}{|c|c|c|c|c|c|c|c|c|c|c|}
\hline \multirow{3}{*}{ Principle/Criteria } & \multicolumn{9}{|c|}{ Farm size } & \multirow{3}{*}{ P-Value } \\
\hline & \multicolumn{3}{|c|}{ Small } & \multicolumn{3}{|c|}{ Medium } & \multicolumn{3}{|c|}{ Large } & \\
\hline & LSM & SE & Range & LSM & SE & Range & LSM & SE & Range & \\
\hline Good feeding & 86.9 & 4.8 & $41.4-100$ & 86.7 & 4.8 & $57.0-100.0$ & 86.6 & 4.8 & $38.3-100.0$ & NS \\
\hline Absence of prolonged hunger & 99.7 & 0.2 & $95.2-100.0$ & 99.8 & 0.2 & $98.4-100.0$ & 99.8 & 0.2 & $98.5-100.0$ & NS \\
\hline Absence of prolonged thirst & 86.5 & 5.1 & $40.0-100.0$ & 87.0 & 5.1 & $55.0-100.0$ & 87.0 & 5.1 & $35.0-100.0$ & NS \\
\hline Good housing & 71.7 & 1.6 & $56.9-81.5$ & 71.3 & 1.6 & $61.2-82.4$ & 70.5 & 1.6 & $54.0-84.3$ & NS \\
\hline Comfort around resting & 69.2 & 2.2 & $48.7-82.9$ & 69.6 & 2.2 & $55.2-80.9$ & 66.4 & 2.2 & $43.3-87.6$ & NS \\
\hline Thermal comfort & 100.0 & 1.2 & $100.0-100.0$ & 98.0 & 1.2 & $59.0-100.0$ & 100.0 & 1.2 & $100.0-100.0$ & NS \\
\hline Ease of movement & 73.0 & 1.7 & $59.7-88.6$ & 71.0 & 1.7 & $56.8-86.6$ & 75.7 & 1.7 & $60.3-87.4$ & NS \\
\hline Good health & 29.8 & 1.9 & $20.1-38.4$ & 28.2 & 1.9 & $16.8-48.9$ & 29.4 & 1.9 & $18.3-48.8$ & NS \\
\hline Absence of injures & 84.3 & 2.3 & $65.5-98.4$ & 87.6 & 2.3 & $59.6-99.7$ & 89.9 & 2.3 & $66.8-99.2$ & NS \\
\hline Absence of diseases & 71.4 & 4.7 & 29.0-100.0 & 56.3 & 4.7 & $29.0-100.0$ & 64.2 & 4.7 & $34.1-100.0$ & 0.08 \\
\hline Absence of pain & 11.0 & 2.4 & $8.0-38.0$ & 14.0 & 2.4 & $8.0-38.0$ & 12.5 & 2.4 & $8.0-38.0$ & NS \\
\hline Appropriate behaviour & 30.9 & 1.2 & $21.9-39.9$ & 33.1 & 1.2 & $25.1-46.7$ & 33.7 & 1.2 & $24.9-45.6$ & NS \\
\hline Expression of social behaviour & 52.8 & 3.4 & 29.3-74.6 & 57.1 & 3.4 & $34.4-85.1$ & 61.6 & 3.4 & $30.7-93.3$ & NS \\
\hline Expression of other behaviours & 23.7 & 1.6 & $15.2-38.4$ & 26.8 & 1.6 & $16.4-41.7$ & 26.9 & 1.6 & $13.0-38.7$ & NS \\
\hline Good human-animal relationship & 65.5 & 6.4 & $15.5-100.0$ & 69.0 & 6.4 & $15.5-100.0$ & 75.3 & 6.4 & $30.2-100.0$ & NS \\
\hline Positive emotional state & 37.9 & 2.4 & $15.4-60.1$ & 36.4 & 2.4 & $15.1-53.0$ & 37.0 & 2.4 & $17.0-63.5$ & NS \\
\hline
\end{tabular}

NS = non-significant 
A good agreement, expressed as short distances of the same criteria between farm sizes could not be displayed by the results of the PCA (Figure 1). In the PCA, factor 1 explained $31.0 \%$ and factor 2 another $23.5 \%$ of the total variance. The criteria hunger, diseases and QBA showed high loadings on the first axis independent of the farm size. In contrast, high positive values were shown for resting, movement and pain in medium and large farms, but high negative values for small farms. Regarding axis 2, high positive values were found independent of the farm size for the criteria other as well as social behaviour. In summary, a clear differentiation by farm size was not possible at the level of the different criteria. The PCA at the level of the individual WQP-measures (data not shown) showed a similar heterogeneous distribution for factor 1 and 2 , which explained 26.0 and $20.0 \%$ of the variance, respectively. 


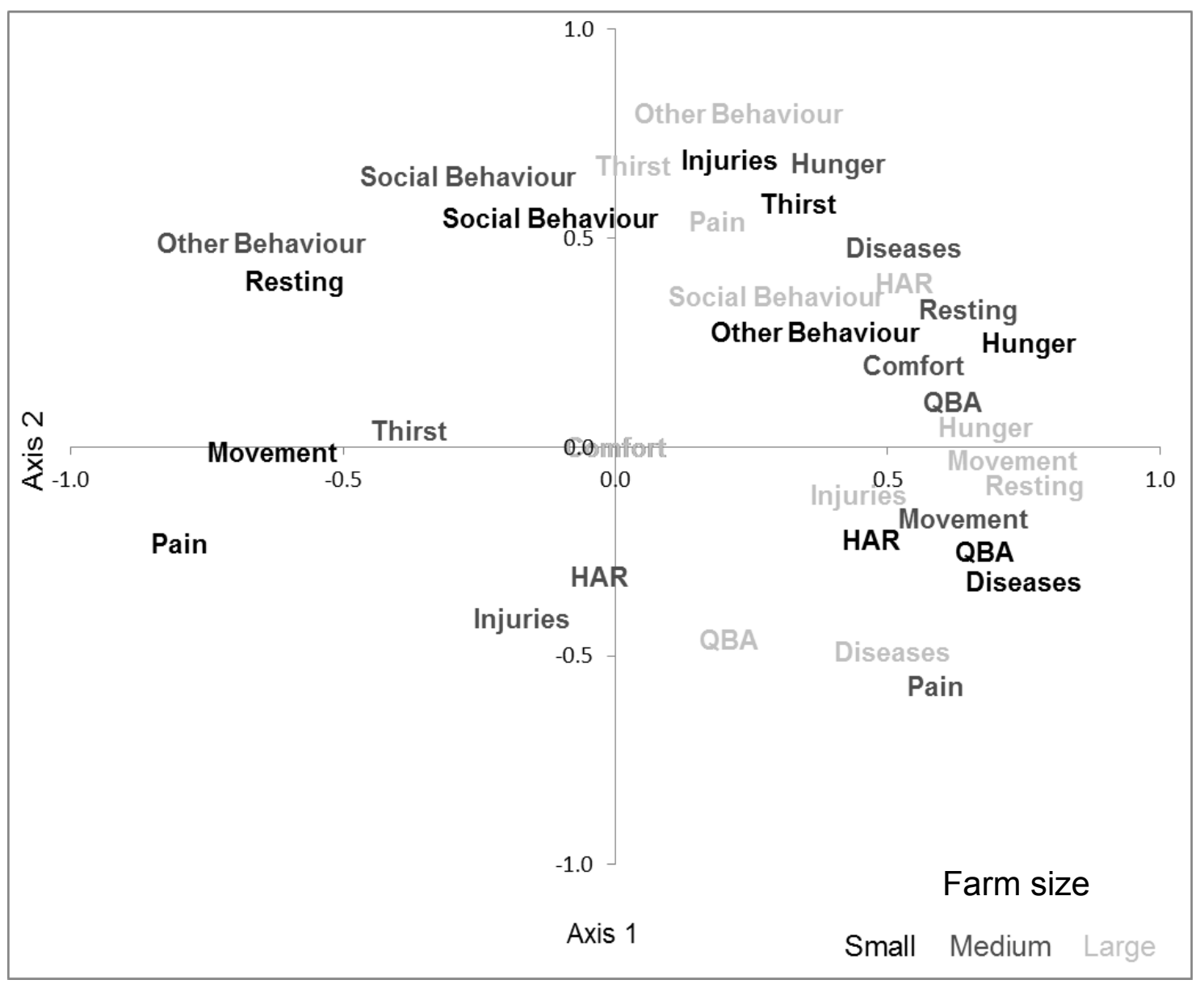

Figure 1: Word chart presenting loadings on factor 1 and 2 of the Principal Component Analysis for the twelve different criteria scores for small (black), medium (dark grey) and large (light grey) farms.

\section{Discussion}

In Germany, the term 'intensive farming' was established following the "Regulation to protect against hazards of animal diseases by keeping pigs" in 1975 being used for farms with more than 1,250 pigs. FAO defined 'intensive livestock farming' as a system in which less than $10 \%$ of the dry matter feed are produced by the farm itself and the stocking density exceeds ten livestock units per hectare of farmland (FAO, 1995). In addition, Kayser et al. (2012) recently demonstrated that German consumers associate the term 'intensive farming' with herd sizes of more than 1,000 pigs per farm. In Germany, the mean herd 
size is 1,037 fattening pigs per farm, whereas approximately $74 \%$ of all pigs are kept in farms with more than 1,000 and $18 \%$ in farms with more than 5,000 fattening places (Statistisches Bundesamt, 2014). Particularly the proportion of the latter category is continually growing mainly in order to optimize management and increase labour efficiency (FAWC, 2012). Thus, farms of this study are representative conventional pig fattening farms in Germany. However, results might be biased by the fact, that all participating farms were members of the Association of German Pig Farmers. Another issue that has to be considered is that several farms (20\%) managed a closed system. In general, closed systems require a higher level of management practice and expertise, which could also impact the way fattening pigs are raised. Another influencing factor, which was not assessed in this study, is the use of employee. At herd sizes of more than 2.000 pigs, farmers generally have to recruit external labour, which are often less skilled and experienced in animal management. So far, this is the first study evaluating the relationship between herd size and animal welfare status. Following, results should give a first overview in the actual welfare debate considering the size of the farms.

In general, the welfare level in the present study has to be considered as low. This is widely in agreement with other recent studies using WQP in pigs and supports the fact that the studied farms were representative for the actual production conditions of fattening pigs. Studying only three intensive fattening pig farms, Otten et al. (2013) found values for the "overall assessment" comparable to our findings. Similar to the results obtained in the pig husbandry, studies on cattle using WQP were also not able to classify farms with "excellent" (Kirchner et al., 2014; Popescu et al., 2014). In terms of herd size, our results confirm those of Knage-Rasmussen et al. (2013), who did not find any relationship between the number of pigs per farm (120 to 7,825 pigs/farm) and a welfare index composed of behavioural measurements and clinical examinations. Otten et al. (2013) also figured out the highest scores the principle "good feeding". Expectedly, pigs under intensive production conditions, which are usually fed ad libitum, very rarely (below $1 \%$ ) show a poor body 
condition (Temple et al., 2012). However, under extensive or straw-bedding conditions, this indicator may become more relevant (Scott et al., 2006). Similar to the occurrence of pigs with a poor body condition, the prevalence of lameness, hernia and skin lesions largely depend on management factors such as medical care and the correct use of hospital pens. However, it has to be mentioned here that hospital pens are not assessed by WQP, thus the actual prevalence's in the studied farms might have been greater. Consequently, the presence of lameness or hernia reflects not only health but also management problems as affected pigs should be separated in hospital pens (Temple et al., 2011a). Supporting our findings, Otten et al. (2013) found an inadequate water supply under comparable production conditions. A sufficient water supply for all pigs should be seen as a first and simple step to improve the welfare level.

Moderate bursitis is a sensitive indicator to compare different production systems and differentiating farms, because of high between-farm variability and low within-farm variability (Temple et al., 2012). First of all, the occurrence of bursitis can be associated with the environment, especially the floor type. A concrete floor increases pressure on the limbs and has an effect on the severity of bursitis (Gillman et al., 2008). Thus, animals raised on concrete floors, especially when fully-slatted, are exposed to a higher risk of bursitis compared with bedded floors, explaining the high prevalence of bursitis under conventional conditions. Pigs in the last period of fattening have a higher risk of bursitis than younger animals, because the greater weight exerts additional pressure of the concrete on the limbs (Gillman et al., 2008). Consequently, the prevalence is not consistent over the whole fattening period (Temple et al., 2013). The prevalence of bursitis was not affected by herd size, which can be mainly explained by the fact that all farms raised animals at different stages of the fattening period. Differences might have become present if all farms would have been assessed at the very end of the fattening period. Values of moderate manure on the body are similar to those of Temple et al. (2011a) of fattening pig farms with concrete floors. The reasons for the occurrence of soiled bodies are multifactorial including mainly environmental factors (Velarde \& Geers, 2007). 
As valid for bursitis, too, the type of floor is a predominant causal factor for dirty pigs in conventional housing systems (Temple et al., 2011a), while on partlyslatted floors the risk is generally higher than on fully-slatted floors (Temple et al., 2012). Consistently, the prevalence of pigs with moderate manure on the body was $13.4 \%$ on fully- and $20.6 \%$ on partly-slatted floors, which were similarly distributed among farm size categories. However, the floor type cannot be used as an exploratory variable in the present study, because more than $90 \%$ of the animals were raised on fully-slatted floors. Besides, another determining factor is the feeding system. Liquid-fed pigs were dirtier than those fed by dry feeders, while the use of liquid feeding systems increased with the number of fattening places. This may partly explain the higher occurrence of dirty pigs in large herds.

Moderate wounds in this study were found more often than by Temple et al. (2011a). In general, it remains questionable whether these wounds are a consequence of social interactions between animals (fights) or deficiencies in the physical environmental (inappropriate design of facilities). Factors that are described in the literature as determining factors for wounds such as sex (Fredriksen et al., 2008) could not be analysed in detail in this study. In general, a higher prevalence of wounds can be expected in pens with boars and castrates (Temple et al., 2012), a dry feeding system (Botermans \& Svendsen, 2000), large group sizes (Velarde \& Geers, 2007), higher stocking density (Turner et al., 2000) and at the beginning of the fattening period (Temple et al., 2013). The low prevalence of tail biting, which was in the range presented by Temple et al. (2012), can be mainly attributed to tail-docking. In fact, it has been shown that docked pigs are less bitten than un-docked pigs (Sutherland et al., 2008), though tail docking does not prevent tail biting completely (Moinard et al., 2003). Because all pigs were tail-docked without anaesthetics, "absence of pain induced by management practice" was scored lower than the other two criteria of that principle. Research studies have shown that tail docking itself can be painful (Van Beirendonck et al., 2012). As the other major practice, castration was performed on most of the farms. Fattening boars seems to be of 
advantage, because there is no more reason for a painful and stressful surgical castration (Rault et al., 2011), but it remains unclear from this study, whether behavioural differences between castrates and boars, that may lead to management and housing problems (Boyle \& Björklund, 2007), may also result in impaired welfare. The low mortality rate indicates that poor animal husbandry and stockman ship were rarely found (Velarde \& Geers, 2007).

According to Van de Weerd \& Day (2009), intensive systems are often criticised with respect to species-specific behaviour, explaining the low score for the principle "appropriate behaviour". The assessment of behaviour involves a greater degree of subjectivity in comparison to the three other principles (Temple et al., 2011b), but it is still useful to include both psychological and physiological parameters in the welfare assessment (Duncan \& Petherick, 1991). In general, behaviour is an important component of animal welfare, because it occurs as a consequence of animal's feeling. The quantification of behaviour has become of considerable interest in the last years, whereby emotions are still difficult to assess with the available methods (Boissy et al., 2007). Furthermore, the interpretation remains complicated due to the complex physiological system involved with emotions (Temple et al., 2011b).

In addition, the very low correlations between the factors of the PCAs of the different animal-based measures emphasize their individual importance for WQP. According to Temple et al. (2012), each indicator should be analysed separately, whereby the weight of each indicator should be directly associated with its impact on welfare. For example, the weight of the indicator bursitis should be lower than for wounds or lameness, which are directly associated with pain (Velarde \& Geers, 2007).

The results of the PCA confirm that the three different herd sizes showed a wide agreement in terms of the indicators and the criteria in terms of short distances between the factor loadings. Given the low proportion of variance explained by the first two factors, it was not possible to differentiate farm categories. In order to identify determining factors on the welfare level of fattening pig farms, further assessments should also take management practices, expertise of the 
stockman, feedings system and floor type into account in association with the farm size.

\section{Conclusion}

Findings of the present study showed that none of the herd sizes $(<1,500 \mathrm{vs}$ $1,500-3,000$ vs $>3,000$ pigs/farm) proved to be superior in terms of animal welfare. Nevertheless, the overall welfare level of the studied farms has to be considered as low. The present findings indicate that the farm size cannot be associated with an impaired animal welfare, though further studies should especially focus on factors such as the management, feedings system or the floor type in combination with the farm size. The high prevalence of bursitis and soiled animals underline the necessity to improve the quality of floors and climate management under practical fattening conditions.

\section{Acknowledgements}

The study was supported by the PhD-Program "Animal Welfare in Intensive Livestock Production Systems" funded by Lower Saxony, Germany. The authors are grateful to Dr. Karl-Heinz Tölle, Dr. Conrad Welp, Dr. Jörg Bauer, Martin Knees, Georg Freisfeld, Gert Stelling and all participating farmers for their cordial collaboration.

\section{References}

Baptista F.M., Alban L., Nielsen L.R., Domingos I., Pomba C. \& Almeida V. 2010. Use of herd information for predicting salmonella status in pig herds. Zoonoses and Public Health 57: 49-59 
Blokhuis H., Jones B., Veissier I. \& Miele M. 2013. Assessing and improving farm animal welfare: the way forward. In Improving farm animal welfare Science and society working together: the Welfare Quality approach, Wageningen Academic Publishers Gelderland, Netherlands, 215-222

Blokhuis H.J., Jones R.B., Geers R., Miele M. \& Veissier I. 2003. Measuring and monitoring animal welfare: transparency in the food product quality chain. Animal Welfare 12: 445-455

Boissy A., Manteuffel G., Jensen M.B., Moe R.O., Spruijt B., Keeling L.J., Winckler C., Forkman B., Dimitrov I., Langbein J., Bakken M., Veissier I. \& Aubert A. 2007. Assessment of positive emotions in animals to improve their welfare. Physiology and Behavior 22: 375-397

Botermans J.A.M. \& Svendsen J. 2000. Effect of feeding environment on performance, injuries and behaviour in growing-finishing pigs: Groupbased studies. Acta Agriculturae Scandinavica 50: 237-249

Boyle L.A. \& Björklund L. 2007. Effects of fattening boars in mixed or single sex groups and split marketing on pig welfare. Animal Welfare 16: 259-262

Bundes-Immissionsschutzgesetz 2013. Gesetz zum Schutz vor schädlichen Umwelteinwirkungen durch Luftverunreinigungen, Geräusche, Erschütterungen und ähnliche Vorgänge (BundesImmissionsschutzgesetz-BImSchG) in der Fassung der Bekanntmachung vom 17. Mai 2013 (BGBI. I S. 1274).

Carstensen B. \& Christensen J. 1998. Herd size and sero-prevalence of Salmonella enterica in Danish swine herds: a random-effects model for register data. Preventive Veterinary Medicine 34: 191-203

Courboulay V. \& Foubert C. 2007. Testing different methods to evaluate pig welfare on farm. Animal Welfare 16: 193-196 
Duncan I.J. \& Petherick J. 1991. The implications of cognitive processes for animal welfare. Journal of Animal Science 69: 5017-5022

FAO 1995. FAO (Food and Agricultural Organization of the United Nations): World Livestock Production Systems. Current status, issues and trends. FAO Animal Production and Health. Paper 127

FAWC 2012. Report on Farm animal welfare: Health and disease. Farm Animal Welfare Committee, Department for Environment, Food and Rural Affairs, London, United Kingdom: 1-72

Fredriksen B., Lium B.M., Marka C.H., Mosveen B. \& Nafstad O. 2008. Entire male pigs in farrow-to-finish pens: Effects on animal welfare. Applied Animal Behaviour Science 110: 258-268

Gardner I.A., Willeberg P. \& Mousing J. 2002. Empirical and theoretical evidence for herd size as a risk factor for swine diseases. Animal Health Research Reviews 3: 43-55

Gillman C.E., KilBride A.L., Ossent P. \& Green L.E. 2008. A cross-sectional study of the prevalence and associated risk factors for bursitis in weaner, grower and finisher pigs from 93 commercial farms in England. Preventive Veterinary Medicine 83: 308-322

Grøntvedt C.A., Er C., Gjerset B., Hauge A.G., Brun E., Jørgensen A., Lium B. \& Framstad T. 2013. Influenza $A(H 1 N 1) p d m 09$ virus infection in Norwegian swine herds 2009/10: The risk of human to swine transmission. Preventive Veterinary Medicine 110: 429-434

Hoy S., Gauly M. \& Krieter J. 2006. Nutztierhaltung und -hygiene, Grundwissen Bachelor. Ulmer Eugen Verlag, Stuttgart, Germany, 125-133 
Kayser M., Schlieker K. \& Spiller A. 2012. Die Wahrnehmung des Begriffs "Massentierhaltung" aus Sicht der Gesellschaft. Berichte über Landwirtschaft 90: 417-427

Kirchner M.K., Schulze Westerath H., Knierim U., Tessitore E., Cozzi G., Pfeiffer C. \& Winckler C. 2014. Application of the Welfare Quality assessment system on European beef bull farms. Animal 8: 827-835

Knage-Rasmussen K.M., Sørensen J.T., Rousing T. \& Houe H. 2013. No association between sow and slaughter pig herd size and animal welfare index based on on-farm welfare assessment. „Does big mean bad? The science behind large scale production". Roslin Institut, University Edinburgh United Kingdom

Maes D., Segales J., Meyns T., Sibila M., Pieters M. \& Haesebrouck F. 2008. Control of Mycoplasma hyopneumoniae infections in pigs. Veterinary Microbiology 126: 297-309

Moinard C., Mendl M., Nicol C.J. \& Green L.E. 2003. A case control study of onfarm risk factors for tail biting in pigs. Applied Animal Behaviour Science 81: $333-355$

O'Rourke N. \& Hatcher L. 2013. Factor Analysis and Structural Equation Modeling. SAS $®$ Institute Inc. Cary, North Carolina, USA.

Otten D., Annas E. \& Van den Weghe H.F.A. 2013. The application of animal welfare standards in intensive production systems using the assessment protocols of Welfare Quality®: Fattening pig husbandry in Northwest Germany. International Journal of Livestock Production 4: 49-59

Popescu S., Borda C., Diugan E.A., Niculae M., Stefan R. \& Sandru C.D. 2014. The effect of the housing system on the welfare quality of dairy cows. Italian Journal of Animal Science 13: 15-22 
Rault J.-L., Lay Jr D.C. \& Marchant-Forde J.N. 2011. Castration induced pain in pigs and other livestock. Applied Animal Behaviour Science 135: 214225

Rencher A.C. 2002. Principal component analysis. Rencher A. C.: Methods of Multivariate Analysis, John Wiley and sons, New York

Report of the agricultural policy advisory council 2015. Report of the agricultural policy advisory council of the German Federal Ministry for Food, Agriculture and Consumer Protection - Bericht des Wissenschaftlichen Beirats der Agrarpolitik: Wege zu einer gesellschaftlich akzeptierten Nutztierhaltung - Gutachten des Wissenschaftlicher Beirats Agrarpolitik beim BMEL. Grethe H., Christen O., Balmann A., Baushus J., Birner R., Bokelmann W., Gauly M., Knierim U., Latacz-Lohmann U., Nieberg H., Quaim M., Spiller A., Taube F., Weingarten P., Martinez J., Tenhagen B. u. Entenmann S., Berlin, 89-119

Scott K., Chennells D.J., Campbell F.M., Hunt B., Armstrong D., Taylor L., Gill B.P. \& Edwards S.A. 2006. The welfare of finishing pigs in two contrasting housing systems: Fully-slatted versus straw-bedded accommodation. Livestock Science 103: 104-115

Statistisches Bundesamt 2014. Viehhaltung der Betriebe. Landwirtschaftszählung. Agrarstrukturerhebung. Fachserie 3 Reihe 2.1.3. Statistisches Bundesamt (Destatis), Wiesbaden.

Sutherland M.A., Bryer P.J., Krebs N. \& McGlone J.J. 2008. Tail docking in pigs: acute physiological and behavioural responses. Animal 2: 292-297

Temple D., Dalmau A., Ruiz de la Torre J., Manteca X. \& Velarde A. 2011a. Application of the Welfare Quality ${ }^{\circledR}$ protocol to assess growing pigs kept under intensive conditions in Spain. Journal of Veterinary Behaviour: Clinical Applications and Research 6: 138-149 
Temple D., Manteca X., Velarde A. \& Dalmau A. 2011b. Assessment of animal welfare through behavioural parameters in Iberian pigs in intensive and extensive conditions. Applied Animal Behaviour Science 131: 29-39

Temple D., Courboulay V., Manteca X., Velarde A. \& Dalmau A. 2012. The welfare of growing pigs in five different production systems: assessment of feeding and housing. Animal 6: 656-667

Temple D., Manteca X., Dalmau A. \& Velarde A. 2013. Assessment of testretest reliability of animal-based measures on growing pig farms. Livestock Science 151: 35-45

Tierschutz-Nutztierhaltungsverordnung 2006. Verordnung zum Schutz landwirtschaftlicher Nutztiere und anderer zur Erzeugung tierischer Produkte gehaltener Tiere bei ihrer Haltung (TierschutzNutztierhaltungsverordnung - TierSchNutztV) in der Fassung der Bekanntmachung vom 22. August 2006, Bundesgesetzblatt Jahrgang 2006 Teil I Nr. 41, ausgegeben zu Bonn, Germany, am 31. August 2006, (BGBI. I S. 2053).

Turner S.P., Ewen M., Rooke J.A. \& Edwards S.A. 2000. The effect of space allowance on performance, aggression and immune competence of growing pigs housed on straw deep-litter at different group sizes. Livestock Production Science 66: 47-55

Turner S.P., Allcroft D.J. \& Edwards S.A. 2003. Housing pigs in large social groups: a review of implications for performance and other economic traits. Livestock Production Science 82: 39-51

Van Beirendonck S., Driessen B., Verbeke G., Permentier L., van de Perre V. \& Geers R. 2012. Improving survival, growth rate, and animal welfare in piglets by avoiding teeth shortening and tail docking. Journal of Veterinary Behavior: Clinical Applications and Research 7: 88-93 
Van de Weerd H.A. \& Day J.E.L. 2009. A review of environmental enrichment for pigs housed in intensive housing systems. Applied Animal Behaviour Science 116: 1-20

Van der Wolf P.J. 2001. Herd level husbandry factors associated with the serological Salmonella prevalence in finishing pig herds in The Netherlands. Veterinary Microbiology 78: 205-219

Veissier I. 2007. Assuring animal welfare: from societal concerns to implementation - Rationale behind the Welfare Quality ${ }^{\circledR}$ assessment of animal welfare. Second Welfare Quality $®$ stakeholder conference, Berlin, Germany, 19-22.

Velarde A. \& Geers R. 2007. On farm monitoring of pig welfare. Wageningen Academic, Wageningen, Netherlands, 53-121

Velarde A., Fabrega E., Blanco-Penedo I. \& Dalmau A. 2015. Animal welfare towards sustainability in pork meat production. Meat Science 109: 13-17

Welfare Quality ${ }^{\circledR}$ 2009. Welfare Quality ${ }^{\circledR}$ assessment protocol for pigs (sow and piglets, growing and finishing pigs). Welfare Quality® Consortium, Lelystad, The Netherlands

Winckler C. \& Leeb C. 2010. Wachsende Betriebsgrößen und Tierschutz ein Widerspruch? Nutztierschutztagung Ramber-Grumpenstein: 11-14

Zheng D.M., Bonde M. \& Sørensen J.T. 2007. Associations between the proportion of Salmonella seropositive slaughter pigs and the presence of herd level risk factors for introduction and transmission of Salmonella in 34 Danish organic, outdoor (non-organic) and indoor finishing-pig farms. Livestock Science 106: 189-199 


\section{KAPITEL 4}

\section{Behavioural indicators of welfare in fattening pigs: Does}

herd size matter?

Prepared for submission

Applied Animal Behaviour Science 
Behavioural indicators of welfare in fattening pigs: Does herd size matter?

S. E. K. Meyer-Hamme ${ }^{1}$, C. Lambertz ${ }^{2}$, M. Gauly ${ }^{2}$

${ }^{1}$ Department of Animal Sciences, Georg-August-University, Albrecht-ThaerWeg 3, 37075 Göttingen, Germany

${ }^{2}$ Faculty of Science and Technology, Free University of Bozen-Bolzano, Universitätsplatz 5, 39100 Bolzano, Italy 


\section{Abstract}

Conventional production systems for fattening pigs that are characterized by large units are often criticized due to limitations for the animals to express their species-specific behaviour. Apart from the fact that there is no clear definition of intensive farming, scientifically-based knowledge on the effects of varying herd sizes on animal behaviour is still lacking. Therefore, the aim of this study was to assess the relationship between herd size and behavioural indicators. In total, 60 farms were evaluated using the various behavioural indicators of the Welfare Quality ${ }^{\circledR}$ protocol for pigs. Farms were classified according to their herd size into small ( $<1,500$ pigs/farm), medium $(1,500-3,000$ pigs/farm) and large ( $>$ 3,000 pigs/farm) farms with 20 farms in each class. Multiple Generalized Linear Mixed Models were used to evaluate differences between herd sizes. Data of the qualitative behaviour assessment were subjected to a Principle Component Analysis (PCA). Differences between the farm sizes were not found for the principle "appropriate behaviour", which aggregates all of the behavioural measures, and the criteria (social and other behaviour, positive emotional state and human-animal relationship) $(P>0.05)$. In tendency $(P<0.10)$, the panic response observed in $10 \%$ of the pens in large herds was lower than the 15 and $20 \%$ found in medium and small herds. The total active behaviour increased significantly with increasing farm size. Independent of the farm size, positive $(10 \%)$ was observed three times more often than negative social behaviour $(3 \%)$. However, determining factors that might influence social behaviour were not identified, mainly because the housing and management systems on the studied farms were similar. Among the different indicators that belong to the criterion "expression of other behaviours", pen investigation was observed at a rate of more than $20 \%$. The use of enrichment material, in contrast, was only performed for 2 to $4 \%$ of the total active behaviour. The proportion of investigation of the pen and exploration of enrichment material clearly indicates that under intensive fattening conditions the behavioural needs are not fulfilled. According to the PCA, none of the factors explained more than $39 \%$ of the total 
variance. Therefore, this method was not able to distinguish differences between the three farm sizes. In conclusion, findings of this preliminary study showed that none of the herd sizes proved to be clearly superior to others in terms of the expression of species-specific behaviour. Nevertheless, findings clearly indicate limitations of the current production systems.

Keywords: fattening pigs; herd size; behavioural indicators of the Welfare Quality $\circledR$ assessment protocol

\section{Introduction}

As one of the four principles in Welfare Quality ${ }^{\circledR}$ assessment protocol (Welfare Quality $\AA$, 2009) "appropriate behaviour" plays a major role and several measures were defined to assess it on-farm. In general, behavioural observations are useful to evaluate the expression of normal behaviour (Barnett \& Hemsworth, 1990). However, the affective state and positive emotions are difficult to assess and were highly neglected in previous studies (Ohl \& van der Staay, 2012). Recently, different approaches for the assessment of positive emotions have been tested (Meehan \& Mench, 2007; Dalmau et al., 2009). But, complex interactions still complicate interpretations (Boissy et al., 2007; Temple et al., 2011b). As a relatively new method, Qualitative Behaviour Assessment (QBA) integrates information from multiple behavioural signals and styles of behavioural expression directly in terms of their emotional expression (Wemelsfelder et al., 2000; Rutherford et al., 2012). According to Wemelsfelder \& Millard (2009), QBA is a valuable methodology for assessing animal behaviour under field conditions and is the most immediately practicable method for assessing positive emotions in animals (Rutherford et al., 2012). Consequently, QBA was integrated into the WQP as an animal-based measurement tool to assess "positive emotional state". Next to it, the social and exploratory behaviour and human-animal relationship were implemented to complement the behavioural assessment. With the help of human-animal 
relationship it is possible to detect the panic response of the pigs towards the farmer (Hemsworth et al., 1993).

Animals under intensive production are not anymore able to express their species-specific behaviour (Van de Weerd \& Day, 2009). This aspect has been criticised by politicians and many other stakeholders including farmers, consumers, media, animal-rights activists, veterinarians, and other actors from the industry. This criticism has intensified in recent years (Kayser et al., 2012; Velarde et al., 2015). Next to the conventional production systems for fattening pigs, which are characterized by fully slatted floors, forced ventilation and automatic feeding systems (Hoy et al., 2006) the increasing herd sizes (Turner et al., 2003; Windhorst \& Bräule, 2011; FAWC, 2012) were often criticised.

Apart from the fact that there is no clear definition of intensive or industrial farming, scientifically-based knowledge on the effects of varying herd sizes on the animal welfare status and especially animal behaviour is still lacking (Winckler \& Leeb, 2010). So far, studies mainly focused on the relationship between herd size and health parameters, like salmonellosis (Carstensen \& Christensen, 1998; Van der Wolf, 2001; Zheng et al., 2007; Baptista et al., 2010) or respiratory diseases (Maes et al., 2008; Grøntvedt et al., 2013). The results are contradictory. On the one hand, animals in larger units may be at a greater risk of pathogens imported into the farm with purchased animals and transmission of pathogens may be enhanced when a higher number of potentially susceptible animals is raised together (Gardner et al., 2002). On the other hand, larger farms usually are able to implement improved hygiene measures (Gardner et al., 2002). Studies exploring the effect of herd size on animal behaviour are rare, even though animal health and animal behaviour are closely linked. The occurrence of tail biting, an abnormal behaviour in pigs and one of the most common welfare problems in the pig industry (SchrøderPetersen \& Simonsen, 2001), did not differ between farm sizes (500 to 7,500 pigs/farm) (Moinard et al., 2003). Also, Knage-Rasmussen et al. (2013) did not find any relationship between the farm size (120 to 7,825 pigs/farm) and the performance of normal behaviour. Generally, comparisons are difficult due to 
widely variable study designs, country-specific production and environmental conditions and studied welfare indicators.

Recently, Temple et al. (2011a) found only minor differences of the welfare status through behavioural parameters in lberian pigs raised under intensive and extensive conditions between farms. No differences are seen in the expression of other behaviors, such as exploratory behavior and in humananimal relationship. They observed high occurrences of negative social behavior recorded in intensive conditions, which is clearly an indicator of poor welfare. But, effects of varying herd sizes on the animal behaviour and in particular positive emotions of fattening pigs were not assessed, yet. Therefore, the aim of this study was to assess the relationship between different herd sizes and behavioural indicators of welfare. In total, 60 conventional fattening pig farms, with herd sizes ranging from 250 to 11,000 pigs, were assessed using various behavioural indicators.

\section{Materials and methods}

\section{Farms and animals}

Data were recorded between September 2013 and June 2014 on 60 conventional pig fattening farms, located in Northern Germany. All farms were assessed by the same observer, who received intensive training on the correct application of the assessment according to the recommendation of the Welfare Quality $\AA^{\circledR}$ assessment protocol for growing pigs (WQP) beforehand.

A minimum herd size of 250 pigs was required and only conventional farms with common production systems (automatic feeding system, fully or partly-slatted floors, forced ventilation, all in-all out system) were included. The size of the farms ranged from 250 to 11,000 pigs. Farm size was defined as the number of pigs at one location, independent of whether the farmer raised pigs at other locations, too. Three farm size categories were defined: 1) small: $<1,500$ pigs/farm; 2) medium: 1,500 to 3,000 pigs/farm; and 3) large: > 3,000 pigs/farm. Twenty farms belonged to each of the categories. Eighty $\%$ of the farms only 
fattened pigs, while $20 \%$ had a closed system keeping sows, piglets and fattening pigs. All barns were insulated and had different mechanical ventilation systems. Two different feeding systems were implemented on the farms $(62 \%$ automatic or sensor-controlled liquid feeders; $38 \%$ pulp feeding automats). Pigs were kept on fully (92\% of the farms) or partly-slatted (8\%) concrete floors. More information about the farms and animals (genetic, sexes, management practice) can be looked up in detail in Meyer-Hamme et al. (2016).

\section{Behavioural assessment}

In this study, all measures that are used in the WQP to asses "appropriate behaviour" were used. "Appropriate behaviour" was assessed by means of the criteria social and other behaviour, positive emotional state and good humananimal relationship test. The criterion positive emotional state is measured with the help of qualitative behaviour assessment (QBA). The criterion expression of social behaviour is defined in terms of the measures of positive and negative social behaviour and the criterion exploratory behaviour is defined in terms of pen investigation and use of enrichment material. With the help of the panic response the criterion good human-animal-relationship was assessed.

\section{Qualitative Behaviour Assessment (QBA)}

The QBA is the animal-based measure for the evaluation of positive emotions. It is a behaviour observation method, where the observer looks at the animals without any restrictions. Not the original form of the QBA with a free choice profiling methodology was included in the Welfare Quality ${ }^{\circledR}$ protocol. In all farms, QBA was carried out for a total duration of $20 \mathrm{~min}$ at four viewpoints at each farm, which were randomly chosen. After $5 \mathrm{~min}$ at each observation point, the observer left the stable and recorded the observation. The behaviour of the pigs was described with a list of 20 fixed adjectives (Welfare Quality®, 2009): 1. active, 2. relaxed, 3. fearful, 4. agitated, 5. calm, 6. content, 7. tense, 8. enjoying, 9. frustrated, 10. bored, 11. playful, 12. positively occupied, 13. 
listless, 14. lively, 15. indifferent, 16. irritable, 17. aimless, 18. happy, 19. distressed and 20. sociable. A $125 \mathrm{~mm}$ visual analogue scale was assigned on which a line was drawn to signal whether that term was rather absent $(0 \mathrm{~mm}$, left side of the scale) or dominant (125 mm, right side of scale) in the previously observed pig groups. The values between 0 and 125 obtained on each farm for the 20 terms of the QBA are turned into an index due to a weighted sum. This index is then transformed into a score using I-spline function (Welfare Quality ${ }^{\circledR}$, 2009). QBA data were expressed at farm level.

\section{Expression of social and exploratory behaviour}

Following QBA, social and explanatory behaviour were assessed using the scan sampling method on three view points of the farm, which differed from the QBA points. First, all pigs in the pens had to stand up. If necessary, the hands were clapped before starting with the observation. Then, the pigs had $5 \mathrm{~min}$ time to calm down. Afterwards, 40-60 animals were scanned for a total time of 10 min at each observation point. A scan was made every 2 min. At first, pigs were scored as active or inactive (resting). Active behaviour was then further differentiated into positive social, negative social, pen investigation, use of enrichment material and other active behaviour. Negative social behaviour was defined as aggressive interaction, including any social behaviour with a response from the disturbed pig. Positive social behaviour is described as sniffing or nosing and moving gently away from the pig without an aggressive reaction. Investigation of the pen was defined as sniffing, nosing or licking all features of the pen, whereby use of enrichment material is described as play or exploring towards enrichment materials. Other active behaviour includes eating, drinking or air sniffing. The results of the behaviour observation were expressed as performed behaviour in percent of the total active behaviour. Thereby, positive and negative social behaviour were summarized to total social behaviour. 
Human-Animal Relationship

Ten randomly chosen pens were entered and the reaction of the animals towards the assessor was evaluated by a human-animal relationship test. After entering the pen and walking around it in one direction, the observer stood still in the middle of the pen for $30 \mathrm{sec}$. Subsequently, he walked around the pen in the other direction. Ratings were: 0 - no panic present and 2 - more than $60 \%$ of the pigs showed panic behaviour (e.g. fleeing). For the human-animal relationship test, the amount of pens with a panic response from the total observed pens per farm expressed in percent was used for further analysis.

\section{Statistical analyses}

The SAS statistical package version 9.3 (SAS Institute Inc., 2010) was used to analyse the data. Farm was defined as the statistical unit. A log- or an arcsintransformation was done before further analysis. Results were considered statistically significant at $P<0.05$. Multiple Generalized Linear Mixed Models were performed separately for the scores calculated for the principle "appropriate behaviour", the associated criteria and behavioural measures (the 20 adjectives of the QBA, the results of the behaviour observation and of the human-animal relationship test) using the GLIMMIX procedure. The statistical model included the farm size (small, medium and large) as a fixed and the farm as random effect.

Data of QBA were, in addition, analysed with a Principle Component Analysis applying the PROC FACTOR procedure. The constitutional theory of this method is that there are underlying principles in the adjectives which influence each other (O'Rourke \& Hatcher, 2013). For example, an animal cannot be content without being happy and there might be an influence between active and playful. Single PCAs were calculated for each farm size category.

The first two Principle Components (Factor 1 and Factor 2) identified with an Eigenvector of greater than 1.0 were applied. They explained at least $23.6 \%$ up to $31.4 \%$ of the total variance in the different PCAs. Each adjective achieved a 
certain factor loading on Factor 1 and Factor 2, which is a dimensionless number between -1 and 1 . The factor loadings quantified the weight each adjective had on the two main axes (Rencher, 2002). Factor loadings greater than or equal to 0.40 were interpreted as highly positive and factor loadings less than or equal to -0.40 as highly negative (O'Rourke \& Hatcher, 2013). The values obtained were plotted in two dimensional interpretative word charts, which were used to lead the interpretations of the first two Factors.

Finally, Spearman Rank Correlation Coefficients (RS) between factor loadings on Factor 1 and Factor 2 of different farm size categories were calculated for each main Factor by the PROC CORR procedure. A correlation coefficient equal to or greater than 0.4 was interpreted as a moderate correlation whereby a coefficient equal to or greater than 0.7 as a strong correlation.

\section{Results}

\section{Qualitative Behaviour Assessment (QBA)}

The mean length of the scale scored by QBA is shown in Table 1. Generally, high standard deviations of descriptors were found, except for "distressed", "indifferent" and "aimless". For none of the 20 tested adjectives of the QBA a difference was found between the three farm size categories $(P>0.05)$. 
Table 1: Qualitative behaviour assessment of the Welfare Quality $®$ assessment protocol for growing pigs expressed in $\mathrm{mm}$ and the standard division of the scale $(0-125 \mathrm{~mm}$ ) separated by farm size (small: $<1,500$ pigs/farm, medium: 1,500 to 3,000 pigs/farm and large: $>3,000$ pigs/farm)

\begin{tabular}{|c|c|c|c|c|c|c|}
\hline & \multicolumn{6}{|c|}{ Farm size } \\
\hline & \multicolumn{2}{|c|}{ Small } & \multicolumn{2}{|c|}{ Medium } & \multicolumn{2}{|c|}{ Large } \\
\hline & LSMeans & SE & LSMeans & SE & LSMeans & SE \\
\hline Active & 52.75 & 24.38 & 61.70 & 21.54 & 54.40 & 19.35 \\
\hline Relaxed & 38.60 & 25.33 & 27.60 & 17.18 & 31.60 & 21.75 \\
\hline Fearful & 24.55 & 14.83 & 25.90 & 24.32 & 17.30 & 17.09 \\
\hline Agitated & 37.45 & 23.24 & 49.85 & 22.44 & 40.70 & 21.01 \\
\hline Calm & 37.45 & 19.21 & 24.65 & 9.94 & 32.35 & 19.71 \\
\hline Content & 40.50 & 11.11 & 40.75 & 9.81 & 42.05 & 12.09 \\
\hline Tense & 24.95 & 16.14 & 30.60 & 23.72 & 33.25 & 20.80 \\
\hline Enjoying & 42.20 & 13.68 & 43.30 & 11.68 & 42.00 & 12.88 \\
\hline Frustrated & 9.60 & 9.77 & 13.15 & 12.86 & 10.50 & 13.31 \\
\hline Sociable & 42.70 & 18.94 & 44.30 & 14.41 & 42.25 & 18.15 \\
\hline Bored & 24.80 & 19.04 & 13.75 & 12.35 & 12.55 & 14.46 \\
\hline Playful & 37.60 & 18.25 & 42.20 & 15.40 & 39.20 & 13.61 \\
\hline Positively occupied & 42.90 & 13.66 & 42.15 & 9.25 & 44.00 & 12.44 \\
\hline Listless & 18.00 & 16.08 & 9.05 & 11.08 & 12.20 & 16.63 \\
\hline Lively & 47.60 & 22.38 & 50.85 & 18.81 & 48.75 & 19.71 \\
\hline Indifferent & 9.85 & 7.49 & 7.55 & 5.76 & 6.40 & 6.34 \\
\hline Irritable & 31.20 & 20.95 & 36.50 & 21.01 & 31.00 & 21.47 \\
\hline Aimless & 10.20 & 11.50 & 4.00 & 1.49 & 7.10 & 6.50 \\
\hline Happy & 35.45 & 10.01 & 39.10 & 11.29 & 39.35 & 11.60 \\
\hline Distressed & 2.90 & 1.07 & 3.25 & 1.48 & 2.75 & 0.97 \\
\hline
\end{tabular}


Figure 1 visualises the factor loadings of each QBA adjective on Factor 1 and Factor 2 separated by farm size. Exemplarily, a comparison between farm size categories is displayed for the three selected adjectives agitated (ag), listless (li) and bored (bo).

For the small farm size, Factor 1 retained $39.4 \%$ and Factor 2 another $21.0 \%$ of the total variance. In the PCA of the medium farm size, Factor 1 explained $35.3 \%$ and Factor 2 another $22.8 \%$ of the total variance. For large farms, Factor 1 explained $32.4 \%$ and Factor 2 another $23.9 \%$ of the total variance.

Visible from Figure 1, certain adjectives vary largely between the three farm size categories (content, happy, aimless). Factor 1 of the small and large herd sizes had highly positive values for adjectives describing active behaviour with a positive connotation (active, agitated, enjoying, playful, lively, sociable) and highly negative values for adjectives describing inactivity (bored, calm, relaxed). Factor 1 of the medium herd size, on the other hand, showed adjectives expressing negative behaviour (fearful, agitated, tense, frustrated and irritable) with highly positive loadings and descriptive terms in the sense of positive inactivity (relaxed, calm, content, enjoying, happy) with highly negative loadings. This non-conformity is also found in the examination of Factor 2. This is described with highly positive loadings for terms suggesting frustration (irritable, aimless and listless) and with highly negative loadings for terms of relaxation (relaxed, calm, happy and positively occupied) for small and large farm sizes. However, in terms of the Factor 2 of the medium farms, highly positive loadings for adjectives describing activity (active, lively) and highly negative loadings for those describing negatively connoted behaviour (bored, listless, indifferent). 


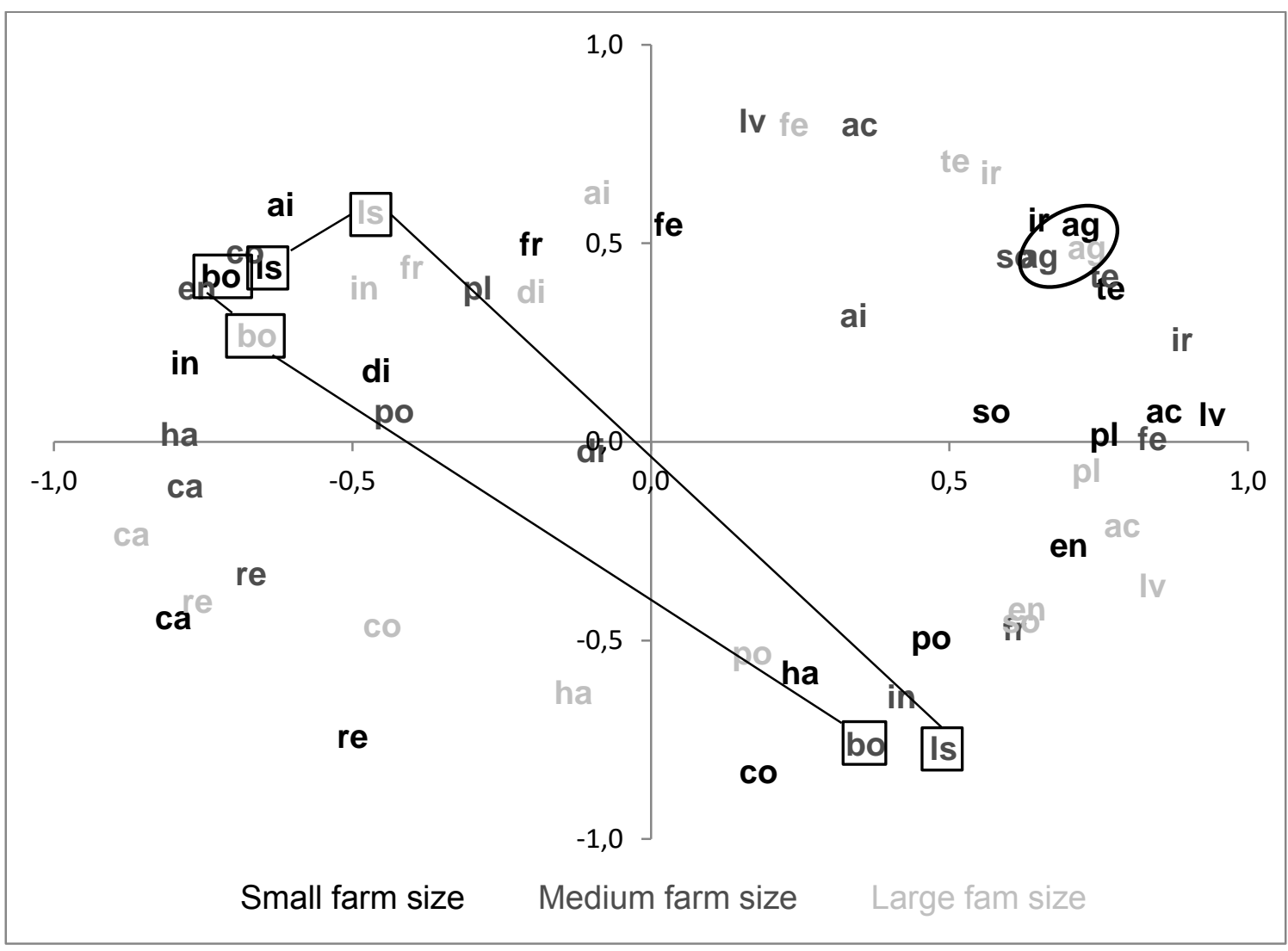

Figure 1: Word chart presenting loadings on factor 1 and 2 of the Principal Component Analysis for the twenty different adjectives scores for small (black), medium (dark grey) and large (light grey) farms (ac = active, re = relaxed, fe = fearful, ag = agitated, $\mathrm{ca}=$ calm, $\mathrm{co}=$ content, te $=$ tense, en = enjoying, $\mathrm{fr}=$ frustrated, so $=$ sociable, bo $=$ bored, $\mathrm{pl}=$ playful, $\mathrm{po}=$ positively occupied, $\mathrm{Is}=$ listless, Iv = lively, in = indifferent, ir = irritable, ai = aimless, ha = happy, di = distressed)

A good agreement, expressed as short distances of the same adjective between farm sizes was found for the adjectives agitated (ag), tense (te), calm (ca), irritable (ir) and relaxed (re) (Figure 1). There is still an equal distribution of adjectives like sociable (so), content (co) and aimless (ai) in the word chart. For the adjectives listless (li), bored (bo), interesting (in), enjoying (en) and frustrated ( $\mathrm{fr}$ ) distances were large between medium farms and the two other farm sizes, which were close to each other. 
In Table 2, the Spearman Rank Correlation Coefficients (RS) for Factor 1 and Factor 2 are presented. The RS for Factor 1 (0.91) and 2 (0.86) indicate a strong and significant correlation between the small and large farm. Factor 1 and Factor 2 were less consistent between small and medium as well as between medium and large farms.

Table 2: Spearman Rank Correlation Coefficients for Principle Component 1 (Factor 1 ) and 2 (Factor 2 ) between the three different farm size categories

\begin{tabular}{llll}
\hline & Comparison & \multicolumn{2}{l}{ Spearman Rank Correlation Coefficient } \\
& & Factor 1 & Factor 2 \\
\hline Farm size & Small to medium & 0.10 & -0.11 \\
& Small to large & $0.91^{*}$ & $0.86^{*}$ \\
& Medium to large & 0.32 & -0.29 \\
\hline
\end{tabular}

${ }^{\star} P<0.05$.

\section{Expression of social and other behaviour}

The total active behaviour increased, in tendency, with increasing farm size according the F-Test $(P=0.0545)$. After adjusting for multiple comparisons there was a significant difference between small and large farms $(P<0.05)$. Independent of the farm size, positive (10\%) was observed three times as often as negative social behaviour (3\%). Among the different indicators that belong to the criterion "expression of other behaviours", pen investigation was observed most often at a rate of more than $20 \%$. The use of enrichment material, in contrast, was only performed for 2 to $4 \%$ of the total active behaviour. 
Table 3: Effect of farm size (small: < 1,500 pigs/farm, medium: 1,500 to 3,000 pigs/farm and large: > 3,000 pigs/farm) on the variables of the social and exploratory behaviour (LSMeans \pm SE)

\begin{tabular}{|c|c|c|c|c|c|c|}
\hline \multirow[t]{2}{*}{ Behavioural measure } & \multirow[b]{2}{*}{ Small } & \multicolumn{2}{|l|}{ Farm size } & \multirow[t]{2}{*}{ Minimum } & \multirow[t]{2}{*}{ Maximum } & \multirow[t]{2}{*}{$P$ value } \\
\hline & & Medium & Large & & & \\
\hline Active & $56.57^{a} \pm 2.33$ & $58.60^{\mathrm{ab}} \pm 2.26$ & $64.61^{b} \pm 2.52$ & 36.25 & 83.66 & 0.0545 \\
\hline Negative social & $3.12 \pm 0.43$ & $3.25 \pm 0.41$ & $2.63 \pm 0.46$ & 0.41 & 8.92 & 0.5424 \\
\hline Positive social & $9.41 \pm 0.71$ & $10.05 \pm 0.69$ & $10.87 \pm 0.77$ & 3.56 & 18.79 & 0.6113 \\
\hline Exploration of pen & $22.48 \pm 1.70$ & $22.45 \pm 1.65$ & $24.71 \pm 1.84$ & 11.44 & 39.14 & 0.5978 \\
\hline Exploration of enrichment material & $2.58 \pm 0.56$ & $4.27 \pm 0.55$ & $3.16 \pm 0.61$ & 0.00 & 9.88 & 0.0973 \\
\hline
\end{tabular}

$\overline{a, b}$ Different letters within rows indicate significant differences $(P<0.05)$. 


\section{Human-Animal Relationship}

In tendency $(P<0.10)$, the panic response observed in $10 \%$ of the pens in large herds was lower than the 15 and $20 \%$ found in medium and small herds. In small farms, the maximum prevalence of groups with a panic response reached $70 \%$ of the observed pens, while in medium and large farms at most $40 \%$ of the pens showed this response.

\section{Discussion}

In general, behaviour is an important component of animal welfare as it reflects the animal's feeling. Therefore, it is of utmost importance to include both psychological and physiological parameters for its assessment (Duncan \& Petherick, 1991). The evaluation of behaviour has become of sustainable interest in the last years, whereby the emotional state is difficult to assess (Boissy et al., 2007). Independent of the herd size, farms in this study reached only 32 of 100 points for this principle, which has to be considered as low. Generally, intensive systems are often criticised with respect to species-specific behaviour (Van de Weerd \& Day, 2009). Comparable studies on fattening pigs using measures of the WQP to evaluate pigs' behaviour are not widely available, yet. Studying only three intensive fattening pig farms, Otten et al. (2013) found values for "appropriate behaviour" for each farm slightly better (approximately 45 points) than in our study. The present findings also coincide with results of Knage-Rasmussen et al. (2013), who did not find any relationship between the number of pigs per farm (120 to 7,825 pigs/farm) and behavioural measurements such as aggression, exploration and fear of humans.

\section{Qualitative behaviour assessment}

Several studies clearly identify QBA as one of the most appropriate methods for the assessment of emotions in animals (Rutherford et al., 2012; Phythiana et al., 2013). First of all, there was no significant difference between the three farm 
size categories when comparing the millimetre lengths assigned to each adjective in the QBA. In literature, however, millimetre scores are not often compared, although it was also carried out in some studies (Temple et al., 2011a; Otten et al., 2013). Comparable to the present study, only a low proportion of pigs showed behavioural patterns such as frustrated, indifferent and distressed (Otten et al., 2013). Regarding behavioural patterns that are negatively connoted (tense, agitated, irritable), previous findings indicated a high level of disturbance present in the animals (Temple et al., 2011a).

For further interpretation of the QBA results the Principle Component Analysis (PCA) was proposed (Temple et al., 2011b). There might be some agreement which is not taken into account when analysing the adjectives separately warranting the use of PCA (Wemelsfelder \& Millard, 2009; Phythiana et al., 2013). The PCA showed a high variation for most of the adjectives included in the QBA between medium and both other herd size classes in terms of the factor loadings. The differences between herd sizes were secured by the Spearman Rank correlation coefficients.

In the study of Wemelsfelder \& Millard (2009), Factor 1 distinguished between positive and negative mood and Factor 2 differentiated this mood in low and high levels of arousal. In the present study, Factor 1 of the small and large herd sizes have highly positive values in adjectives describing active behaviour with a positive connotation. Factor 1 of the medium herd sizes has adjectives expressing negative behaviour. The contrasting findings of the QBA are complicated to interpret due to the complex physiological system involved with emotions (Temple et al., 2011b).

Differences found between medium and the other two herd size classes can, in general, not be explained by differences between the 60 farms regarding their husbandry system or management procedures. However, there might be unknown and unpredictable time effects (e.g. disease outbreak or extreme weather events). In order to minimize errors related to the assessment procedures, all farms were assessed by the same observer after intensive training on the use of the adjectives. Nevertheless, there might be influences on 
the outcomes due to the mood of the observer (Temple et al., 2013). The observer might transfer his own feelings and expectations to the animals, which is often the problem when subjective behavioural observations are conducted (Tuyttens et al., 2014). But Temple et al. (2011b) also noticed, that the QBA appears to be useful to differentiate and is sufficiently robust to distinguish between intensive farms. However, it was not possible to identify factors that could explain the differences between the PCAs of the medium and the other two herd size classes.

It has to be mentioned, that none of the factors explained more than $39 \%$ of the total variance in the different PCAs. In general, the interpretation of the QBA may gain in stability when applied to farms with a higher variation of production systems then in this study, while more than one visit seems to be necessary when a comparably low variation exists (Temple et al., 2013).

\section{Expression of social and exploratory behaviour}

In general, the scan sampling method allows a short time of observation. It is a good techniques for measuring states (Mann, 1999) and is accurate and precise for measuring durations of standing, lying, and feeding behaviours but were less precise for drinking and walking behaviors (Mitlöhner et al., 2001). Brief events can also be missed and the method can be problematic, when sporadic behaviour occurs.

The results for the social behaviour observed in the present study were similar to findings of Temple et al. (2011a), who reported values of $12.2 \%$ for positive and $5.4 \%$ for negative social behaviour. These similar values highlight the reliability of the scan sampling methodology.

Negative social behaviour is a clear indicator of insufficient welfare, because it correlates with a high number of stressful situations and competition for resources like feeding places. It has to be noted that differences between herd sizes were not significant. Other authors (Temple et al., 2011a) found significant variability among conventional farms for positive and negative social behaviours 
and explained the variation as a result of the interaction of several factors. The most important factors that have been reported in the literature are management-related factors (mixing of animals and growing stage (Courboulay et al., 2009), castration status (Fredriksen et al., 2008), genetics (Breuer et al., 2003) or housing systems like limited available space, limited resource, mixing of animals (Ewbank \& Bryant, 1972). Again, variation between the studied farms of this study was low, so that none of these factors could be related to the expression of social behaviour. Furthermore the overall occurrence of negative social behaviour was quit low. If more than $7 \%$ of the animals on a farm are observed with this behaviour, it should be considered as having a welfare problem with regard to social negative behaviour (Temple et al., 2011a). In the present study for two of the 60 farms this threshold was exceeded $(8 \%$ and $9 \%)$.

The proportion of investigation of the pen and exploration of enrichment material in our as well as previous studies (Temple et al., 2011b) clearly indicates that under intensive fattening conditions the behavioural needs are not fulfilled. This becomes obvious with regard to extensive housing conditions where exploratory behaviour is performed at much higher rates $(40 \%)$ (Temple et al., 2011b). Although all of the observed pens in the present study were provided with toys, the occurrence of exploration of enrichment material was low (around 3\%). An explanation might be caused by the fact that the provided material is not sufficiently interesting for stimulation the pigs to manipulate them. An attractive and appropriate enrichment material should frequently be renewed and never be spoiled with manure (Studnitz et al., 2007).

Positive social behaviour was observed at higher frequencies than negative social behaviour, again without any difference between herd sizes. Positive social behaviour reduces the negative effects of stressful events, and hence, is related to good welfare (Temple et al., 2011b). However, a social interaction may begin as a positive one (i.e. licking) and end up in a negative (i.e. biting). Therefore, high levels of positive social activity may not necessarily reflect a positive mood of the animal (Boissy et al., 2007). In consequence, the 
interpretation of high frequencies of positive social behaviour should be interpreted carefully (Temple et al., 2011b). Active behaviour was significantly more often observed in larger herd sizes. The increase of active behaviour is probably due to a higher level of other active behaviour like eating, drinking, sitting or watching the surroundings, so that the whole active behaviour increases with increasing herd size. However, ranges of active behaviour were wide, thus indicating that some farms differed from the others regarding active behaviour. A high variability of active behaviour between farms was also observed by Temple et al. (2011a).

\section{Human-animal relationship}

The human-animal relationship is largely affected by the way farmers interact with their animals (Hemsworth et al., 1993). With the help of this parameter it is possible to detect the fear response of the pigs toward the stockman, which is a major welfare problem and alters not only the well-being, but also the productivity, product quality and profitability of farm animals (Waiblinger et al., 2006). On average, a panic response was observed in $14 \%$ of the farms, which was in tendency higher in small farms $(20 \%)$. When a small farm was recorded with a panic response up to $70 \%$ of the single pens were affected, while for medium to large farms at most $40 \%$ of the pens showed this behaviour. According to Temple et al. (2011b), a maximum of $30 \%$ of the pens showing a panic response can be considered as having a good welfare status in terms of the relationship between animal and farmer. Apart from an adequate interaction, there are other important factors influencing the human-animal relationship such as genetics, growing stage, rearing system (Waiblinger et al., 2006), feed supply (Hemsworth et al., 1993) or group size (Meyer-Hamme et al., 2015). However, it was not possible to associate any of these factors with the humananimal-relationship because of the limited number of studied farms and a limited variation. 


\section{Conclusion}

In conclusion, findings of this preliminary study showed that none of the herd sizes proved to be clearly superior to others in terms of species-specific behaviour. Nevertheless, findings clearly indicate limitations of the current production systems. Further studies are warranted to study the effects of other factors like the management (e.g. care of animals, health management, expertise of the stockman), feedings system or the floor type in combination with the farm size on the species-specific behaviour of fattening pigs.

\section{Acknowledgements}

The study was supported by the PhD-Program "Animal Welfare in Intensive Livestock Production Systems" funded by Lower Saxony, Germany. The authors are grateful to Dr. Karl-Heinz Tölle, Dr. Conrad Welp, Dr. Jörg Bauer, Martin Knees, Georg Freisfeld, Gert Stelling and all the farmers for their cordial collaboration.

\section{References}

Baptista F.M., Alban L., Nielsen L.R., Domingos I., Pomba C. \& Almeida V. 2010. Use of herd information for predicting salmonella status in pig herds. Zoonoses and Public Health 57: 49-59

Barnett J.L. \& Hemsworth P.H. 1990. The validity of physiological and behavioural measures of animal welfare. Applied Animal Behaviour Science 25: 177-187

Boissy A., Manteuffel G., Jensen M.B., Moe R.O., Spruijt B., Keeling L.J., Winckler C., Forkman B., Dimitrov I., Langbein J., Bakken M., Veissier I. \& Aubert A. 2007. Assessment of positive emotions in animals to improve their welfare. Physiology and Behavior 22: 375-397 
Breuer K., Sutcliffe M.E.M., Mercer J.T., Rance K.A., Beattie V.E., Sneddon I.A. \& Edwards S.A. 2003. The effect of breed on the development of adverse social behaviours in pigs. Applied Animal Behaviour Science 84: 59-74

Carstensen B. \& Christensen J. 1998. Herd size and sero-prevalence of Salmonella enterica in Danish swine herds: a random-effects model for register data. Preventive Veterinary Medicine 34: 191-203

Courboulay V., Eugène A. \& Delarue E. 2009. Welfare assessment in 82 pig farms: effect of animal age and floor type on behaviour and injuries in fattening pigs. Animal Welfare 18: 515-521

Dalmau A., Fabrega E. \& Velarde A. 2009. Fear assessment in pigs exposed to a novel object test. Applied Animal Behaviour Science 117: 173-180

Duncan I.J. \& Petherick J. 1991. The implications of cognitive processes for animal welfare. Journal of Animal Science 69: 5017-5022

Ewbank R. \& Bryant M.J. 1972. Aggressive behaviour amongst groups of domesticated pigs kept at various stocking rates. Animal Behaviour 20: $21-28$

FAWC 2012. Report on Farm animal welfare: Health and disease. Farm Animal Welfare Committee, Department for Environment, Food and Rural Affairs, London, United Kingdom: 1-72

Fredriksen B., Lium B.M., Marka C.H., Mosveen B. \& Nafstad O. 2008. Entire male pigs in farrow-to-finish pens: Effects on animal welfare. Applied Animal Behaviour Science 110: 258-268

Gardner I.A., Willeberg P. \& Mousing J. 2002. Empirical and theoretical evidence for herd size as a risk factor for swine diseases. Animal Health Research Reviews 3: 43-55 
Grøntvedt C.A., Er C., Gjerset B., Hauge A.G., Brun E., Jørgensen A., Lium B. \& Framstad T. 2013. Influenza $A(H 1 N 1) p d m 09$ virus infection in Norwegian swine herds 2009/10: The risk of human to swine transmission. Preventive Veterinary Medicine 110: 429-434

Hemsworth P.H., Barnett J.L. \& Coleman G.J. 1993. The human-animal relationship in agriculture and its consequences for the animal. Animal Welfare 2: 33-51

Hoy S., Gauly M. \& Krieter J. 2006. Nutztierhaltung und -hygiene, Grundwissen Bachelor. Ulmer Eugen Verlag, Stuttgart, Germany, 125-133

Kayser M., Schlieker K. \& Spiller A. 2012. Die Wahrnehmung des Begriffs "Massentierhaltung" aus Sicht der Gesellschaft. Berichte über Landwirtschaft 90: 417-427

Knage-Rasmussen K.M., Sørensen J.T., Rousing T. \& Houe H. 2013. No association between sow and slaughter pig herd size and animal welfare index based on on-farm welfare assessment. "Does big mean bad? The science behind large scale production". Roslin Institut, University Edinburgh United Kingdom.

Maes D., Segales J., Meyns T., Sibila M., Pieters M. \& Haesebrouck F. 2008. Control of Mycoplasma hyopneumoniae infections in pigs. Veterinary Microbiology 126: 297-309

Mann J. 1999. Behavioural sampling methods for cetaceans: A review and critique. Marine Mammal Science 15: 102-122

Meehan C.L. \& Mench J.A. 2007. The challenge of challenge: Can problem solving opportunities enhance animal welfare? Applied Animal Behaviour Science 102: 246-261 
Meyer-Hamme S.E., Lambertz C. \& Gauly M. 2016. Does group size have an impact on welfare indicators in fattening pigs? Animal 10: 142-149

Mitlöhner F.M., Morrow-Tesch J.L., Wilson S.C., Dailey J.W. \& McGlone J.J. 2001. Behavioral sampling techniques for feedlot cattle. Journal of Animal Science 79: 1189-1193

Moinard C., Mendl M., Nicol C.J. \& Green L.E. 2003. A case control study of onfarm risk factors for tail biting in pigs. Applied Animal Behaviour Science 81: $333-355$

O'Rourke N. \& Hatcher L. 2013. Factor Analysis and Structural Equation Modeling. SAS $\otimes$ Institute Inc. Cary, North Carolina, USA.

Ohl F. \& van der Staay F.J. 2012. Animal welfare: At the interface between science and society. The Veterinary Journal 192: 13-19

Otten D., Annas E. \& Van den Weghe H.F.A. 2013. The application of animal welfare standards in intensive production systems using the assessment

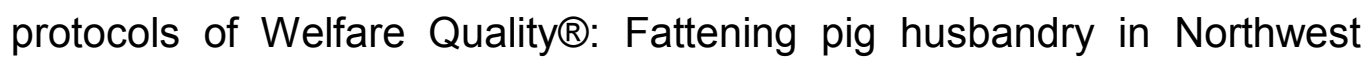
Germany. International Journal of Livestock Production 4: 49-59

Phythiana C., Michalopoulou E., Duncana J. \& Wemelsfelder F. 2013. Interobserver reliability of Qualitative Behavioural Assessments of sheep. Applied Animal Behaviour Science 144: 73-79

Rencher A.C. 2002. Principal component analysis. Rencher A. C.: Methods of Multivariate Analysis, John Wiley and sons, New York

Rutherford K.M.D., Donald R.D., Lawrence A.B. \& Wemelsfelder F.o. 2012. Qualitative Behavioural Assessment of emotionality in pigs. Applied Animal Behaviour Science 139: 218-224

Schrøder-Petersen D.L. \& Simonsen H.B. 2001. Tail biting in pigs. The Veterinary Journal 162: 196-210 
Studnitz M., Jensen M.B. \& Pedersen L.J. 2007. Why do pigs root and in what will they root?: A review on the exploratory behaviour of pigs in relation to environmental enrichment. Applied Animal Behaviour Science 107: 183197

Temple D., Dalmau A., Ruiz de la Torre J., Manteca X. \& Velarde A. 2011a. Application of the Welfare Quality $®$ protocol to assess growing pigs kept under intensive conditions in Spain. Journal of Veterinary Behaviour: Clinical Applications and Research 6: 138-149

Temple D., Manteca X., Velarde A. \& Dalmau A. 2011b. Assessment of animal welfare through behavioural parameters in lberian pigs in intensive and extensive conditions. Applied Animal Behaviour Science 131: 29-39

Temple D., Manteca X., Dalmau A. \& Velarde A. 2013. Assessment of testretest reliability of animal-based measures on growing pig farms. Livestock Science 151: 35-45

Turner S.P., Allcroft D.J. \& Edwards S.A. 2003. Housing pigs in large social groups: a review of implications for performance and other economic traits. Livestock Production Science 82: 39-51

Tuyttens F.A.M., de Graaf S., Heerkens J.L.T., Jacobs L., Nalon E., Ott S., Stadig L., Van Laer E. \& Ampe B. 2014. Observer bias in animal behaviour research: can we believe what we score, if we score what we believe? Animal Behaviour 90: 273-280

Van de Weerd H.A. \& Day J.E.L. 2009. A review of environmental enrichment for pigs housed in intensive housing systems. Applied Animal Behaviour Science 116: 1-20

Van der Wolf P.J. 2001. Herd level husbandry factors associated with the serological Salmonella prevalence in finishing pig herds in The Netherlands. Veterinary Microbiology 78: 205-219 
Velarde A., Fabrega E., Blanco-Penedo I. \& Dalmau A. 2015. Animal welfare towards sustainability in pork meat production. Meat Science 109: 13-17

Waiblinger S., Boivin X., Pedersen V., Tosi M.-V., Janczak A.M., Visser E.K. \& Jones R.B. 2006. Assessing the human-animal relationship in farmed species: A critical review. Applied Animal Behaviour Science 101: 185242

Welfare Quality ${ }^{\circledR}$ 2009. Welfare Quality ${ }^{\circledR}$ assessment protocol for pigs (sow and piglets, growing and finishing pigs). Welfare Quality ${ }^{\circledR}$ Consortium, Lelystad, The Netherlands

Wemelsfelder F., Hunter E.A., Mendl M.T. \& Lawrence A.B. 2000. The spontaneous qualitative assessment of behavioural expressions in pigs: first explorations of a novel methodology for integrative animal welfare measurement. Applied Animal Behaviour Science 67: 193-215

Wemelsfelder F. \& Millard F. 2009. Qualitative Behavioural Assessment. In Assessment of animal welfare measures for sows, piglets and fattening pigs. Welfare Quality Report No. 10, 213-219

Winckler C. \& Leeb C. 2010. Wachsende Betriebsgrößen und Tierschutz ein Widerspruch? Nutztierschutztagung Ramber-Grumpenstein: 11-14

Windhorst H.-W. \& Bräule H. 2011. Analyse zu Strukturen und Entwicklungen in der Schweine- und Sauenhaltung in Deutschland. Universität Vechta, Mitteilungen 77: 10-22

Zheng D.M., Bonde M. \& Sørensen J.T. 2007. Associations between the proportion of Salmonella seropositive slaughter pigs and the presence of herd level risk factors for introduction and transmission of Salmonella in 34 Danish organic, outdoor (non-organic) and indoor finishing-pig farms. Livestock Science 106: 189-199 


\title{
KAPITEL 5
}

Does group size have an impact on welfare indicators in fattening pigs?

\author{
Animal \\ 10 (2016) 142-149 \\ (C) The Animal Consortium 2016 \\ DOI: $10.1017 / S 1751731115001779$
}


Does group size have an impact on welfare indicators in fattening pigs?

S. E. K. Meyer-Hamme ${ }^{1}$, C. Lambertz ${ }^{2}$, M. Gauly ${ }^{2}$

${ }^{1}$ Department of Animal Sciences, Georg-August-University, Albrecht-ThaerWeg 3, 37075 Göttingen, Germany

${ }^{2}$ Faculty of Science and Technology, Free University of Bozen-Bolzano, Universitätsplatz 5, 39100 Bolzano, Italy

Short title: Effect of group size on welfare in fattening pigs 


\section{Abstract}

Production systems for fattening pigs have been characterized over the last two decades by rising farm sizes coupled with increasing group sizes. These developments resulted in a serious public discussion regarding animal welfare and health in these intensive production systems. Even though large farm and group sizes came under severe criticism, it is still unknown whether these factors indeed negatively affect animal welfare. Therefore, the aim of this study was to assess the effect of group size (< 15 vs. 15 to 30 vs. > 30 pigs/pen) on various animal-based measures of the Welfare Quality ${ }^{\circledR}$ protocol for growing pigs under conventional fattening conditions. A total of 60 conventional pig fattening farms with different group-sizes in Germany were included. Moderate bursitis (35\%) was found as the most prevalent indicator of welfare-related problems, while its prevalence increased with age during the fattening period. However, differences between group sizes were not detected $(P>0.05)$. The prevalence of moderately soiled bodies increased from $9.7 \%$ at the start to $14.2 \%$ at the end of the fattening period, whereas large pens showed a higher prevalence $(15.8 \%)$ than small pens $(10.4 \%$; $P<0.05)$. With increasing group size, the incidence of moderate wounds with 8.5 and $11.3 \%$ in small- and medium-sized pens, respectively, was lower $(P<0.05)$ than in large-sized ones $(16.3 \%)$. Contrary to bursitis and dirtiness, its prevalence decreased during the fattening period. Moderate manure was less often found in pigs fed by a dry feeder than in those fed by a liquid feeding system $(P<0.05)$. The humananimal relationship was improved in large in comparison to small groups. On the contrary, negative social behaviour was found more often in large groups. Additionally, with increasing live weight, the prevalence of exploration of enrichment material decreased. Given that all animals were tail-docked, tail biting was observed at a very low rate of $1.9 \%$. In conclusion, the results indicate that body weight and feeding system are determining factors for the welfare status, while group size was not proved to affect the welfare level under the studied conditions of pig fattening. 
Keywords: animal-based measures; fattening pigs; group size; welfare indicators

\section{Implications}

Production systems for fattening pigs have been characterized over the last two decades by rising farm sizes coupled with increasing group sizes, in order to optimize management and efficiency. Concerns about animal welfare in these systems are under intensive discussion. Lack of scientifically-proven studies contributes to the negative image of modern livestock farming. Therefore, the welfare level of 60 fattening pig farms in Germany was assessed and the effect of group size on welfare indicators was evaluated to identify an optimal group size proved to be superior to others in terms of animal welfare. This will be an important contribution for the future discussion as group size is one of the most criticized aspects among the welfare debate.

\section{Introduction}

During the last decades, the pig fattening industry has shifted towards larger farm sizes mainly due to limited profits (FAWC, 2012). At the same time, some farmers changed the housing system from small groups of 12-15 pigs to large (> 50 pigs) (Turner \& Edwards, 2004) and even mega groups (> 100 pigs) (Samarakone \& Gonyou, 2008) in order to optimize management and labour efficiency (Schmolke et al., 2003). Common group sizes for growing pigs in Germany range between 10 and 30 animals, even though groups of 40 to 100 or even more animals were proposed by a few farms as a management strategy to improve overall profitability (Schmolke et al., 2003). In Germany, pigs under conventional production conditions, are generally fattened indoors and barns are generally characterized by fully slatted floors, forced ventilation and automatic feeding systems (Hoy et al., 2006). Recently, these production systems, particularly under conditions of large farms and group sizes, have been under serious discussion mainly due to animal welfare concerns (Schröder \& McEachern, 2004; Kayser et al., 2012; Velarde et al., 2015). 
Studies using various welfare-related measures indicate negative impacts when groups sizes exceed those found in the wild, which are usually comprised of two to four sows with their most recent litters and juvenile offspring of previous litters (Gonyou, 2001). McGlone \& Newby (1994) found that injury and morbidity rates were greater for pigs in groups of 40 than of 10 or 20 animals. In contrast, Samarakone \& Gonyou (2008) did not find differences for mortality, morbidity or behavioural vices, such as tail biting, when comparing groups of around 20 and 100 pigs. The meta-analysis of Averós et al. (2010) did also not provide any evidence that group size affects the lying behaviour.

Because the welfare status of animals is multi-factorial, a combination of various parameters is necessary for its evaluation. The Welfare Quality ${ }^{\circledR}$ assessment protocol (WQP) for growing pigs (Welfare Quality $®$, 2009) is an adequate tool to address the effects of group size on farm. As a multidimensional concept, it integrates the absence of thirst, hunger, discomfort, disease, pain and injuries, stress and the expression of normal behaviour. Recent studies on the welfare status of growing pigs raised under intensive conditions reported only minor differences between farms (Temple et al., 2011a; Temple et al., 2012). However, group size effects on the animal-based indicators of the protocol were not assessed, yet. Therefore, the aim of this study was to compare different group sizes under conventional fattening conditions in terms of welfare-related indicators of the WQP.

\section{Material and methods}

Farm selection and housing system

A total of 60 conventional pig fattening farms with herd sizes between 250 and 11,000 pigs, located in Northern Germany, were assessed. The assessments were conducted between September 2013 and June 2014 by the same observer, who received intensive training on the correct application of the WQP beforehand. Farms were selected based on farm size and management (intensive production conditions, forced ventilation, "all in all out" management). Eighty $\%$ of the farms only raised growing pigs, while $20 \%$ had a closed system 
raising sows, piglets and growing pigs. Farm-related data (feeding and hygiene management, prevention of diseases, mortality rate, castration and tail docking routines and procedures) were gathered. All barns were insulated and equipped with mechanical ventilation systems. Liquid feeding was used in $62 \%$ and dry feeding automats in the other farms.

\section{Animal and pen characteristics}

On each farm, 10 randomly selected pens were assessed. In pens with less than 15 pigs, all pigs were included, while in larger pens 15 animals were randomly selected and assessed for the animal-based measures. Hospital pens were excluded and the sex of each individual was recorded. The total number of 600 pens housed 32,723 pigs, of which 8,214 were included in the individual observations. The group size of the selected pens ranged from 10 to 350 animals, which were classified into the following three categories: 1) small: $<15$ pigs/pen; 2) medium: 15 to 30 pigs/pen; and 3) large: > 30 pigs/pen.

Animals were crossbreds of various genetic lines from the following breeding companies: DanZucht (Copenhagen, Denmark) (45\%), German Federal Hybrid Breeding Program (BHZP, Ellringen, Germany) (15\%), Topigs (Senden, Germany) (12.8\%), Pig Improvement Company (PIC) (Schleswig, Germany) (8.3\%), Hypor (Sittensen, Germany) $(6.6 \%)$ or JSR Hybrid (Ahaus, Germany) (3.3\%). Sows were bred by Al either with Pietrain $(73 \%)$ or Duroc $(27 \%)$ semen. Tail docking was routinely practiced for all pigs.

The fattening period started at an initial body weight of $29.9 \pm 2.8 \mathrm{~kg}$ and pigs were slaughtered at $120.8 \pm 3.5 \mathrm{~kg}$. The age of the pigs at the assessment ranged from 12 to 30 weeks. On the assessment day, the actual body weight was calculated based on the initial weight and under the assumption of $800 \mathrm{~g}$ daily weight gain. The respective body weight was classified into the following groups: 1) <50 kg; 2) 50 to $80 \mathrm{~kg}$; and 3) $>80 \mathrm{~kg}$.

The length and width of the individual pens was measured to calculate the space allowance. On average, $0.83 \mathrm{~m}^{2}$ were available per pig (range 0.31 to 2.5 $\mathrm{m}^{2}$ ). In accordance with the German farm animal welfare regulations 
(Tierschutz-Nutztierhaltungsverordnung, 2006) the space allowance was defined as 1) = legally justified: 30 to $50 \mathrm{~kg}=>0.5 \mathrm{~m}^{2} / \mathrm{pig} ; 51$ to $110 \mathrm{~kg}=>0.75$ $\mathrm{m}^{2} / \mathrm{pig} ;>111 \mathrm{~kg}=>1 \mathrm{~m}^{2} / \mathrm{pig}$ or 2 ) = not legally justified: space allowance below the thresholds stated under 1 ).

\section{Assessment of animal-based measures}

At the individual level, body condition, bursitis, manure, wounds, tail biting, lameness, laboured breathing, scouring, skin condition (inflammation or discoloration), hernias, twisted snouts and rectal prolapse were assessed according to the WQP (Welfare Quality $\circledast$, 2009), which includes detailed information on the overall assessment methodology. Only one side of the animals was inspected. Individual animal-based measures are either categorised by a three-point scale ( $0=$ absent, $1=$ moderate, $2=$ severe $)$, such as bursitis, manure on the body, shivering, panting, huddling, lameness, wounds on the body, skin condition and ruptures or else by a two-point scale ( 0 = absent, 2 = present), such as body condition score, tail biting, twisted snouts and rectal prolapse. In brief, score 2 for tail lesions describes the presence of any animal with fresh blood visible on the tail and/or evidence of some swelling and infection, and/or part of the tail tissue missing and presence of crust. For pig dirtiness, score 0 is defined as $<20 \%$, score 1 as $20-50 \%$ and score 2 as $>50 \%$ of the body surface being soiled with faeces. The accordant definitions for bursitis are no evidence of bursa/swelling (score 0), one or several small bursa $(1.5$ to $2.0 \mathrm{~cm}$ ) or one large bursa $(3.0$ to $5.0 \mathrm{~cm}$ ) (score 1) and several large bursa, or one extremely large bursa $(5.0$ to $7.0 \mathrm{~cm})$, or any eroded bursa (score 2). Wounds are scored 0 if the different regions of the body (ears, front, middle, hind-quarters and legs) have less than five lesions. Score 1 is given if 5 to 10 lesions are visible and 2 if more than 11 lesions are observed on at least two body regions or if any zone is found with more than 15 lesions.

At pen level, huddling, shivering, panting, the human-animal relationship and the water supply (number of drinkers, functioning and cleanliness) were assessed. Huddling, shivering and panting were the first measures assessed 
visually from the corridor and only observed in resting animals, just before the animals began to stand up. The human-animal relationship test was performed using score 0 for no panic towards the human present and score 2 for more than $60 \%$ of the pigs with panicking behaviour. Panic was defined as animals fleeing, facing away from the observed or huddling in the pen corner. For the human-animal relationship test, the amount of pens with a panic response from the total pens observed per farm expressed in percent was used for further analysis.

The social and explanatory behaviour was assessed at three different observation points of the farm. At each point 50 to 60 animals from up to four different pens were observed for a total period of 10 minutes with a scan made every 2 minutes. First, the animals were forced to stand up, if necessary hands were clapped, and then they had 5 minutes time to calm down. Firstly, pigs were scored as active or inactive (resting). Active behaviour were differentiated into positive social, negative social, pen investigation, use of enrichment material and other active behaviour. Negative social behaviour is defined as aggressive interaction, including any social behaviour with a response from the disturbed pig. Positive social behaviour is described as sniffing or nosing and moving gently away from the pig without an aggressive reaction. Investigation of the pen is defined as sniffing, nosing or licking all features of the pen, whereby use of enrichment material is described as play or exploring towards enrichment materials. Other active behaviour can be eating, drinking or air sniffing.

\section{Statistical analyses}

All analyses were conducted using SAS version 9.3 (Statistical Analyses System, 2011). Pen was defined as the statistical unit. Results were considered statistically significant at $P>0.05$. For indicators that were recorded at individual level, the number of animals per pen scored either 1 or 2 was divided by the total number of animals observed in the pen and then transformed into frequencies. Data of the social and exploratory behaviour were expressed as the proportion of animals performing the respective behaviour in relation to the 
total number of active animals observed per view point. From seven observation points data could not be included, because pens from more than one group size category were observed at these points.

Multiple Generalized Linear Mixed Models were performed separately for moderate bursitis, manure and wounds as well as for the social and exploratory behaviour using the GLIMMIX procedure. A Poisson distribution and a logarithmic link function were assumed. Apart, scores other than 0 were observed at such low rates that group size effects could not be verified. The statistical model included the fixed effects group size (small, medium and large), live weight group (1, 2 and 3), space allowance (legally justified, not legally justified), and feeding system (liquid feeding, dry feeding) were included. The farm served as random effect to account for the possible dependence between observations of pens from the same farm. Space allowance was excluded because it did not have a significant effect on any of the measures.

For human-animal relationship, which was recorded as binomial variable, odds ratios were calculated using the GLIMMIX procedure including group size as fixed and farm as random effect.

\section{Results}

\section{Farms and animals}

Females and castrates were housed together in mixed pens in more than $60 \%$ of the studied pens, whereas pens with boars and females (6\%) and boars only $(4 \%)$ were exceptions. Sexes were raised separately in all other pens. The vast majority of the pens had a fully and only $8 \%$ a partly slatted floor (Table 1 ). More than $40 \%$ of the pens had a space allowance below the German legal requirements independent of the group size (Table 1). The mean and median number of pigs per drinker was 6 and 7, respectively, for liquid feeding (range 2 to 43 ) and 9 and 10 for dry feeding (range 2 to 23 ). In $22 \%$ of the pens the ratio was larger than 10; and $7 \%$ of the pens were only equipped with one drinker. Three farms using liquid feeding even had no additional drinker in the pen or 
DOES GROUP SIZE HAVE AN IMPACT ON WELFARE INDICATORS IN FATTENING PIGS?

turned them off after a certain period of the fattening period. The mortality rate averaged $2.5 \%$ and ranged from 0.9 to $5.2 \%$. 
Table 1: Distribution (in\% of pens) of floor type (fully-slatted and partly slatted), space allowance (legally justified and not legally justified) and live weight group (1,2 and 3 ) in dependence of three different group sizes (small, medium and large) evaluated in 600 pens for growing pigs

\begin{tabular}{|c|c|c|c|c|c|c|c|c|}
\hline \multirow[b]{2}{*}{ Group size $^{1}$} & \multirow[b]{2}{*}{$\mathrm{n}$} & \multirow{2}{*}{$\begin{array}{l}\text { Floor type } \\
\text { Fully-slatted }\end{array}$} & \multirow[b]{2}{*}{ Partly-slatted } & \multicolumn{2}{|c|}{ Space allowance $^{2}$} & \multicolumn{3}{|c|}{ Live weight group 3} \\
\hline & & & & Legally justified & Not legally justified & 1 & 2 & 3 \\
\hline Small & 207 & 28.8 & 5.7 & 23.0 & 12.1 & 5.9 & 12.1 & 17.0 \\
\hline Medium & 257 & 41.3 & 1.5 & 23.9 & 18.2 & 8.3 & 17.1 & 16.5 \\
\hline Large & 136 & 22.0 & 0.7 & 12.4 & 10.4 & 5.3 & 10.0 & 7.8 \\
\hline Total & 600 & 92.2 & 7.8 & 59.3 & 40.7 & 19.5 & 39.2 & 41.3 \\
\hline
\end{tabular}

${ }^{1}$ Group size: Small: < 15 pigs/pen; medium: 15 to 30 pigs/pen and large: $>30$ pigs/pen.

${ }^{2}$ Space allowance: legally justified $=30$ to $50 \mathrm{~kg}=>0.5 \mathrm{~m}^{2} /$ pig; 51 to $110 \mathrm{~kg}=>0.75 \mathrm{~m}^{2} / \mathrm{pig} ;>111 \mathrm{~kg}=>1 \mathrm{~m} / \mathrm{pig} ;$ not legally justified $=$ space allowance below the thresholds stated under legally justified.

${ }^{3}$ Live weight group: $1=<50 \mathrm{~kg} ; 2=50$ to $80 \mathrm{~kg}$; and $3=>80 \mathrm{~kg}$. 


\section{Animal-based measures}

Among the animal-based measures, highest prevalence was determined for moderate bursitis (35\%), moderate manure $(15.5 \%)$ and moderate wounds $(10.5 \%)$, whereas severe bursitis, manure and wounds were only detected exceptionally (Table 2). For all other indicators recorded at the individual level including tail biting, scores other than 0 were recorded at very low frequencies. In Table 3, rates of the most prevalent measures are presented by group size and live weight class. For moderate bursitis, group sizes did not differ $(P>$ $0.05)$, while the prevalence was higher in the two upper live weight classes when compared with the lowest class $(P<0.05)$. In medium and large groups moderately soiled bodies were found more often than in small groups $(P<$ $0.05)$. Moderate manure was found at higher rates on pigs fed by a liquid $(22 \%)$ than a dry feeding system $((12 \%) ; P<0.05)$. Pigs in the upper two live weight classes were dirtier than in the lowest class $(P<0.05)$. Moderate wounds increased from less than $9 \%$ in small to almost $16 \%$ in large groups $(P<0.05)$. In comparison to pigs in the medium live weight category, moderate wounds were less often observed in pigs of the upper one $(P<0.05)$. 
Table 2: Prevalence (\%) of the animal-based measures of the Welfare Quality $₫$ assessment protocol for growing pigs evaluated in 600 pens

\begin{tabular}{|c|c|c|c|c|c|}
\hline Measure & Mean & SD & Median & Min & Max \\
\hline Poor body condition & 0.2 & 0.7 & 0 & 0 & 17 \\
\hline Moderate bursitis & 34.7 & 8.9 & 33 & 0 & 93 \\
\hline Severe bursitis & 2.7 & 3.3 & 0 & 0 & 47 \\
\hline Moderate manure & 15.5 & 9.8 & 13 & 0 & 88 \\
\hline Severe manure & 6.2 & 6.5 & 0 & 0 & 100 \\
\hline Moderate lameness & 0.4 & 0.6 & 0 & 0 & 13 \\
\hline Severe lameness & 0.1 & 0.3 & 0 & 0 & 11 \\
\hline Moderately wounded & 10.5 & 7.5 & 7 & 0 & 64 \\
\hline Severely wounded & 1.5 & 2.8 & 0 & 0 & 50 \\
\hline Tail biting & 1.9 & 2.8 & 0 & 0 & 90 \\
\hline Pumping & 0.0 & 0.1 & 0 & 0 & 7 \\
\hline Twisted snouts & 0.0 & 0.0 & 0 & 0 & 0 \\
\hline Rectal prolapse & 0.0 & 0.1 & 0 & 0 & 7 \\
\hline Moderate skin & 0.6 & 0.8 & 0 & 0 & 13 \\
\hline Severe skin & 0.0 & 0.1 & 0 & 0 & 7 \\
\hline Moderate hernia & 0.6 & 0.7 & 0 & 0 & 13 \\
\hline Severe hernia & 0.0 & 0.0 & 0 & 0 & 7 \\
\hline Panic response & 14.5 & 17.8 & 0 & 0 & 100 \\
\hline
\end{tabular}


Table 3: Prevalence (\%) (standard error) of selected animal-based measures of the Welfare Quality® protocol for growing pigs separated by group size (small, medium and large) and live weight group (1,2 and 3) evaluated in 600 pens

\begin{tabular}{lllllll}
\hline Measures & \multicolumn{5}{l}{ Group size $^{1}$} & \multicolumn{5}{c}{ Live weight group $^{2}$} \\
\cline { 2 - 7 } & Small & Medium & Large & 1 & 2 & 3 \\
\hline Moderate bursitis & $32.6(1.6)$ & $33.1(1.6)$ & $34.7(2.0)$ & $25.8^{\mathrm{a}}(1.9)$ & $36.5^{\mathrm{b}}(1.7)$ & $38.1^{\mathrm{b}}(1.6)$ \\
Moderate manure & $10.4^{\mathrm{a}}(1.4)$ & $13.1^{\mathrm{ab}}(1.5)$ & $15.8^{\mathrm{b}}(1.8)$ & $9.7^{\mathrm{a}}(1.7)$ & $15.4^{\mathrm{b}}(1.5)$ & $14.2^{\mathrm{b}}(1.5)$ \\
Moderate wounds & $8.5^{\mathrm{a}}(1.2)$ & $11.3^{\mathrm{a}}(1.2)$ & $16.3^{\mathrm{b}}(1.5)$ & $14.4^{\mathrm{a}}(1.4)$ & $12.5^{\mathrm{a}}(1.3)$ & $9.3^{\mathrm{b}}(1.2)$
\end{tabular}

a,b,c Different letters within rows indicate significant differences $(P<0.05)$.

${ }^{1}$ Group size: Small: $<15$ pigs/pen; medium: 15 to 30 pigs/pen and large: $>30$ pigs/pen.

${ }^{2}$ Live weight group: $1=<50 \mathrm{~kg}$; $2=50$ to $80 \mathrm{~kg}$; and $3=>80 \mathrm{~kg}$. 
The effects of group size and live weight group on the social and exploratory behaviour are presented in Table 4 . At a rate of $4.3 \%$, negative social behaviour was recorded more frequently in large groups $(P<0.05)$ than in small $(2.2 \%)$ and medium groups $(2.4 \%)$. Without differences between groups, a positive social behaviour was observed at rates of around $10 \%$. Also not different between groups, rates of 22 to $25 \%$ were found for investigation of the pen and 3 to $4 \%$ for exploration of enrichment material. Pigs in large groups showed active behaviour less frequent than those in small and medium groups $(P<$ 0.05). Regarding live weight groups, differences were only found for investigation of the pen, which was recorded more often in group 1 and 2 than in group $3(P<0.05)$.

The prevalence of a panic response assessed via human-animal relationship was higher in small (20.3\%) than in medium (14.0\%) and large groups (6.6\%; Table 5). Thereby, the odd of having a panic response was 0.329 and 0.497 for pigs in small and medium groups, respectively, when compared to large groups. 
Table 4: Prevalence (\%) (standard error) of the social and exploratory behaviour separated by group size (small, medium and large) and live weight group (1,2 and 3) evaluated in 600 pens

\begin{tabular}{|c|c|c|c|c|c|c|}
\hline \multirow[t]{2}{*}{ Measures } & \multicolumn{3}{|l|}{ Group size $^{1}$} & \multicolumn{3}{|c|}{ Live weight group ${ }^{2}$} \\
\hline & Small & Medium & Large & 1 & 2 & 3 \\
\hline Negative social & $2.2^{\mathrm{a}}(0.3)$ & $2.4^{a}(0.3)$ & $4.3^{\mathrm{b}}(0.4)$ & $2.9(0.3)$ & $2.8(0.3)$ & $2.9(0.3)$ \\
\hline Positive social & $9.2(0.6)$ & $10.1(0.6)$ & $11.6(0.9)$ & $10.6(0.6)$ & $9.9(0.5)$ & $10.5(0.4)$ \\
\hline Investigation of the pen & $24.5(1.3)$ & $23.4(1.2)$ & $21.7(1.8)$ & $24.8^{a}(1.3)$ & $24.3^{a}(0.8)$ & $20.9^{b}(0.8)$ \\
\hline Exploration of enrichment material & $3.4(0.5)$ & $3.6(0.5)$ & $3.4(0.7)$ & $3.6(0.5)$ & $3.4(0.3)$ & $3.2(0.3)$ \\
\hline Active behaviour & $60.5^{\mathrm{a}}(1.7)$ & $60.3^{\mathrm{a}}(1.6)$ & $54.7^{\mathrm{b}}(2.3)$ & $61.9(1.7)$ & $59.1(1.2)$ & $59.4(1.2)$ \\
\hline
\end{tabular}

a,b,c Different letters within rows indicate significant differences $(P<0.05)$.

${ }^{1}$ Group size: Small: $<15$ pigs/pen; medium: 15 to 30 pigs/pen and large: $>30$ pigs/pen.

${ }^{2}$ Live weight group: $1=<50 \mathrm{~kg} ; 2=50$ to $80 \mathrm{~kg}$; and $3=>80 \mathrm{~kg}$ 
Table 5: Probability of occurrence of a panic response to the observer depending on group size (small, medium and large) evaluated in 600 pens

\begin{tabular}{|c|c|c|c|c|}
\hline Variable & \multicolumn{2}{|l|}{ panic response (\%) } & \multicolumn{2}{|c|}{$\begin{array}{l}\text { Confidence } \\
\text { intervals (95\%) }\end{array}$} \\
\hline \multicolumn{5}{|l|}{ Group size ${ }^{2}$} \\
\hline Small & 20.3 & 0.329 & 0.119 & 0.908 \\
\hline Medium & 14.0 & 0.497 & 0.188 & 1.313 \\
\hline Large & 6.6 & Reference & - & - \\
\hline
\end{tabular}

\section{Discussion}

Among the various indicators that were assessed using the WQP bursitis, wounds and manure on the pigs showed the highest incidences. In large groups of more than 30 animals, the presence of both wounded and soiled pigs was higher compared to small- and medium-sized groups. Additionally, negative social behaviour was found more often in large groups, in which, on the contrary, a better human-animal relationship was noted. With increasing live weight, the occurrence of bursitis and manure on the body increased, while the prevalence of wounds and exploration of enrichment material decreased.

\section{Feeding}

Under conventional fattening conditions where animals are commonly fed ad libitum, pigs with a poor body condition are the exception. Expectedly, values in our study were similar to those observed by Temple et al. (2012) who recorded a prevalence of only $0.4 \%$ in conventional production systems. Even though previous studies showed that access to feeders and feed intake is impacted by group size (Spoolder et al., 1999; Wolter et al., 2001), changes are not as 
pronounced as to translate directly into body condition changes. In general, a poor body condition is the result of deficits in health management and consequently in feed intake (Velarde \& Geers, 2007). However, it has to be mentioned here that hospital pens are not assessed by the WQP, thus the actual prevalence in the studied farms might have been greater.

Contrary to feeding, the water supply was regularly insufficient in terms of animal to drinker ratio and functionality. In accordance with article 28 (2) No 5 (Tierschutz-Nutztierhaltungsverordnung, 2006) one drinker should be offered per 12 pigs and article 26 (1) No 2 regulates that every pig should have permanent access to a drinker with water in sufficient quality and quantity and which is separated from the feeding spaces. Nevertheless, the ratio should be adjusted to the group size. As the interaction between group size and drinker ratio on daily time at the drinkers found by Turner et al. (2000) indicated. Consequently, the larger the group the more drinkers per pig should be available, although pigs in larger groups (60 pigs) spent less time drinking per day than pigs in smaller groups ( $<20$ pigs). Furthermore, the frequency of visits to the drinkers, drinking bout duration and daily drinking time increased in the mentioned study when the pig to drinker ratio increased (Turner et al., 2000). However, a sufficient quantity is more often a problem than the water quality (Kamphues \& Schulz, 2002).

\section{Bursitis}

Bursitis arises as one or more fluid-filled sacs at the fore or hind leg, where normally no swelling is present. The swelling occurs whenever skin covering a bony structure is exposed to pressure and is not related to an infection. As a result, the fluid exudates from traumatized capillaries and lymphatic vessels. Bursitis can persist or vanish after a certain period of time (Mouttotou et al., 1999). In the present study moderate bursitis (35\%) was found as the most prevalent animal-based measure. As shown in previous studies, this is a sensitive indicator to compare different production systems and differentiate farms, because of high between-farm variability and low within-farm variability 
(Temple et al., 2012). When bursitis was present on a farm, a large number of animals were affected. The different prevalence of bursitis and the high between-farm variability can be explained by several causal factors such as the environment, especially the floor type. A concrete floor increases pressure on the pigs' limbs and intensifies the severity of bursitis (Smith, 1993; Mouttotou et al., 1999). The high bursitis prevalence in the present study can be explained by the vast majority of pens with fully slatted floors. However, differences between fully and partly slatted floors could not be verified. The prevalence of bursitis increased with age during the fattening period, mainly due to the fact that the greater body weight exerts additional pressure on the limbs (Mouttotou et al., 1999). Although Smith (1993) reported that pigs kept at high stocking densities tended to have an increased prevalence and severity of bursa lesions, the stocking density and group size in our study did not have an effect. Although we observed that more than $40 \%$ of the farms had a space allowance below the German farm animal welfare regulations (TierschutzNutztierhaltungsverordnung, 2006), this did not affect the prevalence of bursitis. Severe bursitis was only recorded exceptionally and at lower rates than under comparable production conditions with concrete flooring in previous studies (Temple et al., 2011a).

\section{Pig dirtiness}

The prevalence of moderately (15.5\%) and severely (6.2\%) soiled bodies are similar to the values of $16.6 \%$ and $3.7 \%$, respectively, reported by Temple et al. (2011a). This emphasizes that the prevalence of soiled bodies is consistent within the same production system independent of the geographic region. The highest prevalence of moderate dirtiness was registered for pigs kept in large groups $(15.8 \%)$, compared to the lowest in small groups (10.4\%). Comparable values are not available in the literature, yet. Pig dirtiness is influenced by multiple factors (Velarde \& Geers, 2007) with the floor type being one of the most causal factors in conventional housing systems (Temple et al., 2011a). Thereby, the risk for manure on the body is higher for partly than for fully slatted 
floors (Temple et al., 2012). However, this could not be verified in our study. Similar to bursitis, pig dirtiness increased during the fattening period, which can be mainly explained by the fact that the effective stocking density increases. Furthermore, older pigs spend more time lying compared to younger animals in order to dissipate metabolic heat (Aarnink et al., 2006). This was supported by the current finding that older pigs were found less often investigating the pen compared with younger animals. As another determining factor, the feeding system plays a role. The findings that liquid-fed pigs were dirtier than dry-fed ones was previously described by Hyun (2001). In summary, the feeding system and floor type seem to have a much larger effect on pig dirtiness than group size.

\section{Wounds}

The prevalence of severely wounded pigs $(1.5 \%)$ was similar to the mean prevalence found by Temple et al. (2011a). The occurrence of moderate wounds was about $10.5 \%$. With increasing group size, the amount of observed moderate wounds rose. It remains questionable whether these wounds are a consequence of social interactions between animals (fights) or deficiencies in the physical environmental (inappropriate design of facilities). Moreover, negative social behaviour occurred more often with increasing group size in the present study. In general, negative social behaviour is a clear indicator of poor welfare, whereas the occurrence in the present study was found at a level as low as reported by Temple et al. (2011b). The number of possible encounters increases with increasing group size and consequently the risk for agonistic behaviour and injures increases (Velarde \& Geers, 2007). Similar to our findings, McGlone \& Newby (1994) observed the highest injury and morbidity rate in groups of 40 compared with 20 or 10 pigs.

The decreasing prevalence of wounds with increasing age during the fattening period is probably due to the fact that wounds are usually achieved at the beginning of the fattening period as a result of fights during the establishment of the rank order. These fights can be of differing severity and length depending 
on the aggressiveness of individual group members (Bryant \& Ewbank, 1972). Furthermore, competition for food leads to more wounds (Botermans \& Svendsen, 2000). In fact, dry feeding with limited feeding places compared with liquid feeding using communal troughs led to an increase in skin injuries, most pronounced when the pigs were fed restrictively. In agreement, pigs fed by a dry feeder with a reduced number of feeding places, showed a higher incidence of moderate wounds in our study. Though the incidence of wounds is highly dependent on whether pigs are fed ad libitum or restricted, lesion patterns on the skin do act as indicators for welfare and reflect the quality of pigs' social and physical environment. This is particularly valid under the consideration that fattening pigs are most commonly fed ad libitum.

\section{Behaviour}

In general, behaviour is an important component of animal welfare because it reflects the animal's feeling. Therefore, it plays a major role in the WQP. To the author's knowledge this is the first study, revealing the relationship between group size and social and exploratory behaviour. The fact that large groups showed more negative social behaviour, which is a clear indicator of insufficient welfare, emphasizes the increased number of stressful situations and competition for resources in these groups. Nevertheless, it has to be noted that differences between groups were relatively low and the overall presence of this indicator was lower than observed by other studies under comparable production systems (Temple et al., 2011b). For investigation of the pen, differences between groups sizes were not observed, so the proposed increase in negative social behaviour associated with a decrease of exploratory behaviour by Temple et al. (2011b) could not be substantiated. The proportion of exploratory behaviour including investigation of the pen and exploration of enrichment material in our as well as previous studies (Temple et al., 2011b) clearly indicates that under intensive fattening conditions the behavioural needs are not fulfilled. This becomes obvious when comparisons to extensive housing conditions where exploratory behaviour is performed at much higher rates 
(40\%) are drawn (Temple et al., 2011b). The decrease of the exploration behaviour during the fattening period is probably due to a lower level of curiosity and higher level of lethargy (Studnitz et al., 2007). In contrast to negative, positive social behaviour was observed at higher frequencies without any difference between group sizes. It reduces the negative effects of stressful events and hence is related to good welfare (Temple et al., 2011b). However, a social interaction may begin as a positive one (i.e. licking) and end up in a negative one (i.e. biting). Therefore, high levels of positive social activity may not necessarily reflect a positive mood of the animal (Boissy et al., 2007). In consequence, the interpretation of high frequencies of positive social behaviour should be carefully interpreted (Temple et al., 2011b).

The human-animal relationship is largely affected by the way farmers interact with their animals (Hemsworth et al., 1993). With the help of this parameter it is possible to detect the fear response of the pigs toward the stockman. Fear is considered as a major welfare problem and alters not only the well-being, but also the productivity, product quality and profitability of farm animals (Waiblinger et al., 2006). Without changes in husbandry conditions, human-animal relationship is consistent for a prolonged period on the farm (Temple et al., 2011b). In total, a panic response was observed in $14.5 \%$ of the pens in the present study. According to Temple et al. (2011b), a farm with maximum $30 \%$ of the pens showing a panic response can be considered having a good welfare status for the relationship between animal and farmer. Apart from an adequate interaction, there are other important factors influencing the human-animal relationship such as the genetics, growing stage, rearing system (Waiblinger et al., 2006) or feed supply (Hemsworth et al., 1993). Indeed, results might be biased by the fact that in small pens pigs cannot escape from the observer as easily as in large pens. Another explanation might be that in large pens farmers have to walk through the pens for their routine controls, and thus pigs might receive more frequent human contact. 


\section{Tail biting and other indicators}

As one of the most common welfare problems in the pig industry (SchrøderPetersen \& Simonsen, 2001), tail biting has welfare implications not only for the bitten pigs suffering from pain, but also for the biters being unable to cope with their environment (D'Eath et al., 2014). Economic losses are caused by reduced weight gain, extra handling and medication costs, whereas determining factors are complex and can vary over time (Taylor et al., 2010). When pigs are taildocked and tail biting is occurring as rarely as observed in this as well as the study of Temple et al. (2011a), group size does not seem to be risk factor. Nevertheless, it has to be emphasized that docked pigs are less bitten than undocked pigs, even though it does not prevent tail biting behaviour completely (Moinard et al., 2003).

The low occurrence $(<2 \%)$ of the indicators lameness, hernia, panting, laboured breathing, shivering, huddling, and scouring in growing pigs kept under intensive conditions found here and by Temple et al. (2011a), limited the potential of these measures to differentiate group sizes. Again, it has to be mentioned that hospital pens were not observed and this might have affected the prevalence. However, the prevalence of these indicators not only reflects health problems but also problems in the management of the hospital pens (Temple et al., 2011a).

\section{Conclusion}

Findings of the present study showed the effects of different group sizes in fattening pigs on several animal-based measures. However, none of the group sizes proved to be superior to others. In pens with more than 30 animals the presence of wounded and dirty pigs and of negative social behaviour was greater. On the contrary, a better human-animal relationship was noted in these large groups. 


\section{Acknowledgements}

The study was supported by the PhD-Program "Animal Welfare in Intensive Livestock Production Systems" funded by Lower Saxony, Germany. The authors are grateful to Dr. Karl-Heinz Tölle, Dr. Conrad Welp, Dr. Jörg Bauer, Martin Knees, Georg Freisfeld, Gert Stelling and all the farmers for their cordial collaboration.

\section{References}

Aarnink A.J.A., Schrama J.W., Heetkamp M.J.W., Stefanowska J. \& Huynh T.T.T. 2006. Temperature and body weight affect fouling of pig pens. Journal of Animal Science 84: 2224-2231

Averós X., Brossard L., Dourmad J.Y., de Greef K.H., Edge H.L., Edwards S.A. \& Meunier-Salaün M.C. 2010. Quantitative assessment of the effects of space allowance, group size and floor characteristics on the lying behaviour of growing-finishing pigs. Animal 4: 777-783

Boissy A., Manteuffel G., Jensen M.B., Moe R.O., Spruijt B., Keeling L.J., Winckler C., Forkman B., Dimitrov I., Langbein J., Bakken M., Veissier I. \& Aubert A. 2007. Assessment of positive emotions in animals to improve their welfare. Physiology and Behavior 22: 375-397

Botermans J.A.M. \& Svendsen J. 2000. Effect of feeding environment on performance, injuries and behaviour in growing-finishing pigs: Groupbased studies. Acta Agriculturae Scandinavica 50: 237-249

Bryant M.J. \& Ewbank R. 1972. Some effects of stocking rate and group size upon agonistic behaviour in groups of growing pigs. British Veterinary Journal 128: 64-70 
D'Eath R.B., Arnott G., Turner S.P., Jensen T., Lahrmann H.P., Busch M.E., Niemi J.K., Lawrence A.B. \& Sandoe P. 2014. Injurious tail biting in pigs: how can it be controlled in existing systems without tail docking? Animal 8: $1479-1497$

FAWC 2012. Report on Farm animal welfare: Health and disease. Farm Animal Welfare Committee, Department for Environment, Food and Rural Affairs, London, United Kingdom: 1-72

Gonyou H.W. 2001. The social behaviour of pigs. In Social behaviour in farm animals CABI Publishing, Wallingford, United Kingdom, 147-176

Hemsworth P.H., Barnett J.L. \& Coleman G.J. 1993. The human-animal relationship in agriculture and its consequences for the animal. Animal Welfare 2: 33-51

Hoy S., Gauly M. \& Krieter J. 2006. Nutztierhaltung und -hygiene, Grundwissen Bachelor. Ulmer Eugen Verlag, Stuttgart, Germany, 125-133

Hyun Y. 2001. Effect of group size and feeder type on growth performance and feeding patterns in growing pigs. Journal of Animal Science 79: 803-810

Kamphues J. \& Schulz I. 2002. Field relevant aspects of the water supply in food producing animals. Übersichten zur Tierernährung - Survey of Animal Nutrition 30: 65-107

Kayser M., Schlieker K. \& Spiller A. 2012. Die Wahrnehmung des Begriffs "Massentierhaltung" aus Sicht der Gesellschaft. Berichte über Landwirtschaft 90: 417-427

McGlone J. \& Newby B. 1994. Space requirements for finishing pigs in confinement: behavior and performance while group size and space vary. Applied Animal Behaviour Science 39: 331-338 
Moinard C., Mendl M., Nicol C.J. \& Green L.E. 2003. A case control study of onfarm risk factors for tail biting in pigs. Applied Animal Behaviour Science 81: $333-355$

Mouttotou N., Hatchell F.M. \& Green L.E. 1999. Prevalence and risk factors associated with adventitious bursitis in live growing and finishing pigs in south-west England. Preventive Veterinary Medicine 39: 39-52

Samarakone T.S. \& Gonyou H.W. 2008. Productivity and aggression at grouping of grower-finisher pigs in large groups. Canadian Journal of Animal Science 88: 9-17

Schmolke S.A., Li Y.Z. \& Gonyou H.W. 2003. Effect of group size on performance of growing-finishing pigs. Journal of Animal Science 81: 874-878

Schrøder-Petersen D.L. \& Simonsen H.B. 2001. Tail biting in pigs. The Veterinary Journal 162: 196-210

Schröder M.J.A. \& McEachern M.G. 2004. Consumer value conflicts surrounding ethical food purchase decisions: a focus on animal welfare. International Journal of Consumer Studies 28: 168-177

Smith W.J. 1993: A study of adventitious bursitis of the pig hock. Doctor of Veterinary Medicine and Surgery. University of Edinburgh, United Kingdom, Edinburgh, United Kingdom.

Spoolder H.A.M., Edwards S. \& Corning S. 1999. Effects of group size and feeder space allowance on welfare in finishing pigs. Animal Science 69: $481-489$

Studnitz M., Jensen M.B. \& Pedersen L.J. 2007. Why do pigs root and in what will they root?: A review on the exploratory behaviour of pigs in relation to environmental enrichment. Applied Animal Behaviour Science 107: 183197 
Taylor N.R., Main D.C.J., Mendl M. \& Edwards S.A. 2010. Tail-biting: A new perspective. The Veterinary Journal 186: 137-147

Temple D., Dalmau A., Ruiz de la Torre J., Manteca X. \& Velarde A. 2011a. Application of the Welfare Quality ${ }^{\circledR}$ protocol to assess growing pigs kept under intensive conditions in Spain. Journal of Veterinary Behaviour: Clinical Applications and Research 6: 138-149

Temple D., Manteca X., Velarde A. \& Dalmau A. 2011b. Assessment of animal welfare through behavioural parameters in lberian pigs in intensive and extensive conditions. Applied Animal Behaviour Science 131: 29-39

Temple D., Courboulay V., Manteca X., Velarde A. \& Dalmau A. 2012. The welfare of growing pigs in five different production systems: assessment of feeding and housing. Animal 6: 656-667

Tierschutz-Nutztierhaltungsverordnung 2006. Verordnung zum Schutz landwirtschaftlicher Nutztiere und anderer zur Erzeugung tierischer Produkte gehaltener Tiere bei ihrer Haltung (TierschutzNutztierhaltungsverordnung - TierSchNutztV) in der Fassung der Bekanntmachung vom 22. August 2006, Bundesgesetzblatt Jahrgang 2006 Teil I Nr. 41, ausgegeben zu Bonn, Germany, am 31. August 2006, (BGBI. I S. 2053).

Turner S.P., Sinclair A.G. \& Edwards S.A. 2000. The interaction of liveweight and the degree of competition on drinking behaviour in growing pigs at different group sizes. Applied Animal Behaviour Science 67: 321-334

Turner S.P. \& Edwards S.A. 2004. Housing immature domestic pigs in large social groups: implications for social organisation in a hierarchical society. Applied Animal Behaviour Science 87: 239-253

Velarde A. \& Geers R. 2007. On farm monitoring of pig welfare. Wageningen Academic, Wageningen, Netherlands, 53-121 
Velarde A., Fabrega E., Blanco-Penedo I. \& Dalmau A. 2015. Animal welfare towards sustainability in pork meat production. Meat Science 109: 13-17

Waiblinger S., Boivin X., Pedersen V., Tosi M.-V., Janczak A.M., Visser E.K. \& Jones R.B. 2006. Assessing the human-animal relationship in farmed species: A critical review. Applied Animal Behaviour Science 101: 185242

Welfare Quality ${ }^{\circledR}$ 2009. Welfare Quality ${ }^{\circledR}$ assessment protocol for pigs (sow and piglets, growing and finishing pigs). Welfare Quality $®$ Consortium, Lelystad, The Netherlands

Wolter B.F., Ellis M., Curtis S.E., Augspurger N.R., Hamilton D.N., Parr E.N. \& Webel D.M. 2001. Effect of group size on pig performance in a wean-tofinish production system. Journal of Animal Science 79: 1067-1073 


\section{KAPITEL 6}

Allgemeine Diskussion 


\section{$6 \quad$ Allgemeine Diskussion}

\subsection{Einleitung}

Im Rahmen der vorliegenden Dissertation sollten Ergebnisse erarbeitet werden, um die in der Öffentlichkeit zunehmend emotional geführte Diskussion um Defizite im Tierschutz bei wachsenden Bestandsgrößen zu versachlichen. Insgesamt wurden 60 konventionelle Schweinemastbetriebe mit Hilfe des Welfare Quality® Protokolls für Schweine (Welfare Quality®, 2009) bewertet. Damit sollte Auskunft über das Tierwohl konventioneller Schweinemastbetriebe gegeben werden. Der Schwerpunkt der Arbeit lag auf der Fragestellung, ob die Bestandsgröße einen Einfluss auf das Wohl der Tiere hat. Insbesondere wurde dieser Effekt auf das Tierverhalten (Erleben positiver Emotionen) untersucht. Abschließend wurde überprüft, ob es einen Zusammenhang zwischen der Gruppengröße und ausgewählten Tierwohlindikatoren des Welfare Quality® Protokolls gibt.

Die Betriebsakquise fand in erster Linie über den ISN (Interessengemeinschaft Norddeutscher Schweinhalter e.V.) statt. Die teilnehmenden Betriebe waren in verschiedenen Erzeugergemeinschaften bzw. Beratungsringen organisiert und wurden von ihrem jeweiligen Berater akquiriert. Die Teilnahme an der Studie erfolgte auf freiwilliger Basis, wobei die Respons-Rate 100\% betrug. Inwiefern die Auswahl der Betriebe durch den zuständigen Berater einen Effekt auf das Ergebnis dieser Untersuchung hat, ist schwer abzuschätzen.

Haltungsverfahren waren Voll- (92\%) und Teilspaltenböden (8\%). 2010 wurden in Deutschland $67 \%$ der Schweine auf Voll- und $25 \%$ auf Teilspaltenböden, die restlichen auf planbefestigten Boden mit Einstreu (6\%) und anderen Stallhaltungsverfahren (2\%) (WBA, 2015) gehalten. Damit sind die Betriebe mit Vollspaltenböden in dieser Studie überrepräsentiert. 


\subsection{Zusammenhang zwischen Bestandsgröße und Tierwohl}

Unter Berücksichtigung der Betriebsgrößenentwicklungen der Schweineproduktion in Deutschland und in Anlehnung an die Einteilung der Betriebe nach dem Bundesimmissionsschutzgesetz wurden die teilnehmenden Betriebe in die drei Bestandsgrößen-Kategorien klein ( $<1.500$ Mastplatze), mittel (1.500 - 3.000 Mastplätze) und groß (> 3.000 Mastplätze) eingeteilt. In Deutschland beträgt die durchschnittliche Bestandsgröße 1.037 Schweine pro Betrieb (Statistisches Bundesamt, 2014). Nach Kayser et al. (2012) gehen 90\% der Verbraucher ab 1.000 Schweinen pro Betrieb von Massentierhaltung aus. Dies ist bei der Interpretation der Ergebnisse zu berücksichtigen, da Betriebe der kleinsten Bestandsgrößen-Kategorie bis zu 1.500 Mastplätze haben können. Darüber hinaus kamen Schwierigkeiten bei der Auswahl einer größeren Zahl von Betrieben, die das gesamte Betriebsgrößenspektrum abdecken, hinzu. Gerade in der großen Bestandsgrößen-Kategorie war es schwierig, eine repräsentative Stichprobe zu ziehen. So ist die Spanne der großen Bestandsgrößen-Kategorie Betriebe mit 3.000 bis 11.000 Mastplätzen vergleichsweise weit.

Annähernd $80 \%$ der Betriebe wurden als "verbessert" klassifiziert; alle anderen Betriebe als „akzeptabel“. Abweichend vom Welfare Quality® Protokoll für Schweine wurde nicht nur in die vorgeschriebenen Klassen "exzellent", „verbessert", „akzeptabel“ und „nicht klassifiziert" eingeteilt, sondern zusätzlich eine Durchschnitts-Bewertung eingeführt, um die Einstufung hinsichtlich des Tierwohl-Niveaus anschaulicher zu gestalten. Der Durchschnittscore betrug 54,8 von 100 Punkten bei einer Spanne von 39,5 bis 66,2 von 100 Punkten. Grundsätzlich ist das Tierwohl-Niveau damit als eher niedrig einzustufen. Vergleichbare Studien gibt es kaum. Otten et al. (2013) untersuchte drei Schweinemastbetriebe mit Hilfe des Welfare Quality ${ }^{\circledR}$ Protokolls und dokumentierte ähnlich niedrige Werte für den Gesamtscore.

Die Bestandsgröße hatte keinen signifikanten Effekt auf die Ausprägung des Gesamtscores sowie des Durchschnittsscores. Knage-Rasmussen et al. (2013) 
stellten ebenfalls keinen Zusammenhang zwischen der Anzahl Mastschweine pro Betrieb (120 bis 7.825 Schweine/Betrieb) und einem Welfare Index, bestehend aus Verhaltens- und Gesundheitsindikatoren, fest. Auf Ebene der vier Grundsätze und 12 Kriterien des WQP konnten keine signifikanten Unterschiede zwischen den drei Bestandsgrößen-Kategorien abgesichert werden. Zwischen der Ausprägung der einzelnen Grundsätze und Kriterien gibt es allerdings Unterschiede.

Der Grundsatz „Gute Fütterung“ erzielte die höchste Punktzahl. Dies kann durch die hohe Punktzahl des Kriteriums „Abwesenheit von Hunger" erklärt werden. Dieses Kriterium wird ausschließlich durch den Indikator „Körperkondition“ bestimmt. Im Rahmen der Einzeltieruntersuchungen wurden nur $0,2 \%$ der Schweine mit einer schlechten Körperkondition beobachtet, das den hohen Score für das Kriterium begründet. Die Körperkondition ist nach Temple et al. (2011a) ein Parameter, der erst bei der Bewertung von extensiven Haltungssystemen zum Tragen kommt. Dort ist der Zugang zu Futterressourcen nicht so kontrollierbar wie in der konventionellen Mast. Demnach ist dieser Parameter bei Vergleichen von konventionellen Haltungsbedingungen nicht sinnvoll einsetzbar. Fragwürdig ist, ob eine gute Fütterung ausschließlich über die Körperkondition bewertet werden kann. Eine Fütterungstechnik, die einen adäquaten Beitrag zum Tierwohl leisten soll, basiert nicht ausschließlich auf der Befriedigung von Durst und Hunger. Neben der Deckung des Energiebedarfs spielt die Befriedigung der Nahrungssuche eine Rolle (Day et al., 1995). Futter aus einer Flüssigfütterung, wie sie in dieser Studie auf fast zwei Drittel der Betriebe angeboten wurde, ist rasch verzehrt. Ein positiver Beschäftigungseffekt durch Futtersuche und -aufnahme entfällt.

Das Kriterium „Abwesenheit von Durst" erreichte aufgrund teilweise erheblicher Mängel bei der Wasserversorgung nicht die volle Punktzahl. Bei einer zu hohen Anzahl Tiere pro Tränke besteht die Gefahr, dass rangniedere Tiere nicht ausreichend mit Wasser versorgt werden. Eine ausreichende Anzahl an Tränken und entsprechende Verfügbarkeit von Trinkwasser ist nach Kamphues \& Schulz (2002) deutlich häufiger ein Problem als die Wasserqualität an sich. 
Otten et al. (2013) konnte ebenfalls eine mangelhafte Trinkwasserversorgung auf den untersuchten Betrieben dokumentieren. Die teilweise mangelnde Verfügbarkeit von Tränken war unabhängig von der Bestandsgröße.

Der Grundsatz "Gute Haltung“ wurde schlechter bewertet als der Grundsatz "Gute Fütterung". Er setzt sich aus den drei Kriterien "Liegekomfort", „Klimakomfort" und "Bewegungsfreiheit" zusammen. Das Kriterium „Liegekomfort" wird mit Hilfe des Verschmutzungsgrades und dem Vorkommen von Bursitis bewertet. Im Mittel waren auf den 60 Betrieben insgesamt 34,7\% der Schweine von moderater Bursitis betroffen. Damit war Bursitis der am häufigsten vorkommende Indikator. Die Bildung von Bursitis gilt allgemein als eine Reaktion auf suboptimale Haltungsbedingungen (KilBride et al., 2008). Das Ausmaß der damit verbundenen Schmerzen ist jedoch nicht geklärt. Haupteinflussfaktor ist vor allem die Art und Qualität des Stallbodens (Lyons et al., 1995; Scott et al., 2006; Gillman et al., 2008; KilBride et al., 2008). Die Prävalenz nimmt auf harten (Spalten, einstreulos) bis hin zu weichen (Stroh, Sand etc.) Böden ab, sowie mit steigendem Alter bzw. Gewicht. Das Vorkommen von Bursitis unterscheidet sich nicht signifikant zwischen den drei Bestandsgrößen-Kategorien. Ursächlich hierfür könnte sein, dass der Anteil von Buchten mit Teilspaltenböden und verschiedene Altersgruppen gleichmäßig über die drei Bestandsgrößen-Kategorien verteilt war. Temple et al. (2011a) beschreiben moderate Bursitis als einen sensitiven Parameter, der zur Differenzierung von Betrieben herangezogen werden kann. Abgeleitet wurde dies von einer hohen Variabilität der Ergebnisse zwischen den Betrieben und einer geringen Variabilität innerhalb des jeweiligen Betriebes. Diese Einschätzung wurde durch die vorliegenden Ergebnisse bestätigt.

Der Verschmutzungsgrad der Tiere nahm signifikant mit steigender Bestandsgröße zu $(p<0,05)$. Kontakt zwischen den Exkrementen und den Schweinen ist zu vermeiden, da ein hoher Verschmutzungsgrad mit Kot sich negativ auf die Gesundheit der Tiere auswirken kann. Vergleichbare Verschmutzungsgrade wurden von Temple et al. (2011a) dokumentiert. Das Fütterungssystem und die Art des Bodens werden in der Literatur als mögliche 
Einflussfaktoren auf den Verschmutzungsgrad der Tiere diskutiert. Nach Scott et al. (2007) und Temple et al. (2012b) erhöht Flüssigfütterung gegenüber Trockenfütterungen das Risiko für leichte Verschmutzungen. In dieser Studie wurde mit steigender Bestandsgröße häufiger eine Flüssigfütterung eingesetzt. Dies könnte das erhöhte Vorkommen von verdreckten Tieren auf größeren Betrieben erklären. Bezüglich der Art des Bodens beschreiben Scott et al. (2006) und Temple et al. (2012a) einen hohen Anteil an Spalten als einen begünstigenden Faktor für sauberere Tiere. Teilspaltenböden verschlechterten den Hygienestatus, was in diesem Versuch bestätigt werden konnte. Auf Teilspaltenböden gehaltene Tiere waren signifikant stärker verschmutzt als Tiere auf Vollspalten. Allerdings muss berücksichtigt werden, dass insgesamt nur $8 \%$ der Betriebe Teilspaltenböden eingesetzt haben. Der Anteil Betriebe mit Teilspaltenböden ist über alle drei Größenkategorien gleichmäßig verteilt.

Gar nicht oder sehr selten ( $<1 \%)$ wurden Zittern, Hecheln, die Bildung von Haufenlage und schwere Atmung dokumentiert. Andere Studien (Temple et al., 2011a; Temple et al., 2012a) bestätigen diese geringe Prävalenz. Nach Geers et al. (1990) hat die Stalltemperatur den größten Einfluss auf Zittern, Hecheln und die Bildung von Haufenlage. In einem konventionellen Haltungssystem mit vollklimatisierter Stalltemperatur und Luftführung treten die genannten Probleme kaum auf, so dass das Kriterium „Klimakomfort" als sehr gut bewertet wurde.

Der Score für das Kriterium „Bewegungsfreiheit“ betrug im Durchschnitt 72 von 100 erreichbaren Punkten. Die Punktzahl resultiert aus einem zu geringen Platzangebot. Unter Rückgriff auf die Tierschutz-Nutztierhaltungsverordnung (2006) waren $40 \%$ der Buchten überbelegt. Überbelegte Buchten wurden auf $92 \%$ der Betriebe dokumentiert. Auf allen Betrieben der größten Kategorie wurde mindestens eine überbelegte Bucht festgestellt. Eine zu hohe Besatzdichte hat einen negativen Einfluss auf das Vorkommen von Bursitis (Smith, 1993) und Wunden (Turner et al., 2000) sowie auf den Verschmutzungsgrad (Scott et al., 2007). Abgesehen von den möglichen negativen Effekten auf das Wohl der Tiere, ist die Nicht-Einhaltung der rechtlichen Vorgaben ein Verstoß gegen das Gesetz. 
Der Grundsatz "Gute Gesundheit" erzielte den schlechtesten Wert aller Grundsätze. Das dazugehörige Kriterium „Abwesenheit von Verletzungen“ bezieht unter anderem den Indikator Wunden ein. Mit einem Durchschnitt von $10,5 \%$ moderat verwundeten Schweinen über alle 60 Betriebe ist der Anteil hoch. Andere Studien (Courboulay et al., 2009; Temple et al., 2011a; Temple et al., 2012a; Temple et al., 2013) dokumentierten Inzidenzen von weniger als $2 \%$. Grundsätzlich gilt zu unterscheiden, ob die Wunden durch Mängel im Haltungssystem entstanden sind oder durch soziale Interaktionen. Es wurden keine signifikanten Unterschiede zwischen den Bestandsgrößen-Kategorien gefunden. Allerdings wurde festgestellt, dass bei Flüssigfütterungssystemen signifikant weniger Tiere verwundet waren. Ursächlich hierfür konnte ein besseres Tier-Fressplatz-Verhältnis sein, verbunden mit weniger Rangkämpfen (Botermans \& Svendsen, 2000). Andere Faktoren wie das Geschlecht (Fredriksen et al., 2008), Platzangebot (Turner et al., 2000) und das Alter werden in der Literatur als Einflussfaktoren auf den Verwundungsgrad diskutiert. Sie konnten in dieser Studie nicht detaillierter bzgl. des Einflusses der Bestandsgröße untersucht werden, da auf allen Betrieben Schweine verschiedenen Geschlechts und Alters gehalten sowie verschiedene Gruppengrößen gemanagt wurden.

Schwanzbeißen ist ein weiterer Indikator des Kriteriums „Abwesenheit von Verletzungen". Schwanzbeißen ist eines der bedeutendsten Tierschutzprobleme in der modernen Nutztierhaltung (Thays Sonoda et al., 2013). Es gilt als Haustierkrankheit, da dieses Verhalten fast ausschließlich bei domestizierten Tieren beobachtet werden kann (Moinard et al., 2003). Schwanzbeißen ist eine abnormale Verhaltensweise von Schweinen, welche multifaktorielle Ursachen hat (Moinard et al., 2003). Durch diese Verhaltensstörung wird die Gesundheit und das Wohlbefinden der Tiere beeinträchtigt (Thays Sonoda et al., 2013). Die Prävalenz ist in dieser Studie vergleichsweise gering. Ähnlich geringe Prävalenzen für das Vorkommen von Schwanzbeißen können andere Studien bestätigen (Temple et al., 2011a; 2011b; 2012b). Wobei zu berücksichtigen ist, dass alle Schweine kupierte Schwänze hatten. Nach einem Bericht der EFSA (2007) werden bei 90 - 95\% 
aller Mastschweine die Schwänze routinemäßig kupiert. Tatsächlich werden Schweine mit kupierten Schwänzen weniger stark gebissen (Sutherland et al., 2008). Allerdings verhindert das Kupieren nicht komplett das Schwanzbeißen (Moinard et al., 2003). Ausgehend von der hohen Anzahl routinemäßig kupierter Schweine scheinen die in Deutschland vorhandenen Haltungsbedingungen so gestaltet zu sein, dass die Tiere ohne kurative Eingriffe nicht gehalten werden können (Kastrieren, Schwänze kupieren). Bei der Diskussion um das Verzichten von Amputationen geht es v.a. darum, dass die Tiere nicht an die Haltungssysteme angepasst werden sollen, sondern die Haltungsbedingungen so gestaltet sein sollten, dass intakte Tiere mit innen gut zurechtkommen (WBA, 2015). Grundsätzlich gilt, dass es bei dem Verzicht auf das Schwänzekupieren Probleme in der Haltung und im Management wesentlich deutlicher und schneller erkennbar werden, was als wichtiges Alarmsignal verstanden werden kann (Keeling et al., 2012).

Zu dem Kriterium „Abwesenheit von Krankheiten“ gehören u.a. die Indikatoren „Hautzustand“ und das „Vorkommen von Brüchen und Durchfall“. Die Bewertung des Hautzustandes, als ergänzender Parameter zur Messung des Tierwohls, begründet sich nach Scott et al. (2009) darin, dass Entzündungen oder Verfärbungen auf systematische Erkrankungen, wie z.B. PDNS (Porcine Dermatitis Nephropathie Syndrome) oder auf lokale Hauterkrankungen wie bspw. Ohrnekrosen schließen lassen. Andere Faktoren wie lokale Entzündungen in Folge ungünstiger Stallböden sind ebenfalls als Ursache denkbar (Forkman \& Keeling, 2009; Temple et al., 2013). Nach Temple et al. (2013) ist die Ausprägung von Hautveränderungen sehr variabel. Der zeitliche Ablauf einer Krankheit ist nicht konstant. In der vorliegenden Studie zeigten die Tiere eine sehr niedrige Prävalenz des Indikators „leichte Hautveränderungen“ (bis zu $10 \%$ der Körperoberfläche ist verfärbt/entzündet). Schweine mit Brüchen oder lahme Tiere wurden ebenfalls kaum dokumentiert, was positiv zu bewerten ist. Verzerrender Faktor könnte ein gutes Gesundheitsmanagement sein. Dieses sieht vor, auffällige Tiere (z.B. lahmende Tiere, Schweine mit Brüchen) in eine Krankenbucht umzustallen. Tiere in Krankenbuchten werden nach Anweisung des Protokolls nicht in die Bewertung inkludiert und bleiben 
unberücksichtigt (Welfare Quality®, 2009). Diese Vorgehensweise ist sicherlich diskussionswürdig, da das Herausnehmen jener Tiere aus dem Gesamtbild datenverzerrend sein kann und womöglich vermindertes Tierwohl verschleiert. Die Präsenz von an Durchfall erkrankten Tieren war auf keinem der Betriebe zu erkennen. Die genannten Indikatoren des Kriteriums „Abwesenheit von Krankheiten" unterschieden sich in ihrem Vorkommen nicht zwischen den drei Bestandsgrößen-Kategorien.

Die Schlachtbefunde fließen ebenfalls in das Kriterium „Abwesenheit von Krankheiten" ein. Die Organbefunderhebung am Schlachthof stellt einen wichtigen Bestandteil der präventiven und therapeutischen Veterinärmedizin dar (Heinritzi et al., 2006). Schlachtbefunde können als ein Instrument für die Beratung des einzelnen Landwirts und zum Vergleich von Mastbeständen verwendet werden. Durch die Rückmeldung ist es dem Landwirt möglich, seinen Bestand einzuschätzen, Trends in der Entwicklung seiner Herdengesundheit zu erkennen und gezielte Maßnahmen zur Verbesserung zu ergreifen (Boeckel, 2008). Der Anteil veränderter Lungen war in kleinen Betrieben $(4,2 \%)$ tendenziell geringer als in mittleren $(11,7 \%)$ und großen Beständen (11,1\%). Andere Studien dokumentieren Inzidenzen von bis zu 50\% (Boeckel, 2008). Bezüglich der Grenzwerte des Welfare Quality ${ }^{\circledR}$ Protokolls erreichten auch die kleinen Bestände die vorgegebene Warnschwelle von > $2,7 \%$. Die mittleren und großen Bestände überschritten die Alarmschwelle (> $6 \%)$ deutlich. Grundsätzlich können Schlachtbefundsdaten eine geringe Wiederholbarkeit und Validität aufgrund unklarer Definitionen und Bewertungen (Schleicher et al., 2013) sowie jahreszeitlicher Einflüsse aufweisen (Stärk et al., 1998). Das Vorkommen von hustenden und niesenden Tieren sind zwei weitere Indikatoren des Kriteriums „Abwesenheit von Krankheiten“. Husten und Niesen wurden sehr selten auf den Betrieben dokumentiert. Der Grenzwert von 15 Hustern pro Schwein pro 5 min wurde nicht erreicht. Eine Korrelation zwischen dem Vorkommen von hustenden Tieren auf den Betrieben und den dokumentierten Lungenbefunden vom Schlachthof konnte nicht festgestellt werden. Die Mortalitätsrate betrug im Durchschnitt 2,5\% (0,9\% bis 5,2\%). Sie 
beläuft sich in großen Betrieben auf 2,7\% und war damit leicht höher als die vom Welfare Quality® Protokoll vorgegebene Warnschwelle von 2,6\%.

Bei dem Schwänzekupieren und Kastrieren der männlichen Tiere wurde kein Anästhetikum verwendet. Das Welfare Quality ${ }^{\circledR}$ Protokoll reagiert sehr sensitiv auf die genannten Managementpraktiken, sodass das Kriterium "Schmerzen“ deutlich weniger Punkte erreichte als die beiden bereits genannten Kriterien des Grundsatzes „Gute Gesundheit". Obwohl das Kupieren der Schwänze für den Moment schmerzhaft ist (Van Beirendonck et al., 2012), muss weiter untersucht werden, ob sich diese einmaligen Eingriffe auf das Wohlbefinden der Tiere im weiteren Mastverlauf auswirken. Das Mästen von Ebern scheint vorteilhafter zu sein, da das schmerzvolle und stressige Kastrieren der Ferkel entfällt (Rault et al., 2011). Die Ebermast kann im Vergleich zur Kastratenmast Verhaltensunterschiede hervorrufen, die zu Management- und Haltungsproblemen führen und damit das Tierwohl negativ beeinflussen können (Boyle \& Björklund, 2007). Dies wurde in der vorliegenden Studie nicht untersucht.

Der Grundsatz „Artgemäßes Verhalten“ erreichte im Schnitt nur einen geringen Score von knapp über 30 Punkten. Signifikante Unterschiede bezüglich der drei Bestandsgrößen-Kategorien konnten auf Ebene des Grundsatzes und auf Ebene der Kriterien und Indikatoren nicht abgesichert werden. Intensive Haltungssysteme werden oft hinsichtlich der mangelnden Ausübung von arttypischen Normalverhalten kritisiert (Van de Weerd \& Day, 2009). Die Beurteilung des Verhaltens beinhaltet eine höhere Subjektivität im Vergleich zu den anderen drei Grundsätzen (Temple et al., 2011b). Grundsätzlich sind neben den physiologischen v.a. die psychologischen Parameter wichtige Bestandteile des Tierwohls und müssen bei der Bewertung berücksichtigt werden (Duncan \& Petherick, 1991). In dieser Studie wurden vor allem Defizite beim Erkundungsverhalten (Kriterium „Sonstiges Verhalten“) und die schlechte Bewertung des „emotionalen“ Zustandes der Tiere dokumentiert. Der emotionale Zustand der Tiere ist schwierig zu messen (Boissy et al., 2007). In dieser Studie wurde dafür die qualitativen Verhaltensbeurteilung (QBA) 
durchgeführt (Rutherford et al., 2012; Phythiana et al., 2013). Um die Ergebnisse der QBA zu interpretieren, kann man die Millimeterscores der jeweiligen Adjektive vergleichen oder eine Faktorenanalyse (Principle Component Analyses - PCA) durchführen. Die Faktorenanalyse dient dazu, aus empirischen Beobachtungen vieler verschiedener Variablen (die 20 Adjektive der qualitativen Verhaltensbeobachtung), auf wenige zugrunde liegende Faktoren zu schließen. Die Faktorenanalyse verfolgt im Allgemeinen drei Ziele: Die Reduktion der Variablenanzahl (Zusammenfassung von Variablengruppen, in denen jeweils alle Variablen ähnliche Informationen besitzen, zu einem Faktor), die Ermittlung verlässlicher Messgrößen (der Faktor besitzt günstigere Eigenschaften als die einzelnen Variablen) und die analytische Zielsetzung (von den verschiedenen Variablen auf übergeordnete Faktoren schließen) (Backhaus et al., 2000). Beim Vergleich zwischen den PCAs der drei Bestandsgrößen-Kategorien ist auffällig, dass sich die kleine und die große Bestandsgrößen-Kategorie gegenüber der mittleren unterschieden haben. Auf Faktor 1 der kleinen und großen Kategorie laden hoch positive Werte für Adjektive, die aktives Verhalten mit positiver Stimmung beschreiben (aktiv, verspielt, lebendig). Faktor 1 der mittleren Kategorie wird eher durch Adjektive mit einer negativen Stimmung (furchtvoll, angespannt, frustriert) beschrieben. Die Unterschiede können weder durch das Haltungssystem noch durch das Management erklärt werden, da sich die 60 Betriebe diesbezüglich kaum unterscheiden. In der Literatur wird die eigene tagesabhängige Stimmung als Ursache für Unterschiede zwischen den PCAs beschrieben. Der Beobachter lässt sich von seinen Gefühlen leiten. Dies ist ein oft beschriebenes Problem bei der subjektiven Verhaltensbeobachtung (Tuyttens et al., 2009). Die individuelle Einstellung/Ausbildung zu der Tierhaltung ist ebenfalls ein wichtiger Gesichtspunkt, der die Auswertung erschwert. Da alle 60 Betriebe von ein und demselben Beobachter besucht wurden, können interobserver Effekte wie z.B. eine unterschiedliche Verwendung der visuellen Analog-Scala (Skala zur Messung subjektiver Einstellungen) als Ursache ausgeschlossen werden. Demnach sind die Unterschiede zwischen den Bestandsgrößen-Kategorien nicht wirklich zu erklären. Zu berücksichtigen ist, dass keiner der Faktoren mehr 
als $39 \%$ der Varianz der verschiedenen PCAs erklären kann. Somit sind die Unterschiede zwischen den Betrieben bezüglich der qualitativen Verhaltensbeobachtung eher zu vernachlässigen.

Defizite im Erkundungsverhalten in konventionellen Haltungssystem wurden bereits von Temple et al. (2011b) beschrieben. Die Autoren haben darüber hinaus festgestellt, dass eine Zunahme von negativen Sozialverhalten mit einer Abnahme vom Erkundungsverhalten einhergeht. Dieser Zusammenhang kann in der vorliegenden Studie nicht bestätigt werden. Obwohl alle Buchten mit Spielmaterial ausgestattet waren, haben sich nur wenige Schweine mit diesem beschäftigt (unter $3 \%$ ). Dies lässt schlussfolgern, dass das in konventionellen Haltungssystemen üblicherweise eingesetzte Beschäftigungsmaterial (Kugeln, Kunststoffelemente) nicht ausreichend interessant für die Schweine zu sein scheint (Studnitz et al., 2007). Das Auftreten sowie das Verhältnis vom Erkunden der Bucht und die Beschäftigung mit dem Spielmaterial zeigen, dass die Ausübung von arttypischen Verhaltensweisen unter konventionellen Bedingungen nicht ausreichend gelebt werden kann (Temple et al., 2011b). Dieser Aspekt wird vor allem deutlich, wenn man Schweine in extensiven und intensiven Haltungsbedingungen beobachtet und das Erkundungsverhalten vergleicht.

\subsection{Zusammenhang zwischen Gruppengröße und Tierwohl}

Die Gruppengröße beschreibt die Anzahl Schweine pro Bucht bei konstantem Platzangebot pro Tier. Die Gruppengröße variierte in dieser Studie zwischen 10 und 350 Schweinen pro Bucht. Um den Einfluss der Gruppengröße aufs Tierwohl betrachten zu können, wurden die drei Gruppengrößen-Kategorien klein (< 15 Schweine/Bucht), mittel (15-30 Schweine/Bucht) und groß ( $>30$ Schweine/Bucht) definiert. Demzufolge ist die Spannweite in der großen Gruppengrößen-Kategorie deutlich weiter als in den beiden kleineren Gruppengrößen-Kategorien. Dies muss bei der Interpretation der Ergebnisse berücksichtigt werden. 
Auf Grund der hohen Anzahl Buchten, in denen Schweine unterschiedlichen Geschlechts zusammen aufgestallt wurden, konnte das Geschlecht im vorliegenden Versuch mit bestimmten Verhaltensweisen und unterschiedlichen Ausprägungen von Tierwohl-Indikatoren nicht in Verbindung gebracht werden. Andere mögliche Faktoren wie die Genetik der Schweine sowie das Lüftungssystem konnten ebenfalls nicht berücksichtigt werden.

Die Indikatoren moderate Bursitis, moderate Wunden und moderate Verschmutzung waren die drei am häufigsten vorkommenden Parameter in dieser Studie. Darüber hinaus werden Bursitis und Verschmutzung als die sensitivsten Indikatoren des Welfare Quality ${ }^{\circledR}$ Protokolls betrachtet (Temple et al., 2011a). Ihre Prävalenz wurde deshalb genauer in Abhängigkeit von der Gruppengröße untersucht. Mögliche Ursachen und Einflussfaktoren im Zusammenhang mit den Indikatoren werden im Folgenden nicht mehr im Detail behandelt. Diese wurde bereits im vorigen Kapitel (Kapitel 6.2) detailliert beschrieben.

Die Gruppengröße hat keinen signifikanten Einfluss auf das Vorkommen von moderater Bursitis. Ein signifikanten Effekt auf das Auftreten von moderater Verschmutzung $(p<0,05)$ wurde dagegen beobachtet: Am häufigsten konnten moderat verdreckte Schweine in großen Gruppen dokumentiert werden. Wie beschrieben wirken sich sowohl Flüssigfütterungssysteme als auch Teilspaltenböden verstärkend auf den Verschmutzungsgrad der Tiere aus. Allerdings lässt sich der beschriebene Zusammenhang nicht durch das Fütterungssystem und die Art des Bodens erklären. In kleinen Gruppen wurden relativ mehr Flüssigfütterungssysteme eingesetzt als in großen Gruppen. Darüber hinaus war die Verwendung von Teilspaltenböden in Großgruppen seltener.

Moderat verwundete Tiere wurden in der größten Gruppengrößen-Kategorie am häufigsten dokumentiert $(p<0,05)$. Den gleichen Zusammenhang konnten Rodenburg \& Koene (2007) sowie McGlone \& Newby (1994) feststellen. Die Anzahl möglicher Rangkämpfe zwischen den Schweinen nimmt proportional mit steigender Gruppengröße zu. Demnach führen größere Gruppen zu mehr verletzten Tieren bedingt durch mehr Aggressionen, Angst und Stress. In dieser 
Studie wurde negatives Sozialverhalten ebenfalls häufiger in der großen als in der mittleren und kleinen Gruppengrößen-Kategorie beobachtet.

Studien, die sich explizit mit dem Zusammenhang Gruppengröße und Erkundungs- und Sozialverhalten von Schweinen beschäftigt haben, gibt es kaum, auch wenn die Ausübung des Normalverhaltens zunehmend an Bedeutung gewinnt (Van de Weerd \& Day, 2009; WBA, 2015). Im WQP haben die Indikatoren zur Beurteilung des Tierverhaltens einen vergleichsweise großen Anteil und wurden entsprechend in dieser Studie ausführlich betrachtet. Wie bereits beschrieben, wurde in der großen Gruppengrößen-Kategorie mehr negatives Sozialverhalten dokumentiert, was auf Defizite bezüglich des Wohls der Schweine hinweist. Ursächlich hierfür können vermehrt Auseinandersetzungen um wichtige Ressourcen wie Futter und Wasser sein. Allerdings sind die gezeigte Frequenzen von negativen Sozialverhalten vergleichsweise gering (Temple et al., 2011b). Positive Verhaltensweisen (soziales Lecken) wurden deutlich häufiger beobachtet als negative Verhaltensweise, wobei soziale Interaktionen positiv beginnen und negativ enden können. So kann Schwanzbeißen zunächst mit einem harmlosen Lecken am Schwanz des anderen Schweines beginnen, aber mit einem schmerzhaften Beißen enden (Taylor et al., 2010). Daraus lässt sich folgern, dass ein hohes $\mathrm{Maß}$ an positiver sozialer Aktivität nicht zwingend mit einer positiven Stimmung des Tieres verbunden sein muss (Boissy et al., 2007).

Die Bewertung der Mensch-Tier-Beziehung wurde auf jedem Betrieb in 10 Buchten durchgeführt. Insgesamt wurde in $14,5 \%$ der Buchten eine schlechte Mensch-Tier-Beziehung beobachtet. Nach Temple et al. (2011a) hat ein Betrieb Defizite bezüglich der Mensch-Tier-Beziehung, wenn in mehr als $30 \%$ der Buchten eine schlechte Mensch-Tier-Beziehung festgestellt wird. In dieser Studie wurde auf 8 von 60 Betrieben in mindestens 30\% der Buchten eine schlechte Mensch-Tier-Beziehung dokumentiert. In großen Gruppen wurde mit einer Häufigkeit von etwa $6 \%$ eine schlechte Mensch-Tier-Beziehung festgestellt. Im Vergleich $\mathrm{zu}$ den großen Gruppen ist die Eintrittswahrscheinlichkeit für eine schlechte Mensch-Tier-Beziehung in der kleinen Gruppengrößen-Kategorie signifikant höher. Nach Erhard et al. (1999) 
können ungewohnte Ereignisse oder Bedrohungen unterschiedliche Reaktionen beim Tier auslösen. Forkman et al. (2007) und Dalmau et al. (2009) konnten dokumentieren, dass die Ängstlichkeit bei Schweinen mit zunehmendem Alter sinkt. Es lässt sich kein eindeutiger Alterseffekt in dieser Untersuchung erkennen, wobei relativ hohe Streuungen vorliegen. Eine hohe Streuung wurde auch in der Studie von Temple et al. (2011a) festgestellt. Schweine, die in Systemen gehalten werden (z.B. extensiv), bei denen auf Grund der Bauweise regelmäßiger Kontakt und damit Gewöhnung zum Menschen verwehrt bleiben, könnten bei Kontakt ängstlicher sein und das Wohlergehen dadurch vermindert sein (Erhard et al., 1999). Dieser Ansatz könnte u.a. die bessere Mensch-TierBeziehung in der großen Gruppengrößen-Kategorie erklären. Der Landwirt muss bei seinen täglichen Routinekontrollen durch die großen Gruppen (> 30 Schweine/Bucht) durchgehen. Damit sind die Schweine mit dem menschlichen Kontakt vertraut. Grundsätzlich beeinflusst die Art des Umgangs des Stallpersonals mit den Tieren erheblich die Reaktion beim Tier-Mensch-Kontakt. Um für das Tier stressvolle Situationen zu vermeiden, sollte der Umgang gegenüber dem Tier positiv ausfallen, unterstützt durch Gewöhnungs- und Trainingsphasen (Forkman et al., 2007; Courboulay et al., 2009).

Wie bereits im vorigen Kapitel beschrieben, waren $40 \%$ der untersuchten 600 Buchten überbelegt. Ein signifikanter Effekt der Überbelegung auf verschiedenen Tierwohl-Indikatoren konnte nicht festgestellt werden. Es wurden nur Tendenzen beobachtet, die darauf hindeuten, dass das Tierwohl bei Überbelegung negativ beeinflusst wird.

\subsection{Schlussfolgerungen}

Die Auswahl der Betriebe über die Beratungsringe und die Einteilung in die drei Bestandsgrößen- sowie Gruppengrößen Kategorien sind limitierende Faktoren bezüglich der generellen Aussagekraft dieser Studie. Gleichzeitig ist diese Untersuchung eine der ersten, die sich mit dem Zusammenhang zwischen Bestands- und Gruppengrößen sowie dem Tierwohlniveau von konventionellen Schweinemastbetrieben beschäftigt. 
Aus den Ergebnissen dieser Arbeit können folgende Schlussfolgerungen abgeleitet werden:

- Bezüglich der Einstufung der Betriebe hinsichtlich ihres Tierwohl-Niveaus ist die Gesamtsituation nach dem Welfare Quality ${ }^{\circledR}$ Protokoll als unbefriedigend einzustufen.

- Der Gesamtscore und die beiden Grundsätze Verhalten und Gesundheit erreichten nach dem Welfare Quality ${ }^{\circledR}$ Protokoll ein kritisch niedriges Niveau.

- Nicht akzeptabel sind der hohe Anteil überbelegter Buchten sowie die teilweise gravierenden Mängel in der Wasserversorgung. Hintergründe und Ursache dieser Verstöße konnten nicht untersucht wurden, wobei sicherlich ein höheres Maß an Kontrollen hilfreich wäre, um diese Missstände zu beheben.

Bei der Interpretation der Ergebnisse muss die Nicht-Einhaltung der Richtlinien der Nutztierhaltungsverordnung berücksichtigt werden. Es kann nicht ausgeschlossen werden, dass bei den Untersuchungen des Einflusses der Bestandsgröße bzw. Gruppengröße auf das Tierwohl bei Einhaltung der Vorgaben der Verordnung womöglich andere Ergebnisse herausgekommen wären.

- Im Mittel waren fast 35\% der Schweine von moderater Bursitis betroffen. Die Haltung auf Betonspaltenböden ist als Hauptursache zu diskutieren und muss demnach kritisch hinterfragt werden.

- Die teilweise sehr hohen Verschmutzungs- und Verwundungsgrade der Schweine waren erheblich. Sie deuten auf Defizite bezüglich des Mästens von Schweinen in konventionellen Haltungssystemen hin.

- Grundsätzlich positiv zu bewerten sind die geringen Inzidenzen einiger Indikatoren (zittern, hecheln, lahme Tiere und Schweine mit veränderter Hautkondition). 
Bezüglich des Zusammenhanges zwischen der Größe eines schweinehaltenden Betriebes und den Ergebnissen des Welfare Quality ${ }^{\circledR}$ Protokolls konnte kein direkter Zusammenhang festgestellt werden. Die Bestandsgröße hatte keinen Effekt auf die Ausprägung des Gesamtscores, der 4 Grundsätze und 12 Kriterien. Hinsichtlich der Indikatoren wurden tendenziell weniger Schweine mit veränderten Lungen auf kleinen Betrieben dokumentiert. Selbiges wurde für den Verschmutzungsgrad der Tiere festgestellt. Grundsätzlich ließen sich sowohl Betriebe mit guten Bewertungen, als auch Betriebe mit schlechten Bewertungen in jeder der drei BestandsgrößenKategorien nachweisen. Eine hohe Anzahl an Mastschweinen pro Bestand deutet demnach nicht automatisch auf eine niedrige Tierwohlbewertung hin. Damit ist die Bestandsgröße als Indikator für unzureichendes Wohlergehen nicht geeignet.

Hinsichtlich des Zusammenhangs zwischen den drei GruppengrößenKategorien und ausgewählten Indikatoren des Welfare Quality ${ }^{\circledR}$ Protokolls wurden Unterschiede festgestellt. Mit zunehmender Gruppengröße waren die Schweine in den großen Buchten stärker verdreckt. Der Anteil moderat verwundeter Tiere nahm ebenfalls mit steigender Gruppengröße signifikant zu. Allerdings konnte in großen Gruppen häufiger eine gute Mensch-TierBeziehung beobachtet werden. Demnach war keine der untersuchten Gruppengrößen-Kategorien im Hinblick auf die Indikatoren des Welfare Quality® Protokolls konsistent überlegen.

Vielmehr scheint die Bedeutung der Gruppengröße, ebenso wie die der Bestandsgröße, hinsichtlich des Wohls der Tiere überschätzt zu sein. Stattdessen sollten in der Diskussion um Tierschutz und Tierwohl andere Faktoren wie z.B. das Management, das Haltungssystem und die Ausbildung und Einstellung der tierbetreuenden Person in den Fokus der der Untersuchungen genommen werden, um das Tierwohl auf den Betrieben nachhaltig zu verbessern. 


\section{Literaturverzeichnis}

Backhaus K., Erichson B., Plinke W. \& Weiber R. 2000. Multivariate Analysemethoden: Eine anwendungsorientierte Einführung. 9 Springer Verlag, 1-55

Boeckel V. 2008. Untersuchungen zur quantitativen Bewertung der Tiergesundheit von Schweinebeständen - Dissertation; Hannover, Germany

Boissy A., Manteuffel G., Jensen M.B., Moe R.O., Spruijt B., Keeling L.J., Winckler C., Forkman B., Dimitrov I., Langbein J., Bakken M., Veissier I. \& Aubert A. 2007. Assessment of positive emotions in animals to improve their welfare. Physiology and Behavior 22: 375-397

Botermans J.A.M. \& Svendsen J. 2000. Effect of feeding environment on performance, injuries and behaviour in growing-finishing pigs: Groupbased studies. Acta Agriculturae Scandinavica 50: 237-249

Boyle L.A. \& Björklund L. 2007. Effects of fattening boars in mixed or single sex groups and split marketing on pig welfare. Animal Welfare 16: 259-262

Courboulay V., Eugène A. \& Delarue E. 2009. Welfare assessment in 82 pig farms: effect of animal age and floor type on behaviour and injuries in fattening pigs. Animal Welfare 18: 515-521

Dalmau A., Fabrega E. \& Velarde A. 2009. Fear assessment in pigs exposed to a novel object test. Applied Animal Behaviour Science 117: 173-180

Day J.E.L., Kyriazakis I. \& Lawrence A.B. 1995. The effect of food deprivation on the expression of foraging and exploratory behaviour in the growing pig. Applied Animal Behaviour Science 42: 193-206

Duncan I.J. \& Petherick J. 1991. The implications of cognitive processes for animal welfare. Journal of Animal Science 69: 5017-5022 
EFSA 2007. The risks associated with tail biting in pigs and possible means to reduce the need for tail docking considering the different housing and husbandry systems. The EFSA Journal 611: 1-13

Erhard H.W., MendI M. \& Christiansen S.B. 1999. Individual differences in tonic immobility may reflect behavioural strategies. Applied Animal Behaviour Science 64: 31-46

Forkman B., Boissy A., Meunier-Salan M.C., Canali E. \& Jones R.B. 2007. A critical review of fear tests used on cattle, pigs, sheep, poultry and horses. Physiology and Behavior 92: 340-374

Forkman B. \& Keeling L. 2009. Assessment of Animal Welfare Measures for Sows, Piglets and Fattening Pigs Cardiff University Cardiff, United Kingdom,

Fredriksen B., Lium B.M., Marka C.H., Mosveen B. \& Nafstad O. 2008. Entire male pigs in farrow-to-finish pens: Effects on animal welfare. Applied Animal Behaviour Science 110: 258-268

Geers R., Goedseels V., Parduyns G., Nijns P. \& Wouters P. 1990. Influence of floor type and surface temperature on the thermoregulatory behaviour of growing pigs. Journal of Agricultural Engineering Research 45: 149-156

Gillman C.E., KilBride A.L., Ossent P. \& Green L.E. 2008. A cross-sectional study of the prevalence and associated risk factors for bursitis in weaner, grower and finisher pigs from 93 commercial farms in England. Preventive Veterinary Medicine 83: 308-322

Heinritzi K., Gindele H., Reiner G. \& Schnurrbusch U. 2006. Schweinekrankheiten. Eugen Ulmer KG, Stuttgart, Germany

Kamphues J. \& Schulz I. 2002. Field relevant aspects of the water supply in food producing animals. Übersichten zur Tierernährung - Survey of Animal Nutrition 30: 65-107 
Kayser M., Schlieker K. \& Spiller A. 2012. Die Wahrnehmung des Begriffs "Massentierhaltung" aus Sicht der Gesellschaft. Berichte über Landwirtschaft 90: 417-427

Keeling L., Wallenbeck A., Larsen A. \& Holmgren N. 2012. Scoring tail damage in pigs: an evaluation based on recordings at Swedish slaughterhouses. Acta Veterinaria Scandinavica 54: 32-41

KilBride A.L., Gillman C.E., Ossent P. \& Green L.E. 2008. A cross-sectional study of the prevalence and associated risk factors for capped hock and the associations with bursitis in weaner, grower and finisher pigs from 93 commercial farms in England. Preventive Veterinary Medicine 83: 272284

Knage-Rasmussen K.M., Sørensen J.T., Rousing T. \& Houe H. 2013. No association between sow and slaughter pig herd size and animal welfare index based on on-farm welfare assessment. „Does big mean bad? The science behind large scale production". Roslin Institut, University Edinburgh United Kingdom.

Lyons C.A.P., Bruce J.M., Fowler V.R. \& English P.R. 1995. A comparison of productivity and welfare of growing pigs in four intensive systems. Livestock Production Science 43: 265-274

McGlone J. \& Newby B. 1994. Space requirements for finishing pigs in confinement: behavior and performance while group size and space vary. Applied Animal Behaviour Science 39: 331-338

Moinard C., Mendl M., Nicol C.J. \& Green L.E. 2003. A case control study of onfarm risk factors for tail biting in pigs. Applied Animal Behaviour Science 81: $333-355$ 
Otten D., Annas E. \& Van den Weghe H.F.A. 2013. The application of animal welfare standards in intensive production systems using the assessment protocols of Welfare Quality®: Fattening pig husbandry in Northwest Germany. International Journal of Livestock Production 4: 49-59

Phythiana C., Michalopoulou E., Duncana J. \& Wemelsfelder F. 2013. Interobserver reliability of Qualitative Behavioural Assessments of sheep. Applied Animal Behaviour Science 144: 73-79

Rault J.-L., Lay Jr D.C. \& Marchant-Forde J.N. 2011. Castration induced pain in pigs and other livestock. Applied Animal Behaviour Science 135: 214225

Rodenburg T.B. \& Koene P. 2007. The impact of group size on damaging behaviours, aggression, fear and stress in farm animals. Applied Animal Behaviour Science 103: 205-214

Rutherford K.M.D., Donald R.D., Lawrence A.B. \& Wemelsfelder F.o. 2012. Qualitative Behavioural Assessment of emotionality in pigs. Applied Animal Behaviour Science 139: 218-224

Schleicher C., Scheriau S., Kopacka I., Wanda S., Hofrichter J. \& Köfer J. 2013. Analysis of the variation in meat inspection of pigs using variance partitioning. Preventive Veterinary Medicine 111: 278-285

Scott K., Chennells D.J., Campbell F.M., Hunt B., Armstrong D., Taylor L., Gill B.P. \& Edwards S.A. 2006. The welfare of finishing pigs in two contrasting housing systems: Fully-slatted versus straw-bedded accommodation. Livestock Science 103: 104-115

Scott K., Taylor L., Gill B.P. \& Edwards S.A. 2007. Influence of different types of environmental enrichment on the behaviour of finishing pigs in two different housing systems: 2. Ratio of pigs to enrichment. Applied Animal Behaviour Science 105: 51-58 
Scott K., Binnendijk G.P., Edwards S.A., Guy J.H., Kiezebrink M.C. \& Vermeer H.M. 2009. Preliminary evaluation of a prototype welfare monitoring system for sows and piglets (Welfare Quality project). Animal Welfare 18: $441-449$

Smith W.J. 1993: A study of adventitious bursitis of the pig hock. Doctor of Veterinary Medicine and Surgery. University of Edinburgh, United Kingdom, Edinburgh, United Kingdom.

Stärk K.D.C., Pfeiffer D.U. \& Morris R.S. 1998. Risk factors for respiratory diseases in New Zealand pig herds. New Zealand Veterinary Journal 46: 3-10

Statistisches Bundesamt 2014. Viehhaltung der Betriebe. Landwirtschaftszählung. Agrarstrukturerhebung. Fachserie 3 Reihe 2.1.3. Statistisches Bundesamt (Destatis), Wiesbaden.

Studnitz M., Jensen M.B. \& Pedersen L.J. 2007. Why do pigs root and in what will they root?: A review on the exploratory behaviour of pigs in relation to environmental enrichment. Applied Animal Behaviour Science 107: 183197

Sutherland M.A., Bryer P.J., Krebs N. \& McGlone J.J. 2008. Tail docking in pigs: acute physiological and behavioural responses. Animal 2: 292-297

Taylor N.R., Main D.C.J., Mendl M. \& Edwards S.A. 2010. Tail-biting: A new perspective. The Veterinary Journal 186: 137-147

Temple D., Dalmau A., Ruiz de la Torre J., Manteca X. \& Velarde A. 2011a. Application of the Welfare Quality ${ }^{\circledR}$ protocol to assess growing pigs kept under intensive conditions in Spain. Journal of Veterinary Behaviour: Clinical Applications and Research 6: 138-149 
Temple D., Manteca X., Velarde A. \& Dalmau A. 2011b. Assessment of animal welfare through behavioural parameters in Iberian pigs in intensive and extensive conditions. Applied Animal Behaviour Science 131: 29-39

Temple D., Courboulay V., Manteca X., Velarde A. \& Dalmau A. 2012a. The welfare of growing pigs in five different production systems: assessment of feeding and housing. Animal 6: 656-667

Temple D., Courboulay V., Velarde A., Dalmau A. \& Manteca X. 2012b. The welfare of growing pigs in five different production systems in France and Spain: assessment of health. Animal Welfare 21: 257-271

Temple D., Manteca X., Dalmau A. \& Velarde A. 2013. Assessment of testretest reliability of animal-based measures on growing pig farms. Livestock Science 151: 35-45

Thays Sonoda L., Fels M., Oczak M., Vranken E., Ismayilova G., Guarino M., Viazzi S., Bahr C., Berckmans D. \& Hartung J. 2013. Tail biting in pigs causes and management intervention strategies to reduce the behavioural disorder. A review. Berliner und Münchener Tierärztliche Wochenschrift 126: 104-112

Tierschutz-Nutztierhaltungsverordnung 2006. Verordnung zum Schutz landwirtschaftlicher Nutztiere und anderer zur Erzeugung tierischer Produkte gehaltener Tiere bei ihrer Haltung (TierschutzNutztierhaltungsverordnung - TierSchNutztV) in der Fassung der Bekanntmachung vom 22. August 2006, Bundesgesetzblatt Jahrgang 2006 Teil I Nr. 41, ausgegeben zu Bonn, Germany, am 31. August 2006, (BGBI. I S. 2053).

Turner S.P., Ewen M., Rooke J.A. \& Edwards S.A. 2000. The effect of space allowance on performance, aggression and immune competence of growing pigs housed on straw deep-litter at different group sizes. Livestock Production Science 66: 47-55 
Tuyttens F., Sprenger M., Van Nuffel A., Maertens W. \& Van Dongen S. 2009. Reliability of categorical versus continuous scoring of welfare indicators: lameness in cows as a case study. Animal Welfare 18: 399-405

Van Beirendonck S., Driessen B., Verbeke G., Permentier L., van de Perre V. \& Geers R. 2012. Improving survival, growth rate, and animal welfare in piglets by avoiding teeth shortening and tail docking. Journal of Veterinary Behavior: Clinical Applications and Research 7: 88-93

Van de Weerd H.A. \& Day J.E.L. 2009. A review of environmental enrichment for pigs housed in intensive housing systems. Applied Animal Behaviour Science 116: 1-20

WBA 2015. Wissenschaftlicher Beirat für Agrarpolitik: Wege zu einer gesellschaftlich akzeptierten Nutztierhaltung - Gutachten des Wissenschaftlicher Beirats für Agrarpolitik beim BMEL. Grethe $H_{\text {., }}$ Christen O., Balmann A., Baushus J., Birner R., Bokelmann W., Gauly M., Knierim U., Latacz-Lohmann U., Nieberg H., Quaim M., Spiller A., Taube F., Weingarten P., Martinez J., Tenhagen B. u. Entenmann S., Berlin. 89-119

Welfare Quality ${ }^{\circledR}$ 2009. Welfare Quality ${ }^{\circledR}$ assessment protocol for pigs (sow and piglets, growing and finishing pigs). Welfare Quality® Consortium, Lelystad, The Netherlands 


\section{Danksagung}

Diese Doktorarbeit entstand im Rahmen des Promotionsprogramms „Animal Welfare in Intensive Livestock Production Systems - Tierhaltung im Spannungsfeld von Tierwohl, Ökonomie und Gesellschaft". Sie wurde gefördert durch ein Promotionsstipendium vom Ministerium für Wissenschaft und Kultur des Landes Niedersachsen. Für diese Unterstützung und die damit verbundene Möglichkeit zur Promotion möchte ich mich sehr herzlich bedanken.

Prof. Dr. Dr. Matthias Gauly möchte ich für die Überlassung des Themas, die konstruktive Unterstützung sowie für die fachlichen Hinweise während der Anfertigung meiner Arbeit danken. Ein besonderer Dank gilt zudem Dr. Christian Lambertz für die jederzeit gewährte Beratung zu unterschiedlichsten Fragen der Arbeit. Ich danke beiden sehr für ihre stets offenen Ohren aus dem fernen Bozen, ihr Vertrauen in meine Ideen und die Aufforderung zu kritischen Nachfragen.

Prof. Dr. Achim Spiller und Prof. Dr. Nicole Kemper danke ich für die Bereitschaft, meine Disputation zu prüfen.

Dr. Karl-Heinz Tölle von der ISN e.V. sowie den Leitern der verschiedenen Beratungsringen Dr. Conrad Welp, Dr. Jörg Bauer, Martin Knees, Georg Freisfeld und Gert Stelling danke ich für ihre Unterstützung bei der Betriebsakquise. Vor allem danke ich den beteiligten Landwirten, die mich bereitwillig in ihre Betriebe haben blicken und viele wertvolle Erfahrungen haben sammeln lassen. Ohne diese Datengrundlage hätte diese Arbeit nicht entstehen können. Besonders Irena Czycholl von der CAU Kiel hat mein kritisches Auge geschärft und mir konstruktiv beratend zur Seite gestanden, wofür ich ihr herzlich danke!

Der Arbeitsgruppe „Produktionssystem der Nutztiere“ danke ich sehr für die herzliche Aufnahme, die aufbauenden Worte, die große Hilfsbereitschaft und nicht zuletzt zahlreiche fröhliche Stunden. Anna Stölzl, Stefanie Ammer, Daniel Gieseke, Erwin Tönges, Birgit Sohnrey, Andrea Armbrecht, Wolfgang Holtz und 
Burchard Möllers haben dafür gesorgt, dass die Promotionszeit nicht nur Arbeit, sondern auch ein Vergnügen war. Meine beiden Mitdoktorandinnen Steffi und Anna haben den größten Anteil daran, dass ich immer wieder gerne an die Zeit in Göttingen zurückdenken werde.

All meinen Freundinnen und Freunden, insbesondere Henrike Hennies, Donata Mylius, Jenny Franz, Tina Knippscheer, Anna von Harling, Gesa Busch, Martina Abel und Matthias Rickes möchte ich für ihren Zuspruch und vor allem die erfrischende Ablenkung während meiner Promotionszeit danken. Mein besonderer Dank gilt Gundi Stinus für die vielen Erlebnisse hoch zu Ross. Den Huberten danke ich für die heiteren Mittwochabende und unvergesslichen Jagderlebnisse.

Mein größter Dank gilt aber meiner Familie - meinen Eltern Katja und Christoph Meyer-Hamme sowie meinen Geschwistern Johanna, Alexa, Friedrich und Charlotte. Mein Dank für Euren immer bedingungslosen familiären Rückhalt und für Eure Unterstützung in jeder Lebenslage geht weit über diese Arbeit hinaus. 


\section{Eidesstattliche Erklärung}

1. Hiermit erkläre ich, dass diese Arbeit weder in gleicher noch in ähnlicher Form bereits anderen Prüfungsbehörden vorgelegen hat.

Weiter erkläre ich, dass ich mich an keiner anderen Hochschule um einen Doktorgrad beworben habe.

Göttingen, den

(Unterschrift)

2. Hiermit erkläre ich eidesstattlich, dass diese Dissertation selbständig und ohne unerlaubte Hilfe angefertigt wurde.

Göttingen, den

(Unterschrift) 


\section{Curriculum Vitae}

Name

Geburtsdatum

Geburtsort

Staatsangehörigkeit

\section{Ausbildung}

Seit $02 / 2013$

$10 / 2009-11 / 2011$

$10 / 2006-07 / 2009$

08/1996-06/2005
Sophie Elise Katharina Meyer-Hamme 08.08.1986

Sulingen, Deutschland

deutsch

\section{Promotionsstudium}

Georg-August-Universität Göttingen, Department für Nutztierwissenschaften, Produktionssysteme der Nutztiere Promotionsprogramm "Animal Welfare in Intensive Livestock Production Systems" gefördert vom Niedersächsischen Ministerium für Wissenschaft und Kultur

Studium, Master of Science Agrarwissenschaften (Schwerpunkt: Nutztierwissenschaften) an der Georg-August-Universität Göttingen Masterabschlussnote: 1,4

Studium, Bachelor of Science Agrarwissenschaften (Schwerpunkt: Nutztierwissenschaften) an der Georg-August-Universität Göttingen Bachelorabschlussnote: 1,8

Hochschulreife

Abitur am Städtischen Gymnasium

Petershagen/Weser (Abschlussnote: 2,3)

\section{Praktische Erfahrungen}

07/2012 - 12/2012 Hochschulpraktikum im Bundesamt für Veterinärwesen, Zentrum für tiergerechte Haltung: Wiederkäuer und Schweine, Tänikon, Schweiz
$03 / 2012-04 / 2012$
Praktikum auf zwei Milchviehbetrieben in Neuseeland (Plantation Road Dairies Ltd, Waipawa und Galloway Enterprises Ltd, Takapau)
07/2010 - 09/2010 Praktikum bei Topigs (Hoppenbrock Tierzucht $\mathrm{GmbH}$ ), Melle 


$\begin{array}{ll}08 / 2009-10 / 2009 & \text { Praktikum bei der VzF GmbH, Uelzen } \\ 02 / 2009-05 / 2009 & \begin{array}{l}\text { Praktikum und Bachelorarbeit im Institut für } \\ \text { Tierernährung, FLI Braunschweig }\end{array} \\ 08 / 2008-09 / 2008 & \begin{array}{l}\text { Praktikum am Scottish Agriculture College, Hill and } \\ \text { Mountain Research Centre, Crianlarich, Schottland }\end{array} \\ 08 / 2005-07 / 2006 & \begin{array}{l}\text { Einjähriges Praktikum im Landwirtschaftszentrum } \\ \text { Haus Düsse, Soest (Praktikantenprüfung: 2,1) }\end{array}\end{array}$

\section{Auslandserfahrungen}

12/2011 - 04/2012 Work \& Travel in Neuseeland

08/2008 - 09/2008 Praktikum am Scottish Agriculture College, Hill and Mountain Research Centre, Crianlarich, Scotland

\section{Publikationen}

Bericht, Fachzeitung:

Meyer-Hamme, Sophie / Lambertz, Christian / Gauly, Matthias (2016): Does group size have an impact on welfare indicators in fattening pigs? Animal 10, S. 142-149

Meyer-Hamme, Sophie / Gazzarin, Christian / Kutzer, Tanja (2013):

Vom Nutzen der Streicheleinheiten: Eine gute Mensch-Tier-Beziehung. UFA-Revue, S. 18-19

Konferenz, Präsentation:

Meyer-Hamme, Sophie / Lambertz, Christian / Gauly, Matthias:

Hat die Bestandsgröße von konventionellen Schweinemastbetrieben

Einfluss auf das Tierwohl?

Vortragstagung der DGfZ und GfT, 16./17. September 2015, Berlin

Meyer-Hamme, Sophie / Lambertz, Christian / Gauly, Matthias:

Does group size have an impact on welfare indicators in fattening pigs?

EAAP - European Federation of Animal Science; 31.08.2015 - 03.09.2015, Warschau, Polen 
